Historic, Archive Document

Do not assume content reflects current scientific knowledge, policies, or practices. 



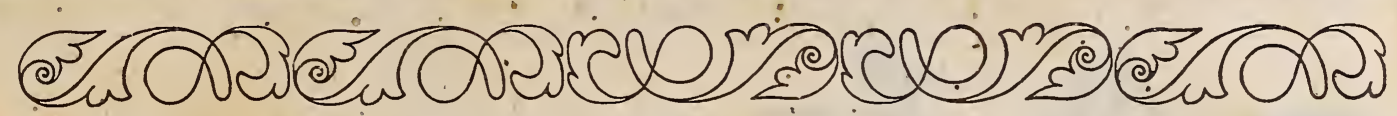

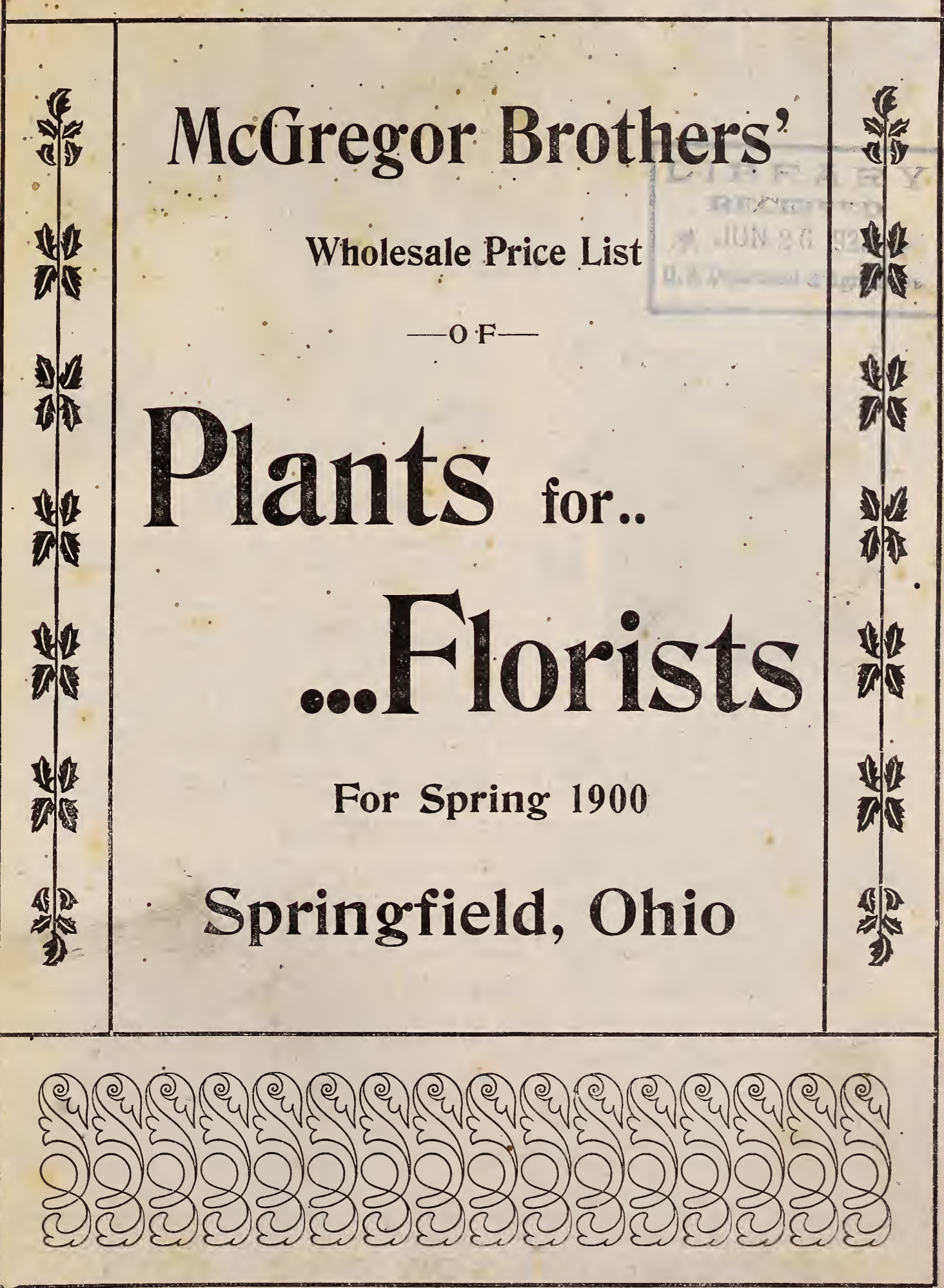




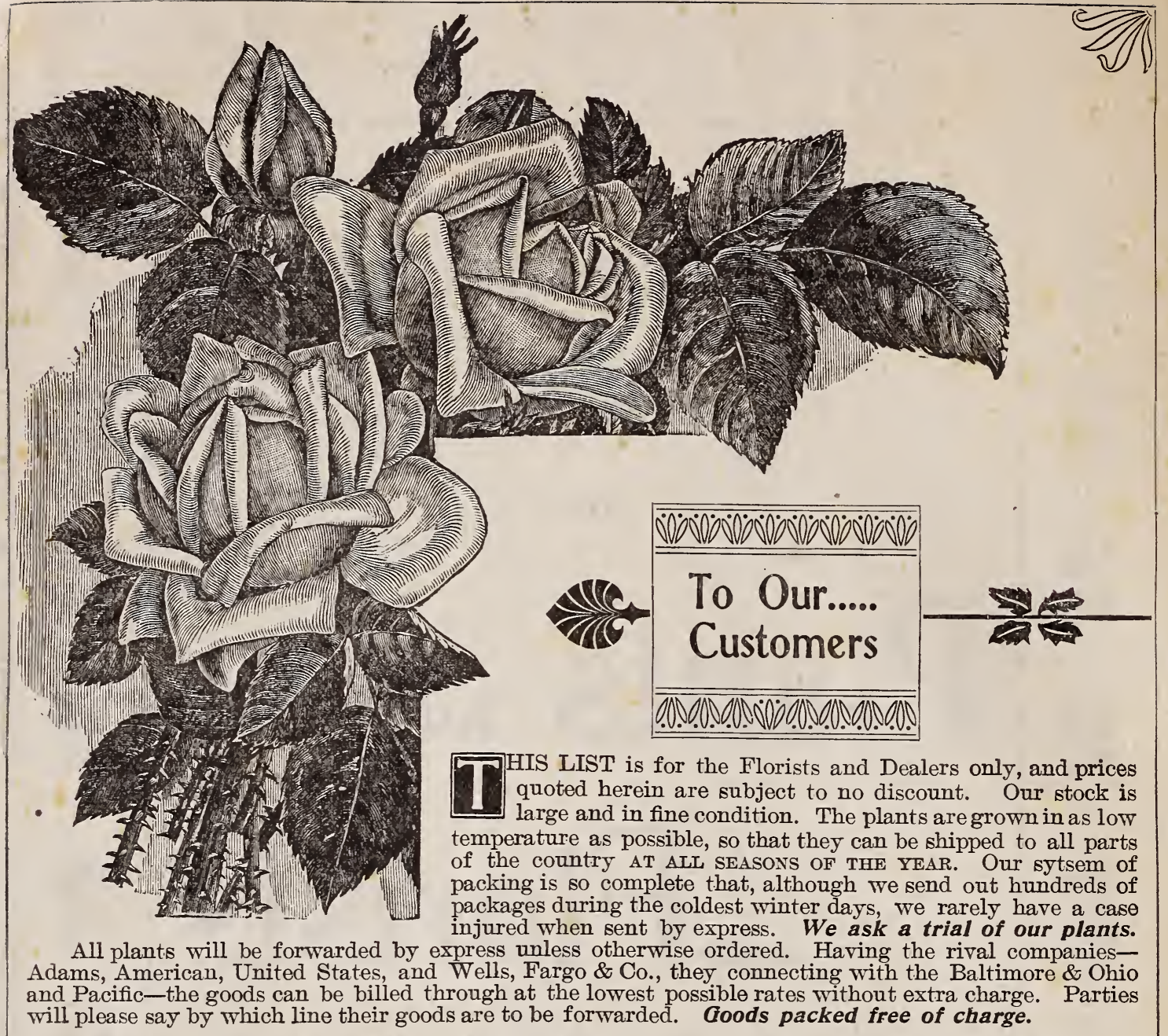

\section{CONDITION OF SALE OF PLANTS}

- - PLEASE READTHIS OEFORE - - -

We quote in this catalogue prices per single plant, per dozen plants and per hundred plants. If less than three plants of variety or kind (we do not mean a general class, such as roses, geraniums, etc., but a certain variety in such class) are ordered, the price per single plant must be allowed.

If three or more plants of a variety are ordered, the rate per dozen will apply. Not less than three plants of a variety will be sold at dozen rates, and single rates must be allowed at all times when one or two plants of a variety are taken. Kindly observe this in ordering.

\section{NO ORDER WILL BE FILLED FROM THIS LIST FOR LESS THAN $\$ 3.00$}

TERMS-Our terms are Strictly Cash. It will be readily seen that at our prices we cannot afford to take any risks. Special pains are taken to pack lightly, thereby reducing the expense of transportation to a minimum. Everything labeled.

RENIT TANCES-Should be made by Draft Postoffice Money Order, or Registered Letter. Remittances in any other way are entirely at sender's risk. Personal checks will not be accepted.

CASH ON DELIVERY-Plants to be sent C. O. D. must have one-fourth of the amount with the order. PLANTS BY MAIL-At the rates per single plant we will send by mail, postage paid. At per dozen and one hundred, one-fifth additional; but we would earnestly recommend, when it is possible, to have your plants sent by express.

NEW LOW EXPRESS RATE-We call your attention to the new low express rate, which is a reduction of 20 per cent. from the regular merchandise rate at which plants have been expressed heretofore, and also that packages of less than one hundred pounds are billed at one hundred pound rates.

ADDRESS MCGREGOR BROTHERS,

SPRINGFIELD, OHIO. 


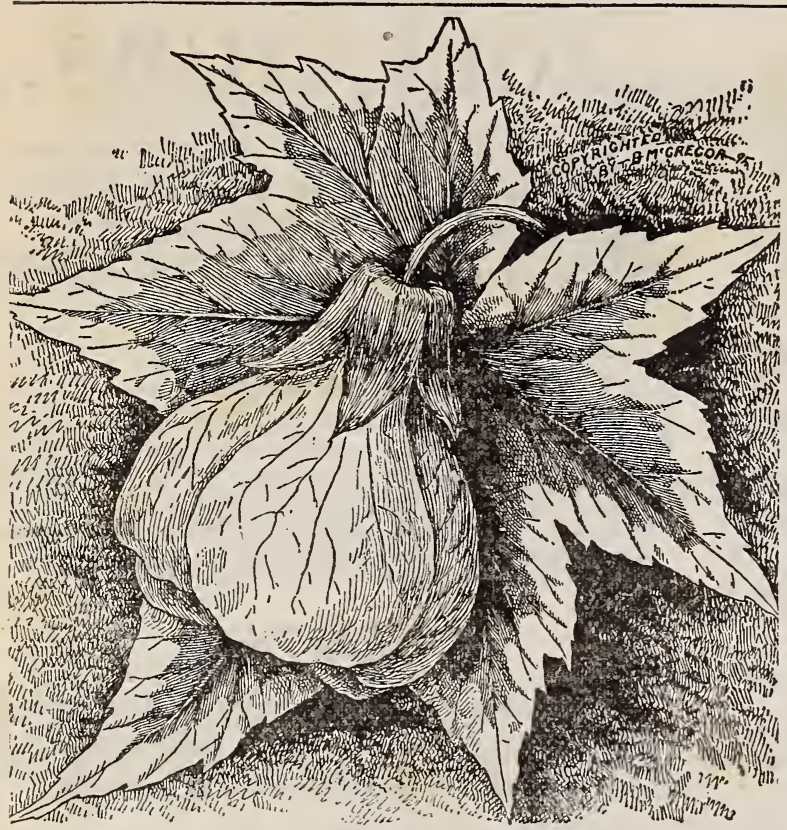

Souvenir de Bonn.

AMOMUM NELEGUEITA.

Belongs to the Ginger family; produces the Cardamon seeds of commerce. In growth it represents a miniature Canna; Makes a very pretty put plant. Foliage quite fragrant. Price, $50 \mathrm{c}$ per dozen; $\$ 4$ per 100 .

\section{ALOYSIA CITRIODORA-Lemon Verbena.}

Indispensible for the delightful fragrance of its leaves in the construction ot bouquets, etc. Price, $50 \mathrm{c}$ per dozen; $\$ 4$ per 100.

\section{ASPARAGUS SPRENGERI.}

When introduced, at a high price, a little over a year ago, this variety was received with some hesitation as to its desirability, but after only a limited trial it has come forward with such prominence that the supply will be inadequate to the demand for some time to come. Not only is it useful for cutting in sprays for fine cut-fiower work, more particularly in connection with large fine cut-lower work, more particularly in connection with large roses, etc., but grown in suspended pots it makes one of the pretas, for example, in the decorations of mantels, nothing can equal it. Fine $2 \frac{1}{2}$-inch pots, $75 \mathrm{c}$ per dozen; $\$ 5$ per 100 .

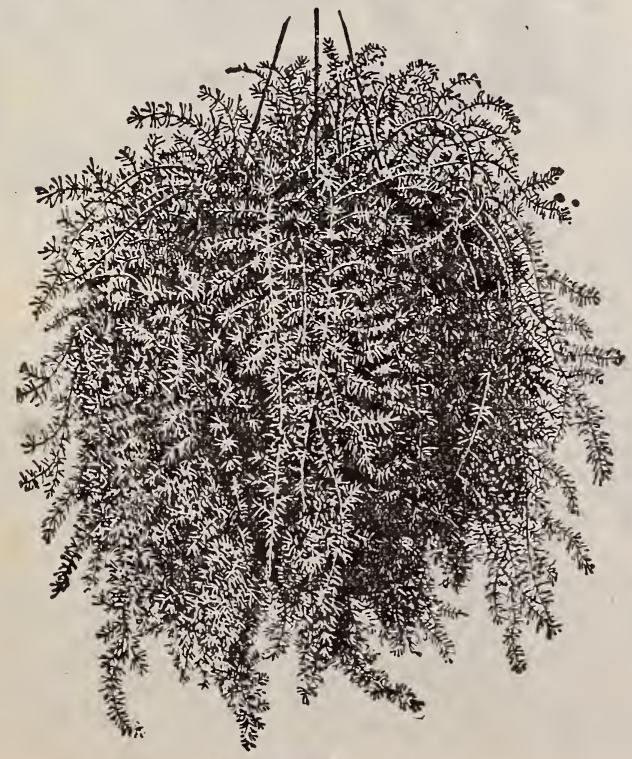

Asparagus Springeri,

\section{New Abutilon..} Souvenir de Bonn.

This is entirely different from anything we have had before in the way of variegated Abutilons. It is a strong upright grower, with large, bright-green foliage, dis tinctly edged with a bruad band of creamy-white and yel. low. Flowers very large, on stems eight to nine inches in length. Color bright orange-red, very effective with its beatifully variegated foliage. It is one of the most distinct and showy ornamental foliage plants that has come to our notice in years, and when better known it will be used in large quantities in connection with Palms, Drace nas, Rubbers, etc., for decoration purposes. Fine plants, $50 \mathrm{c}$ per dozen; $\$ 4$ per 100 .

\section{Abutilon, GOLDEN BELLS. \\ (Golden Fleece.)}

A bright golden-yellow Abutilon of strong, vigorous habit and very free flowering. There have been number of yellow Abutilons introduced during the past few years, but they all lack richness of color. The variety now offered combines large size, fine form andidepth of coloring, and will become the leading yellow variety. Price, $50 \mathrm{c}$ per dozen; $\$ 4$ per 100.

\section{ABUTILONS.}

General collection of the best market kinds. Price 10c each; 50c per dozen; $\$ 4$ per 100.

ANTHERICUM VITATUM-Folia Variegata.

A beautiful plant with recurved, graceful foliage, which attains a growth of about three feet. The leaves are dark-green, beautifully marked with broad strines and bands of creamy-white color. Price, 4 -inch pots, $75 \mathrm{c}$ per dozen.

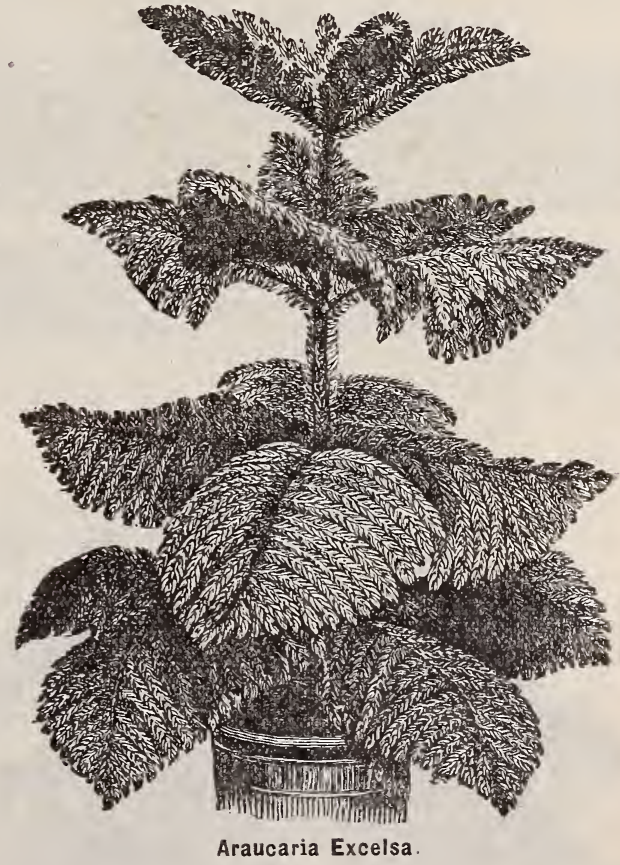

ARAUCARIA EXCELSA.

(Norfolk Island Pine.)

Various names have been selected for this grand plant to properly convey to the mind the appearance of it Some have called it the "Christmas Tree Palm" from its resemar "Stmblancefto a Christmas tree, others have called it the perfect star, but no descriptive a quate idea of its beauty. It has deep-green, feathery foliage, arranged in whorls, rising one above the other at reg ular distances; its symmetry of form, grace and beauty of foliage are unequalled in the vegetable kingdom. It is easily grown in the house and is highly ornamental. cut.) Fine plants, 5 -inch pots, 12 to 15 -inch, 3 and 4 tlers, price, $\$ 1$ each.

ALYSSUM.

Double White-Has large, double white flowers. Price, 40c per dozen: $\$ 3$ per 100 .

VARIEGATA-Variegated foliage, double flowers Price, $40 \mathrm{c}$ per dozen; $\$ 3$ per 100. 


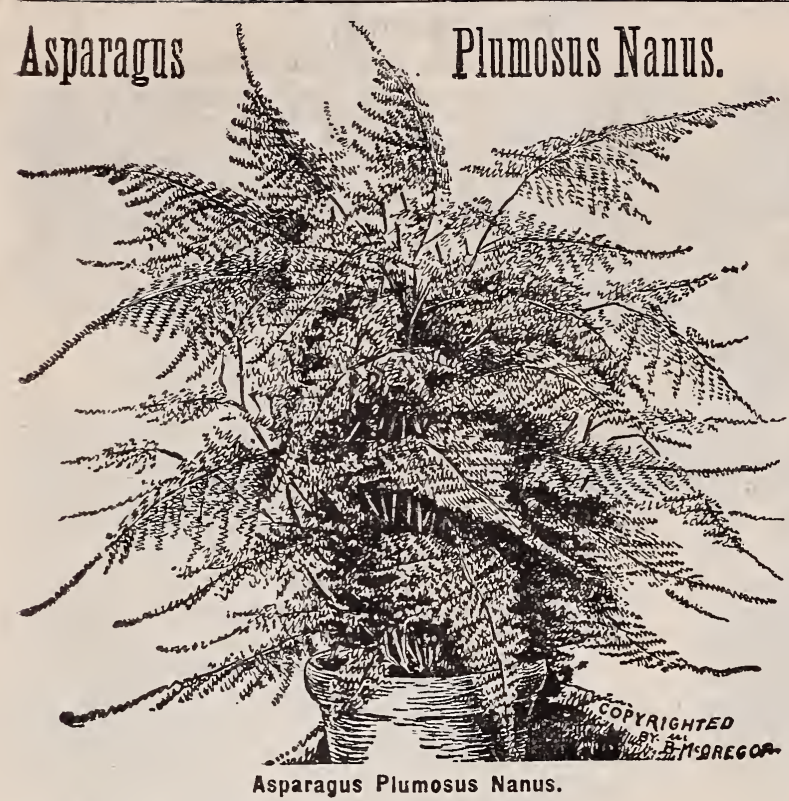

\section{..AGERATUMS..}

A good collection, containing the following sorts: Price, $40 \mathrm{c}$ per dozen; $\$ 3 \mathrm{p}$ er 100.

White Cap-New. It is, without doubt, the best white variety ever introduced.

Variegatum-Beautiful variegated leaves.

Tapis Blue-This is the best blue Ageratum for bed ding, etc., yet produced. Price, $40 \mathrm{c}$ perdozen; $\$ 3$ per 100

\section{Ageratum... \\ Princess Pauline.}

A most distinct and novel variety of dwarf, compact habit, rarely exceeding five inches in height, its peculiarity being that both colors, blue and white, are combined in the same flower; the body of the flower beirg white, while the stamens are of a light sky-blue, giving the flower a pretty variegated appearance. One of the most distinct new bedding plants that has come under our observation this season. Price, 5c each; 50c per dozen; \$3 per 100.

\section{ACHYRANTHUS.}

Indispensable for bedding purposes, either in massing or ribboning, their brilliant-tinted leaves forming a marked contrast with all other plants, being much hardier than Coleus. They are considered preferable for massing and ribbon lines. Price, $60 \mathrm{c}$ per dozen; $\$ 2.60$ per 100.
ASPARAGUS PLUMOSUS NANUS.

One of the handsomest of our foliage plants. The leares are a bright green, gracefully arched, and as finely woven as the finest silken mesh. Their lasting quality, when cut, is remarkable, retaining their freshness for weeks, hence it ranks as the most voluable plant we have for this purpose, survassing Maiden Hair Fern in grace, fineness of texture and richness of color. See illustration. Price. $60 \mathrm{c}$ per dozen; $\$ 5$ per 100 . Fine $31 / 2$-inch pots, $\$ 1$ per dozen; $\$ 8$ per 100 .

Asparagus Tenuissimus-We cannot too highly praise this beautiful plant. If so desired, it can be grown like a Smilax or on a trellis. Its fine filmy foliage is indispensable in bouquets, and will keep for several days after being cut, without wilting or changing color. Price, $60 \mathrm{c}$ per dozen; $\$ 5$ per 100.

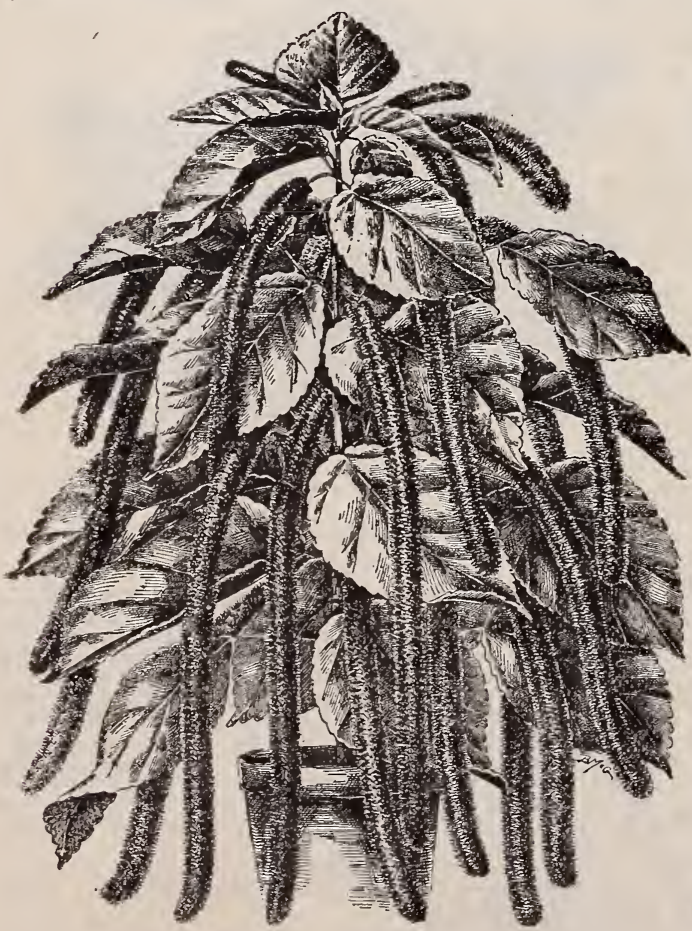

Acalypha Sanderii.

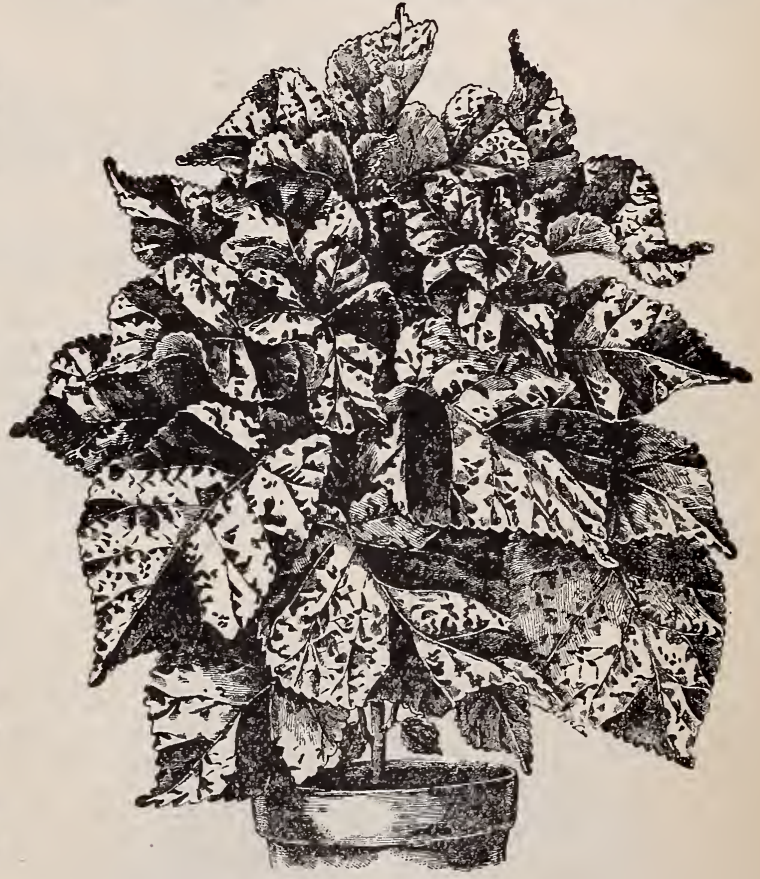

Acalypha Tricolor.

Acalypha Tricolor-A beautiful plant, with large highly-colored leaves. Bright red, with blotches of crimson-bronze. See cut. Price, 6c each; 60c per dozen; $\$ 4$ per 100 ,

Acalypha Marginata-Dark bronze, with rose-margined foliage This variety equals the showiest varieties of Coleus in effect, and has besides a decided advantage over any Coleus-namely, to be hardier and not liable to wilt in the hottest and driest weather. Price, 6c each; 60 c per dozen; $\$ 4$ per 100 .

Acalypha Sanderii-Known also as Philapene Medusa or Chenille Plant (Comet Plant.) A sensational novelt Silver medals have been awarded it at Boston and New York. Leaves are dark green, from the axil of which springs a long, drooping spike of glowing crimson-scarlet flowers, nearly an inch in diameter and from eighteen to twenty-four inches long, very velvety in texture, reminding one of a long piece of brilliant chenille. An exceedingly curious and interesting novelty; unlike any other decorative plant. This plant is never out of bloom. It is bound to have a large sale on account of its oddity and rarity. Price, $25 \mathrm{c}$ each; $\$ 2.50$ per dozen. 


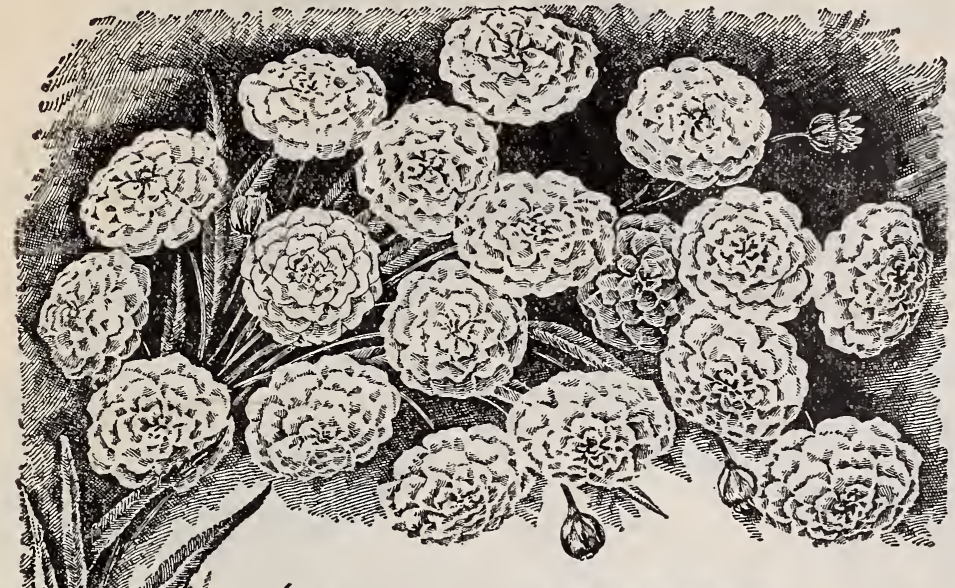

New Achillea, the Pearl.

NEW ACHILLEA THE PEARL.

We take much pleasure in callin specisl attention to this new plant, as it is one of the most beautiful and useful. It is a hardy perenial, the top dying down to the ground every winter. A plant will produce hundreds and even thousands of flowers the first summer, but when established the scennd year frequently have more than five hundred perfect flowers on the plant at the same time. It commences to bloom early in July, is a perfect mass of beautiful flowers till frost, the same bloom keeping perfect two or three months. Its flowers are pure white, perfectly double, and produced in large sprays, making it one of the finest cut flowers for bouquets, vases, baskets, etc. Price, $40 \mathrm{c}$ per dozen; $\$ 4$ per hundred.

BEOONIA ARGENTEA GUTTA TA.

This variety is an introduction of $M$. Lemodie, and is cross between Olbia and Alba Picta. This beautiful sort has the silvery blotches of Alba Picta and the grace and beauty of growth of Olbia. It has purple-bronze leaves, oblong in shape, with silver markings, and is in every way a most beantiful

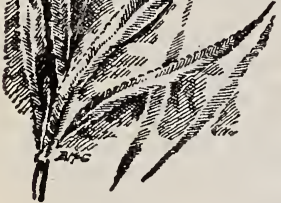
Begonia. It produces
dozen; $\$ 3$ per hundred.

BEGONIA THURSTONI.

This Begonis is cross between B. Metallica and B. Sanguinea, having the bright red oling leaves, and bright metalic green, shading to red, in the foliage and veining underneath the leaves, and bright metalic green, shooth glossy leaves and younger growth on top, with the deep veinings of the Metallica and smooth glossy leaves and become a beautiful shell pink- Price, 60 cents per dozen; $\$ 4$ per hundred.

BEGONIA VERNON.

This excellent variety is of unusual merit as a bedding gort; foliage rich glossy green, often shaded deep bronze, changing to a beautiful clear rose in the open flower. Price, 50 cents per dozen; $\$ 3$ per hundred.

\section{BEGONIA PRESIDENT CARNOT.}

A remarkably strong growing variety, of stiff, upright habit foliage larg and sownt in Rubra, but more than twice as large; upper side deep green, under gide purplish red, flowers beautiful coral-red, in large pendent panicles. Price, 60 cents per dozen; $\$ 4$ per hundred.

\section{CRIMSON-LEAVED BEGONIA, SANGUINEA.}

A showy variety, with very large leaves; upper side of which is a rich olive, under side crimson, and of a peculiar leather-like substance, dainty flowers, light rose to white. Price, 50 cents per dozen; $\$ 4$ per hundred.

\section{BEGONIA RUBRA.}

One of the finest Begonias in cultivation. Its dark, glossy green leaves, combined with its free flowering habit, make it one of the very best plants for house or conservatory decoration. The flowers are a scarlet rose color. Price, 60 cents per dozen; $\$ 4$ per hundred.

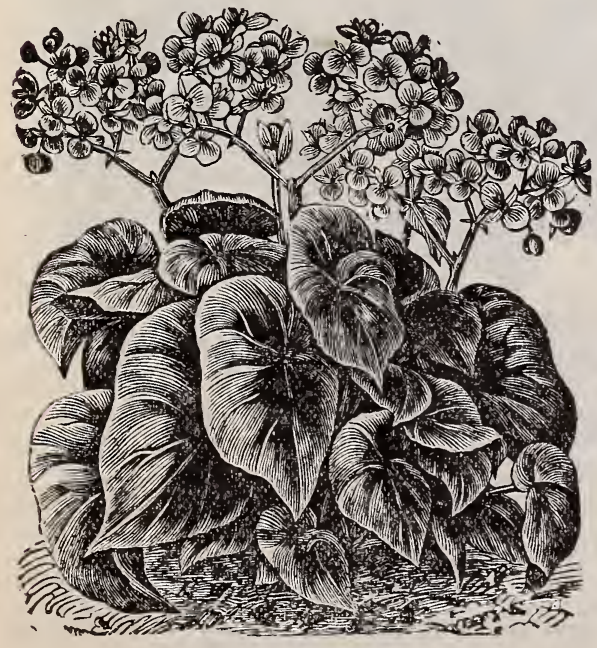

Begonia Sanguinea.

\section{BEGONIA M. DE LESSEPS.}

A charming variety on the order of Argentea Guttata, the leaf being four times the size seen in that variety, while the silky texture is the same, and it is beautifully spotted with silver. A very strong, free growing variety that will succeed with any ordinary care, growing rapidly anfl seeding out quantities of leaves. Price, $50 \mathrm{c}$ per dozen; $\$ 4$ per hundred.

\section{BEGONIA ERFORDIA.}

A sterling novelty for florists. Begonia Erfordia has all the good qualities of the famous bedders, Vernon and Dewdrop, and is a novelty we can strongly reconemend. It will stand the strong sun in summer, and is one mass of bloom from June until frost. It is also a very showy pot plant for spring sales. Habit of growth strong and compact; color deep rosy pink. We have a splendid stock and offer it an exceptionally low price. Price, $50 \mathrm{c}$ per dozen; $\$ 3$ per hundred. a

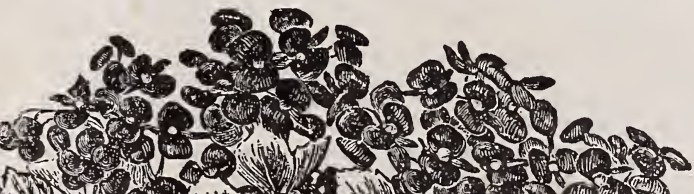




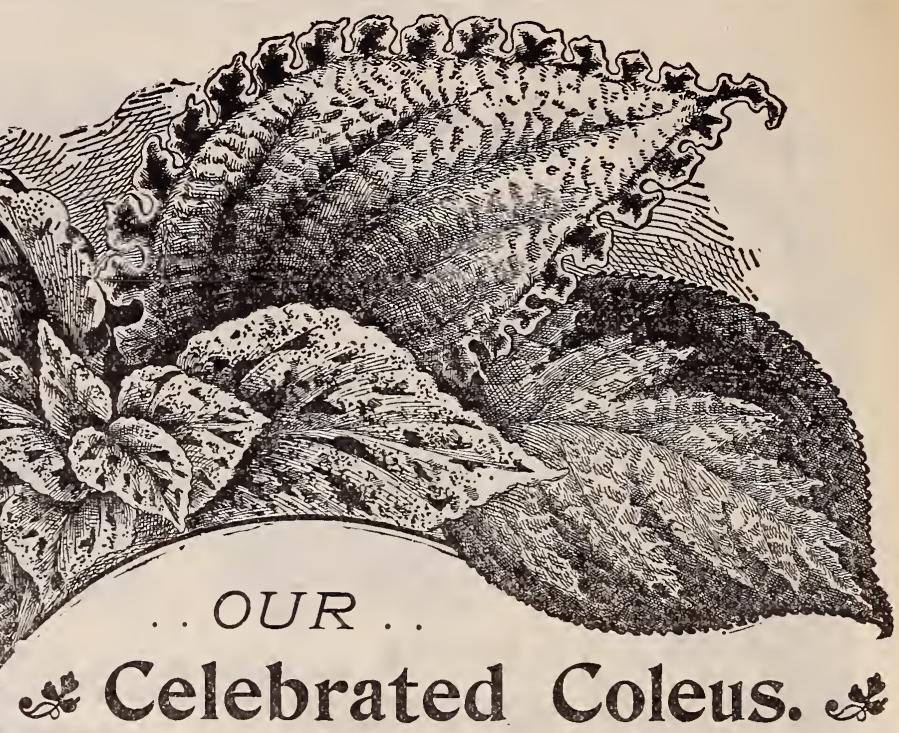

STANDARD MARKET SORTS-A fine stock of the best and most distinct named kinds. Price, 40 cents per dozen; $\$ 2$ per hundred.

MIXED VARIETIES - Not named, in endless variety. Price, $\$ 1.50$ per hundred.

CYCLAMEN, Or PERSIAN VIOLET.

There is no more ornamental plant for the greenhous $\theta$ or parlor culture than the Cyclamen. It grows readily, blooms freely and remains a long time in flower. Keep them in a cool, light place, watering lightly until growth begins; then water freely and give plenty of light and air. On the approach of cool weather remove to a warmer situation, the parlor or greenhouse, but keep them near the light. The whole secret perature. Nice bulbs, 50 cents per dozen; $\$ 4$ per hundred.

CEREUS ORANDIFLORA $=$ Night Blooming Cereus.

The most beantiful flower in the world. Its flowers are very large, of pure satiny-white, with outside petals faintly tinged with redish-brown. It is also deliciously fragrant. Price, 6 cents each; 50 cents per dozen; $\$ 4$ per hundred.

\section{CESTRUM PARQUI.}

This well-known and highly prized plant, blooming nearly all the year round, is a native of Chili; an excellent garden plant, grcwing rapidly ; foliage long and of deep green color, producing its richly fragrant flowers at every joint; sweet producing its rit is also adapted to house culture. Price, 50 cents per dozen; \$4 per hundred.

\section{CESTRUM AURANTICUM.}

Pure orange, winter blooming variety of night Jasmine. Price, 50 cents per dozen; $\$ 4$ per hundred.

\section{FLOWERY BEGONAS.}

Price, 50 Cents Per_Dozen; \$3 Per Hundred.

Fuchsoides Coccinea-Beautiful pot plants. Graceful branches and pendulous clusters of coral-red flowers. Very floriferous.

Foliosa-A beautiful small-leaved variety. Indeed, the millesteaf of all Begonias. Bright pink flowers in profusion.

Carrieri-Always producing a profusion of beautiful pure white bloom in clusters

Marguerite-Leaves bronzy-green, somewhat resembling Metallica ; large trusses of light rose'colored flowers.

Nitida Alba-A strong growing, profuse blooming variety, producing immense panicles of pure white flowers.

Rosea-The exact counterpart of the well-known Begonia Rubra, only it has bright rose colored flowers.

Weltoniensis Alba-Lovely white flowers and very abundant.

\section{COLEUS, ROOTED CUTTINGS.}

plants, put up in
cents per hundred A not less than ten of one variety. Price, 75 cents per hundred;
$\$ 3$ for five hundred, $\$ 5.50$ per thousand. Coleus Vershaffelti and Fowers tubular in shape, one and a half to two inches long, and have

\section{NEW CUPHEA TRICOLOR.}

wo bright scarlet wings at the end of each flower; the tip of the flower is
right purple, the stamens are pure white. The plants are always in bloom when given proper care. It grows into a bushy plant about fifteen inches gh, and makes an elegant appearance fo rbaket or bedding. Price, 5 cents ach; 40 cents per tozen; $\$ 3$ per hundred.

\section{LITTLE GEM, FEVERFEW.}

This is a grand improvement on the old dwarf Feverfew. It is very dwarf, attaining a height of old eight or ten inches. The flowers are large, of a more perfect form, and of the purest white. Price, 40 cents a dozen; $\$ 2.60$ per hundred.

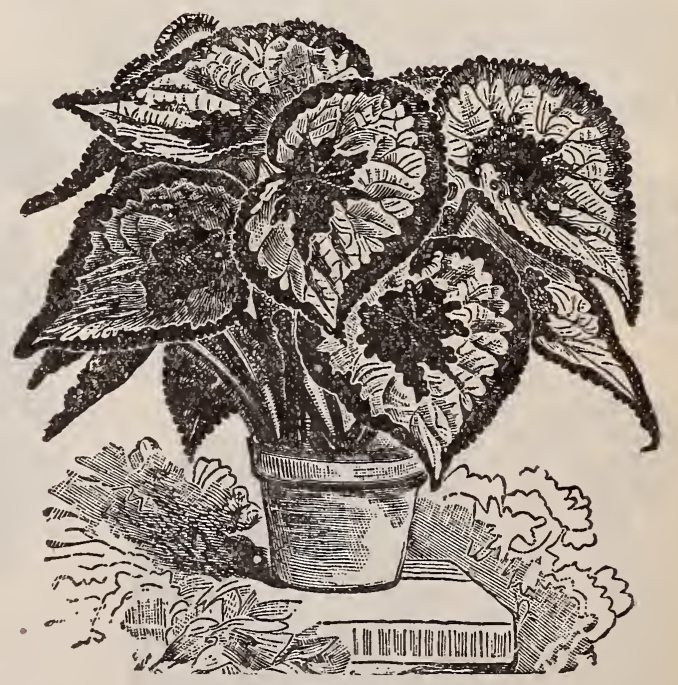

Begonia Rex.

BEGONIA REX.

Fine plants and a choice assortment. In best ramed varieties. Price, 75 cents per dozen; $\$ 5$ per hundred. 


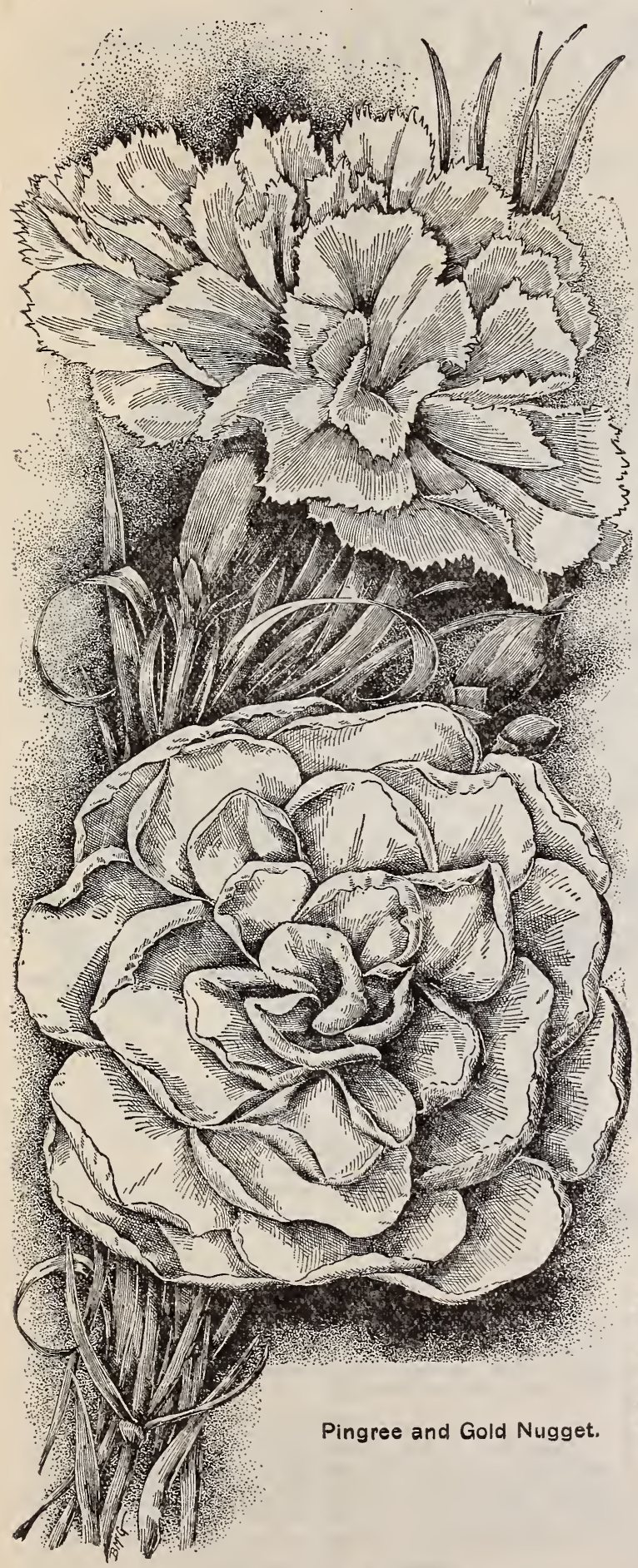

\section{newer. Carmations.}

Nice Plants Ready Now Jan. Ist, 1900.

\section{MAYOR PINGREE.}

Color clear lemon yellow, lightly marked with pink and occasionally splashed with white. A very strong, robust grower, continuous bloomer, and not a cropper. Blooms measure two and a half to three inches and over in diameter. Stems extraordinarily stiff and from 18 to 30 inches long as the season advances. Excellent keeper, very productive. Good plants ready now. Price, 50c per dozen; \$4 per 100. Rooted cuttings, \$2 per 100 .

\section{GOLD NUGGET.}

Clear, deep yellow, slightly marked with red. The flrst real rival of Buttercup in color. In point of productiveness and constant blooming, far aflead of Buttercup. Strong grower, free, early and continual Bloomer. Medium-sized, high-centered flower, does not burst. Stem long and stiff, and bloom a first-class keeper. The best yellow we have ever grown, and a prize-winner wherever shown. Reports from many growers confirm our opinion that it is the most profitable yellow Carnation to date. Nice plants ready now. Price, $60 \mathrm{c}$ per dozen; $\$ 5$ per 100 . Rooted cuttings, $\$ 2.60$ per 100 .

\section{EVELINA.}

A fine commercial white. Its strong points are its earliness, great freedom and continuity of boom. It has slender stems, always stiff; is a pure white of large size and fine form. It has so many good qualities, united to its freedom, that we feel sure that it will rank very high with the grow. ers. One of the largest growers in the country is using it as his only white. Plants ready now. Price, $60 \mathrm{c}$ per dozen; \$3 per 100 , Rooted cuttings, $\$ 1.50$ per 100 .

\section{TRIUMPH.}

A pure, rich pink, a little darker than Scott; flowers often measure three and a half inches across; early and very free; strong, robust grower; very long, stiff stems; never takes rust. The finest commercial bright pink to date. Price, plants $50 \mathrm{c}$ per dozen; $\$ 4$ per 100 . Rooted cuttings, $\$ 2$ per 100.

\section{...BON TON...}

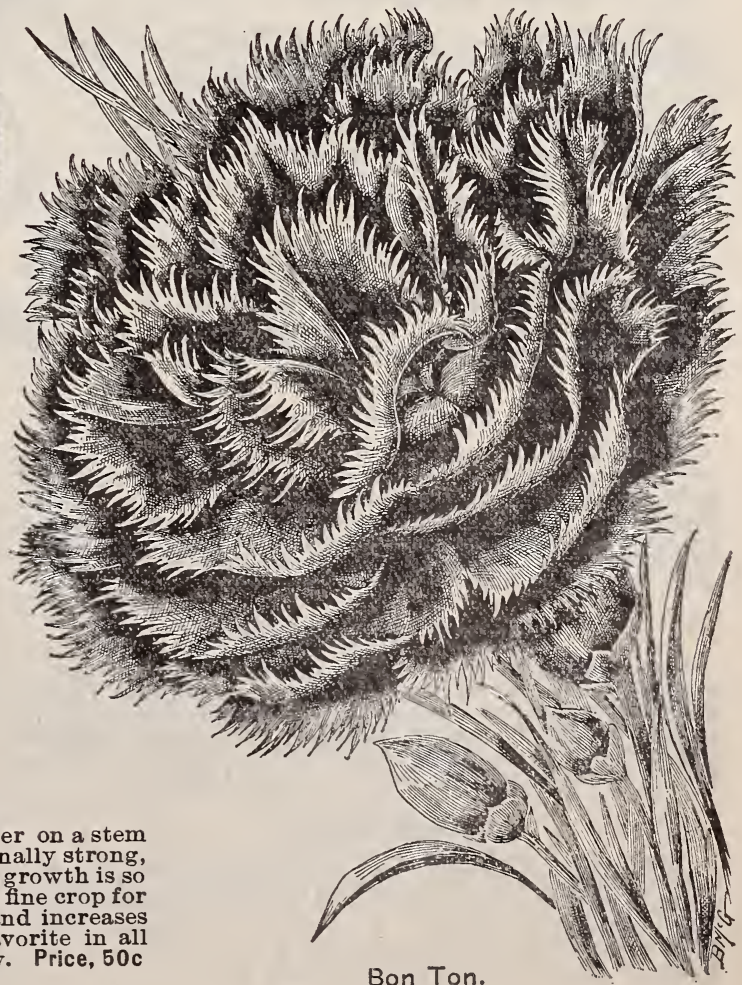

Bright, warm scarlet, large, deeply fringed, fragrant fow as stiff as a reed. Perfect calyx. Habit of the plant exceptionally strong, resembling Portia, but much heavier and more vigorous. The growth is so strong that it does not need staking. Comes into bloom with a fine crop for Christmas when scarlet Carnations are so much in demand, and increases in quantity and quality as the season advances. A great favorite in al per dozen; $\$ 4$ per 100 . Rooted cuttings, $\$ 2$ per 100 . 


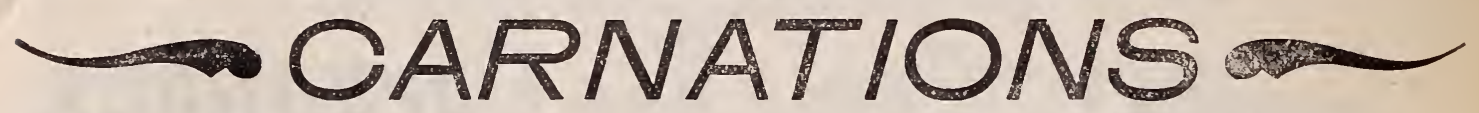

\section{MRS. GEO.}

\section{BRADT.}

Color clear white, heavily edged and striped with bright scarlet, giving it a very bright and cheerful appearance. Flowers enormous and full, with center petals standing erect, giving the bloom a well-rounded form. Habit strong and vigorous, but dwarf enough for side benches. A constant bloomer from early to late, and is probably the most striking carna. tion of recent introduction. A grand commer cial carnation. Its biooms sell at the highest prices in all markets. No variegated carnation Fet introduced can equal the enormous striking blooms produced by this variety. Unquestionably.the best of all variegated carnations. Price, plants, 75 cents per dozeñ; $\$ 6$ per huridred: rooted cutitings, $\$ 4$ per hundred.

\section{JUBILEE.}

Color intense scarlet; very large flower, on long, slender, but stiff stems; strong, non. bursting calyx. This variety is doing well with a number of growers. Seems to do best when grown inside all summer, as then it is not so much affected with rust as when lifted, and also does best on a strong, stiff soil Price plants, 50 cents per dozen; $\$ 3$ per hundred; rooted cuttings, $\$ 1.50$ per hundred.

\section{DAYBREAK.}

Delicate sal mon-pink; vigorous grower Color, when at its best, very soft, clear and pleasing. Flower will not stand in full sun as the color bleaches and should be shaded when sun is strong. A very popular variety, which seems to give a paying crop in nearly all localities. Does well on nearly all noils Should be grown cool to give best results. Price, plants. 50 cents per dozen; $\$ 3$ per hundred; rooted cuttings, $\$ 1.50$ per hundred.

\section{WM. SCOTT.}

Bright pink; one of the most productive large flowered pink Carnations; flower medium to large size, two to three inches, on long stems, of good substance anl stiffness. More generally grown than any other carnation. Price. plants, 50 cents per dozen; $\$ 3$ per hundred; rooted cuttings, $\$ 1.50$ per hupdred.

\section{FIREFLY.}

Deep scarlet, resembling Garfield; early: continuous bloomer; large, well-formed flower $2 \frac{1}{2}$ inches and more in diameter; strong, vigorous foliage covered with heavy bloom. Introducer claime it to be disease proof. Price, plants $50 \mathrm{c}$ per dozen, $\$ 3$ per 100; rooted cuttings, $\$ 1.50$ per 100.

\section{FLORA HILL.}

Very free in growth and in coming into bloom. Strong calyz moderately stiff $s t \in m$, very large flower. Under ordinary culture brings good flowers throughout the season. Stem rather weak with first crop, but stiffens up as season advances. Is doing first-rate in stiff soils, which seems to indicate that it needs a heavy soil. Price, plants $50 \mathrm{c}$ per doz, $\$ 3$ per 100; rooted cuttings, $\$ 1.50$ per 100 .

\section{LIZZIE MCGOWAN.}

Color white. Medium to large flower, on thin wiry stems, frequently not stiff enough to properly support the flower. Very productive and generally grown. Under extra culture on suitable soils this variety produces 3 -inch blooms on 16-inch stems, which, however, are hardly stiff enough. Price, plants 50c per dozen, \$3 per 100; rooted cuttings, \$1 per 100 .

\section{ARGYLE.}

Color, a lovely shade of carmine pink, or rather pure cerese; flowers $2 \frac{1}{2}$ to 3 inches in diameter, borne on stems 18 inches long: healthy, and free from rust; perfect calyx early, continuous bloomer. The flower is of ezquisite form; promises to prove a leader among pinkr. Price, plants $50 \mathrm{c} \mathrm{per}$ dezen, \$4 per 100; rooted cuitirgs, \$2 per 100.
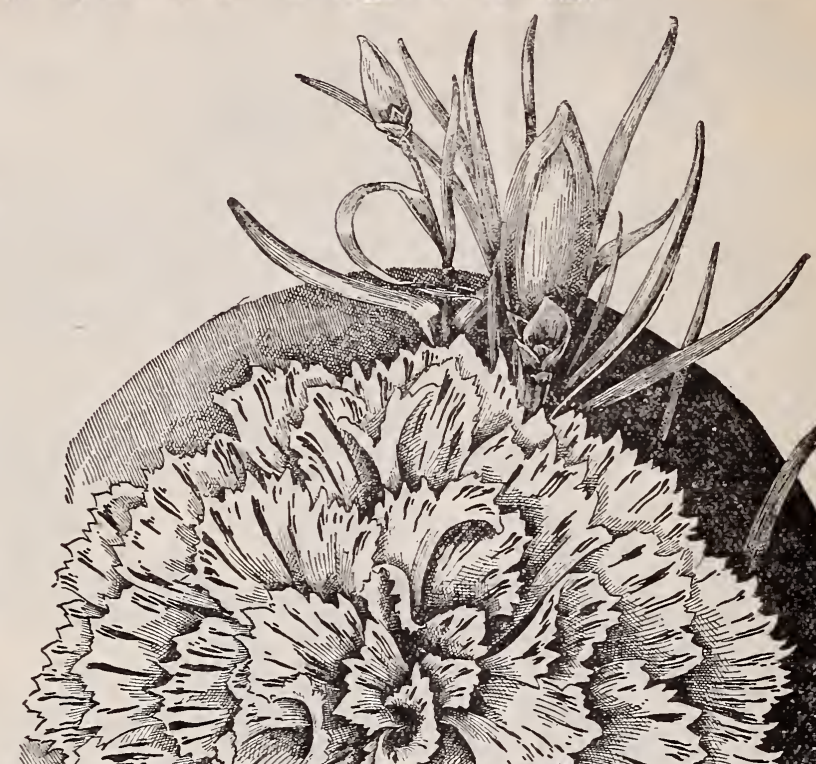


\section{THE BEST CHRYSANTHEMUMS.}

READY FEBRUARY

Ist.

\section{Che best varieties for pot growing or bench planting for cut flowers. Price, $\$ 3$ per bundred. (J)here the Selection is more or less left with us we will furnish) 200 finely assorted kinds for $\$ \mathbf{5}$.}

Joseph H. White-Very large white variety, with upright petals, forming a nicely rounded flower of great substance.

J. A. Lager-Reflezed, of great depth. Petals long and twisted, open at the end, of beautiful pure yellow.

Kioto-Incurved Japanese variety. The color is deep yellow, with a peculiar waxy luster; petals incurved and twisted. L. Canning-A most exquisite white, absolutely pure. The flower is quite regular in form, very large and flat.

Lillian B. Bird-This beautiful and unique variety is of an exquisite shrimp pink in color.

Niveus-A grand, snow white variety: center irregularly incurving with outer petals reflexing nearly to the stem. Constitution robust; foliage large and abundant, while the keeping qualities of the flowers are unsurpassed.

Mrs. I. C. Price-A lovely yellow, bright as gold; blooms very large; petals long and slender, arranged in a whorl.

Mrs. J. G. Whildin-A handsome yellow variety of light tint, fine, large size and splendid form. A magnificent addition to the scarce, very early, large flowering varieties.

Miss Mary Weightman-A magnificent and very distinct chrome yellow; in form loose and feathery, but very large and full.

Mme. F. Bergmann-The finest of all the early whites; very large and full, and of the purest white, with creamy center a strong, sturdy habit; fine foliage. The most popular white variety with florists for early forcing.

Marion Henderson-Bright, clear, light yellow; full double petals, long, narrow and twisted. One of the best double yellows.

Miss Gladys Spaulding-One of the best whites extant; a grand spherical Chinese variety.

Mrs, E. G. Hill-One of the earliest of all large flowering sorts. Flowers very large; color delicate pearl pink.

Master of Ostrich Plumes-This beautiful new variety is of deep maroon, shaded and marked in scarlet; a decided advance in color and form that add much to this strange type of flower.

Cullingfordil - Reflexed; exceedingly brilliant crimson, richly shaded with scarlet.

Eugene Dailledouze-The grandest of all midseason yellows. Effiie Dean-(New.) Beautiful ivory white sport from Maud Dean, and of same form and habit.

Gloriosum-Light lemon color, with immense flowers; early.

Glory of the Pacific-This flne variety will rank among pink sorts as Bergmann does among the whites. It is of magnificent size and depth, with broad petals, which finally reflex, showing the clear pink color to excellent advantage.

Helen Bloodgood-Purest rosy-pink imaginable, without any trace of purple or magenta.

Ivory-Unexcelled for pot culture or cutting; pure white fiower of exquisite form and finish.

Louis Boehmer-(Pink Ostrich Plume.) The "Louis Boehmer" has the same wonderful hair-like growth or excrescence that appeared for the first time in the white variety, "Mrs. Alpheus Hardy.'

Maude Dean-An immense pink variety; finely incurved; petals broad, shell-shaped. One of the largest flowers exibited in the fall shows.

Miss Kate Brown-Early October flowering; flowers extra large; reflexed, with petals slightly twisted; color pure snowy-white.

Mrs. Perrin-Mrs. Perrin is the nearest approach to the true pink so long desired. It has slender, stiff stems; a short neck: ornamental foliage. The flower is of globular form, incarved, full and with a finish as soft as satin.

Mrs. M. M. Johnson - Extra early, deep golden yellow, singe incurved, dwarf; foliage fine and close up to the flower Mrs. Henry Robinson-In the entire Chrysanthemum fam. ily there is no grander white variety.

Mutual Friend-Very large incurved, the outer petals drooping, forming almost a perfect flower of the pures white.

Major Bonnaffon-Soft, clear yellow; full in the center eight inches in diameter and nearly as deep. In perfect form and finish: habit dark.

Mrs. M. R. Parker, Jr. - Very large, with broad cupping and incurving petals; the inner surfaces a deep, rich pink, the reverse a light, silvery shade.

Perle of Lyonaise-Bright clear golden-yellow, somewhat plumed, quite full; one of the very finest; of medium size; beautiful globular form.

Puritan-This is undoubtedly one of the choicest, as well as largest Chrysanthemums; a beautiful silvery-white, turning to pure white.

President Harrison-An immense cupped flower; outside petals salmon-red; center deep Indian red.

The Queen-One of the grandest of all whites, especially for exhibition.

Violet Rose-A grand variety; exceedingly free, of perfect form. A beauty combination of violet and rose in color.

W. H. Lincoln-A magnificent and immense full double flower, with slightly incurved petals. The color is pure golden-Jellow.

W. A. Manda-The flowers are very large, of a clear goldenyellow-the hairy growth being much more fully developed than in the other varieties of this type.

Yellow Queen-Very large incurving yellow, with broad petals: very highly esteemed by those who have learned its requirements and can bring it in early.

Good Gracious-Delicate peach pink; solid round form, petals incurved, irregularly overlapping each other; remark able for size, form and color.

Yellow Good Gracious-In form, size and habit same as above, uut color of a bright golden-yellow.

Ceo. W. Childs-The most nopular of all crimson red varieties. Very suitablo for specimen hot plants.

Mrs. Jerome Jones-Color delicate creamy white, some times tinged with light pirk; petals very broad, gracefully incurved. Very lasting aftef being cut.

Westerr: King-This, we believe, is the best white intro duced for commercial or exhibition blooms, or for plants, either bush or single stem. An incurved flower with outer petals slightly refiexing; pure white.

Marie-Early, full, double flowers of largest size; petals broad and spreading; color white, with delicate lemon center.

Inter 0 cean-A beantiful recurved flower; color glisten. ing, pearly white, with light suffusion of pink. A grand variety for any use.

Fisher,s Torch-Bright fiery red, the richest shade in Chry santhemums; large, fine flower.

Golden Trophy-A grand early dwarf grower, requires no tying; foliage very beautiful, and quite up to the flower very large for October; compact, crowded with petals, in curving into a complete golden ball.

Frank Thompson-A splendid flower, very nearly spherica] in form; petals ver broad and heavy, and finely incurving. It is very nearly white in color, only showing a touch of pearl-pink at the base of the petals.

v. H. Hallock-A rosy-pearl, of a marked waxy texture. The rosy color deepens toward the center.

Mrs. John Westcott-Creamy-pink, shading to white; flowers reflexed, of enormous size, produced on long stems, with luxuriant foliage. 


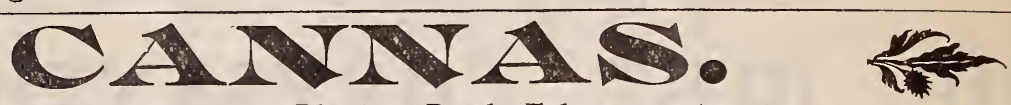

* * From Pots, Strong Plants. Ready February Ist. * *

Prices Unless Otherwise Noted, 50 Cents Per Dozen; \$4.00 Per Hundred.

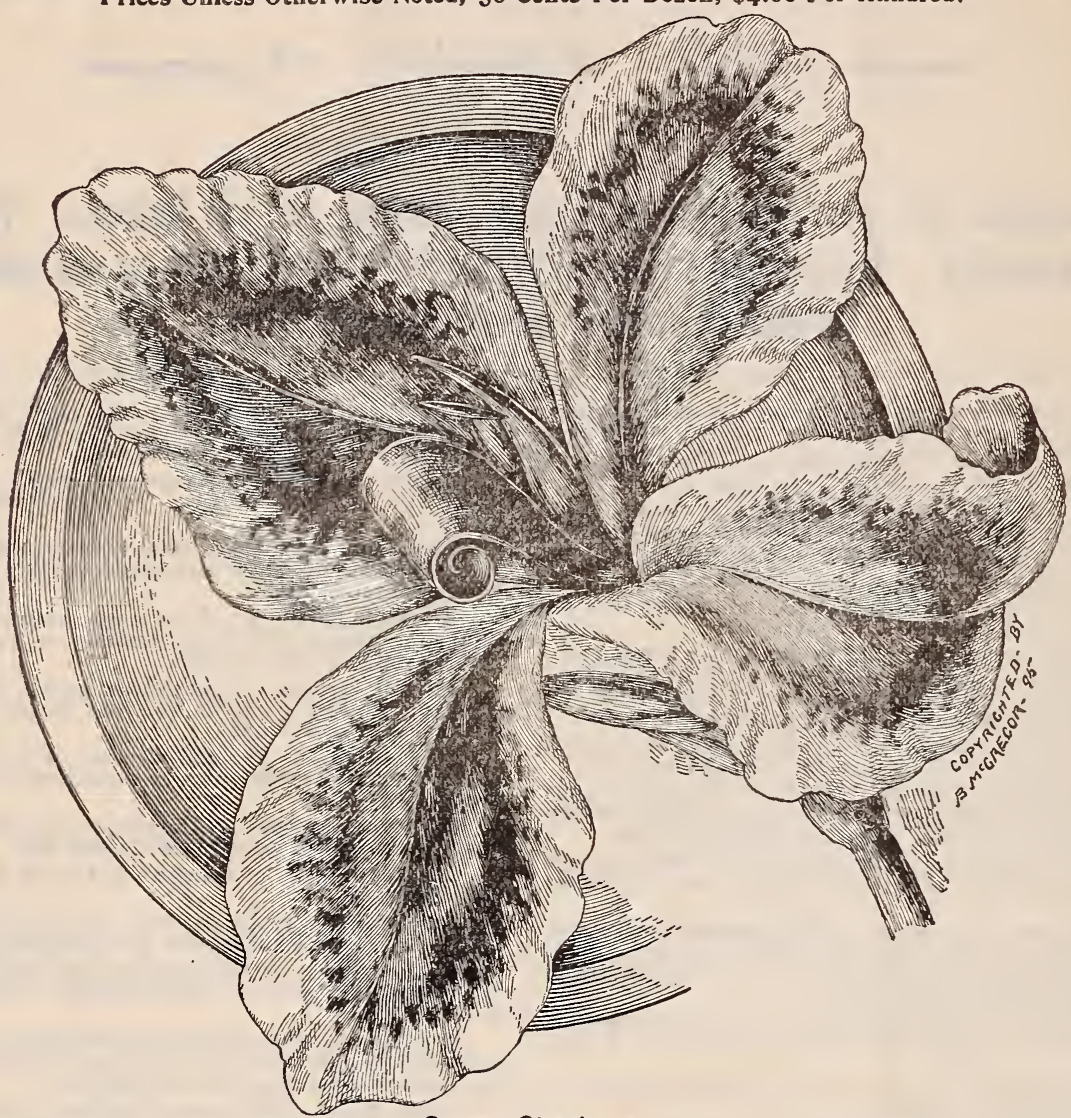

Queen Charlotte.

Austria-The flowers of this wonderful Canna when fully outstretched measure over six inches across, with strong stems each stem surmounted by tall spikes of golden yellow flowers standing upright like immense lilies.

Queen Charlotte-Our illustration clearly shows the shape and markings of the flowers, which are very large, with broad, rounded petals, slightly recurved; they are borne in immense heads, well above the foliage, and are most striking in color. A bright orange scarlet, deeply edged with bright canary yellow.

Emile Leclere-A strong grower; height, about three feet: foliage green, numerous flower stalks; of medium height: flower golden yellow, mottled and spotted crimson and scarlet;

Miss Sarah Hill-Very dwarf, handsome light green foliage, numerous, strong, compact flower stalks; flowers large, petals well rounded; superb amaranth carmine.

Duchesse De Mortemarte-A vigorous grower, with large leaves, throwing up numerous flower stalks; flowers large and round, composed of large, round petals; color yellow, very bright, lightly dotted carmine.

Paul Marquard-The individual flowers are large, and the flower spike very large, each flower standing out separately. The flower is as fine as the finest orchid. It might be described as a bright salmon, with a carmine tint.

Souv. De Asa Gray-Plant very vigorous; foliage green and produced in profusion. Flowers very large; beautiful citronyellow, striped with flame.

President McKinley-Pronounced by all the best dwarf crimson bedder introduced. Color a fiery deep crimson-scarlet, the nearest approach to the color of Alphonse Bouvier of any canna we have. It is an early, constant and immensely prof use bloomer. Price, 75 cents per dozen: $\$ 6$ per hundred.

Mile. Berat-Rosy pink, clear, distinct; the best of the pink cannas; good habit, strong Poliage. A decided novelty. Price, 60 cents per dozen; $\$ 5$ per hundred.

Chas. Henderson-Height, $21 / 2$ to 3 feet; color, brilliant deep crimson; broad deep green foliage, narrowly margined with bronze; standard crimson bedder.

Secretary Chabanne-Clear orange-scarlet; immense heads of bloom ; dwarf bushy habit; immensely productive of bloom the season through. One of the best of this class. Price, 60 cents per dozen; $\$ 5$ per hundred.
Gloriosa-A splendid dwarf variety of the Queen Charlotte type; vigorous, healthy habit; 18 inches to 2 feet in height; foliage broad, of a bright rich green. The flowers are borne in massive trusses, measuring 9 inches or more in length, and 6 to 8 inches in diameter. Price, $60 \mathrm{c}$ per doz., $\$ 5$ per hundred.

Madame Crozy-The color is a brilliant vermilion-scarlet, bordered with deep golden-yellow; the flowers are borne in great clusters, and in such profusion that they crown the plant with a blaze of glowing color.

President Carnot-Brilliant cherry-red flowers; splendid habit, deep purplish bronze foliage; a striking variety; very fine bloomer ; fine grower, its brilliant deeply colored flowers contrasting richly with the dark foliage. Price, 75 cents per dozen; $\$ 6$ per hundred.

J. D. Cabos-Color of flower light orange; good sized truss, borne fairly well above the foliage; one of the freest bloomers that we have among bronze cannas. Foliage deep bronzepurple; an exceptionally valuable sort and a distinct variety. Price, 60 cents per dozen; $\$ 5$ per hundred.

Florence Vaughan-Conceded by all to be the finest yellow spotted Canna. Flowers very large, of the most perfect form, with broad over-lapping petals, nicely rounded at the ends; color brilliant yellow, spotted with bright red; a strong, robust grower, and flowers very freely. Price, 60 cents per dozen; $\$ 5$ per hundred.

Pierson's Premier-A distinct improvement on Queen Char. lotte, being much dwarfer, much more brilliant in color, and withal a splendid bloomer. a grand pot plant and very desirable. Price, 60 cents per dozen; $\$ 5$ per hundred.

Statutaire Fulconis-As fine a variety in its color of soft, bright, cardinal red, as is Madame Crozy among the orange scarlets; the truss is enormous, composed of quantities of flowers; spikes freely produced; a magnificent grower; produces a mass of brilliant red.

Papa Canna-Color pure red; broad, light green foliage margined with distinct tracing $r^{\circ} \quad \mathrm{ze}$; immense truss with very large individual florf" 'spikes being pro duced on the same stem: Price, 60 cents per dozen; $\$ 5$ 


\section{FUCHSIAS.}

\section{SIIANDARDD \\ IXINDS.}

Price, except noted, 40 Cents per Dozen; $\$ 2.50$ per Hundred. Ready February loth.

Avalanche-Beautiful golden foliage, with a dark, double violet-purple corolla.

Charles Blanc-Single; sepals dark red; corolla rosy-amaranth; very free bloomer.

Crepuscule-A superb double; color of tube and sepals dark red, corolla violet, striped with rose.

DeMirble-Bright red reflexed sepals ; quite large corolla of rose and violet.

Depute Berlet-Corolla large and very double; violet, tube and sepals bi ight red.

Earl of Beaconsfield-Vigorous grow: ing, free flowering variety; tube and sepals light rosy carmine, corolla deep carmine.

EIm City-Sepals rich crimson; corolla deep purple; double; very free flowering; extra fine.

Flocon de Neige-Single; tube and sepals soft coral scarlet; the corolla is large, open and bell shaped; of the purest white.

Jupiter-This is a grand mammoth flowered Fuchsia. The plant is a strong upright grower : makes a handsome specimen in a very short time.

Lady in White-Double; one of the finest among the double whites; of good habit and free blooming.

Lovely-Another fine market variety. Tube and sepals white; corolla slngle; brilliant crimson; tinted magenta.

Mme. Van der Strass-Fine, large and elegant form ; sepals long and reflexed; pure red, corolla large; double white; the finest market double white Fuchsia.

Monstrosa Superba-Very large, double flowers; pure white corolla, beautifully reflexed; bright scar. let sepals.

Rose of Castile-Blush white sepals; rosy-purple corolla; one of the best of its color.

Purple Prince-Fine double variety; sepals scarlet; corolla a beautiful distinct blue; very dwarf.

Speciosa-Pale red tube and sepals; dark red corolla, there frequently being from 30 to 40 flowers on a single branch.

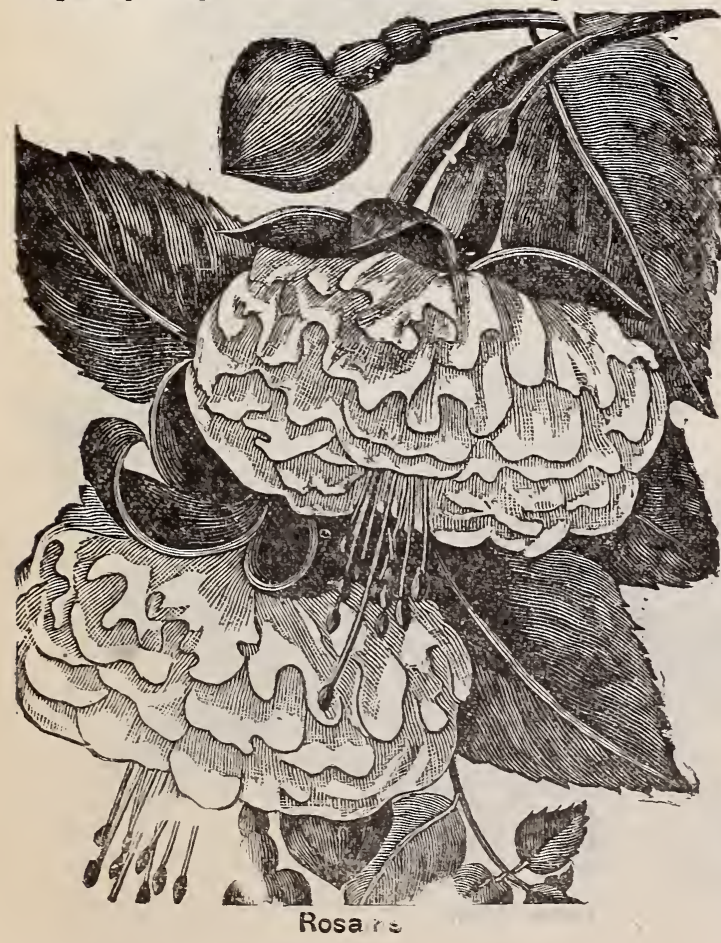
ed color; open flower; dark purple and very beautiful. One of the very finest of the Fuchsias.

Walter Long-Single; bright coral red tube and sepals; clear violet corolla, deeper in color toward edges.

Wave of Life-Foliage bright yellow; corolla bright violet; sepals scarlet.

\section{FUSCHIA PHENOMENAL.}

The largest Fuchsia we have yet seen-larger than Cham, pion of the World. The tube and sepals are brlght coral red: beautifully formed. The corolla, nearly $21 / 2$ inches across, is of the very richest violet shade. The habit is remarkably free, and it blooms more freely than any large variety we have seen. Price, 50 cents per dozen; $\$ 3$ per hundred.

Mme. Carnot-A remarkabfy free flowering variety, with flowers of very large size. The plant is of compact, symmet. rical growth, making fine shapely plants in quite small pots: tube and sepals deep coral red; corolls white, veined and suffused carmine. Price, 50 cents per dozen; $\$ 4$ per hundred.

Rosains Patri-Perfection as to free growing and habit; strong and bushy, beginning to bloom quite early in the Spring and continuing very late; tube and sepals are bril. liant; deep scarlet, thick and leathery in texture; corolla is very large, double and pure white. Price, 50 cents per dozen: $\$ 3.00$ per hundred.

Mme. Bruant-A fine, large, rounded corolla with strongly recurved sepals. The corolla is a delicate heliotrope color, suffused with rose, slightly marked and veined with carmine; sepals deep coral red, making a beautiful appearrnce. It is a vigorous grower and of fine graceful habit. This is a de cided new color in Fuchsias. Price, 50c per dozen; $\$ 3$ per 100 .

The Black Prince-A misnomer so far as name is concerned. being of a bright waxy carmine: tube and petals large and broad, with pale green tips; large, open pale pink corolla, a wonderfully symmetrical habit and the best all round Fuchsia we know of. Price, 50 cents per dozen; $\$ 3.00$ per huudred.

Bon Valoure-A remarkable free flowering variety with flowers of very large size. The plant is of compact, symmettical growth, making fine shapely plants in quite small pots. Tube and sepals deep coral red, corolla white, veined and suffused carmine. A distinct and valuable new variety. Price, 50 cents per dozen; $\$ 3$ per hundred. 


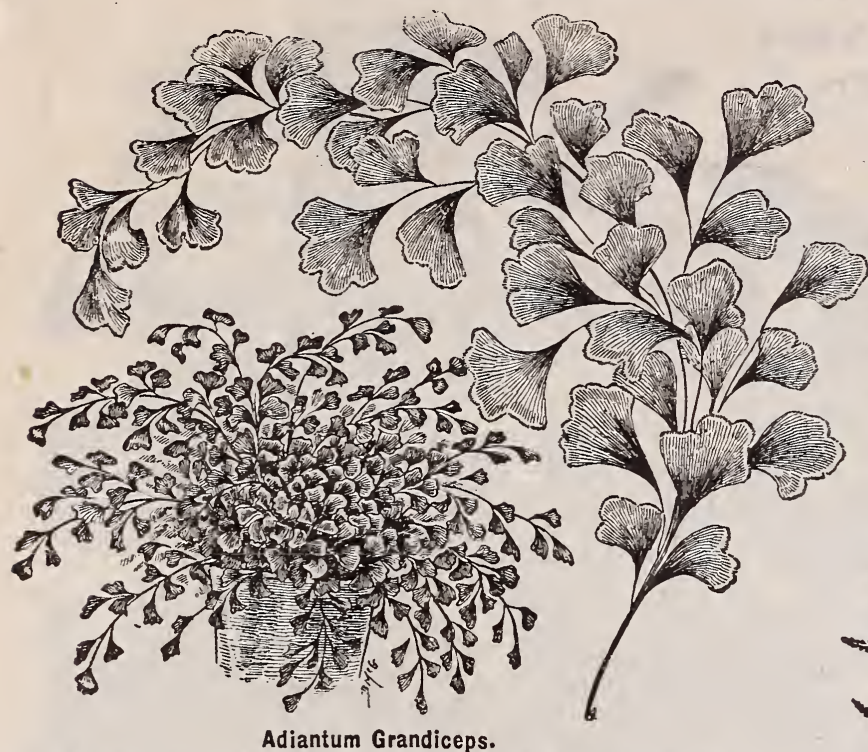

. BEAUTIFUL FERNS..

The Beautiful Maiden Hair Fern. Adiantum Cuneatum Grandiceps-A very beautiful form of A. Cuneatum, having long graceful fronds, with the ends of the fronds developed into bunching-tasseled heads: a distinct and lovely variety. See cut. Price, $50 \mathrm{c}$ perdozen; \$3 per 100.

pediantum Pubescens-Another charming variety of Maiden Hair Fern that is easily grown and verr effective. Heavy long fronds of regularly pinnated and of a lustrous green. Price, $50 \mathrm{c}$ per doz; $\$ 3$ per 100 Blechum 0ccidentalis-A beautiful, strong grown dwarf Fern with fronds of a light green. The young leaves have a charming pink lustre. Price. 60c per dozen; \$4 per 100.

Pteris Cretica Albo-Lineata-A pretty and useful variegated variety, distinctly showing the clear white variegation. A useful and eusily grown Fern. Price, 60c per dozen; \$3 per 100.

Lomaria Glbba-A most desirable species, with very finely divided pinnæ; excellent for table decuration. Price, $50 \mathrm{c}$ per dozen; $\$ 3$ per 10 ).

The Beautiful Silver Fern. Pteris Agyres - A very howy Fern, with variegated foliage; fronds large, light green, with broad band of silver-white down the center of each. Very distinct. We have a large stock of this beautiful Fern, and offer them in three sizes. Price, $50 \mathrm{c}$ per dozen. $\$ 4$ per $100 ; 76 \mathrm{c}$ per dozen, \$6 por 100; \$1 per dozen, \$8 per 100.

Adiantum Grandiceps.

The Boston Sword Fern, Nephrolepsis Exaltata Bostoniensis-A variety which originated in the vicinity of Boston, where it has been in popular favor for $a$ number of years under the name of Boston Fern. In the vicinity of Boston no other plant is used so exten. sively as this graceful Nephrolepsis, which differs from the ordinary Fern in having much longer fronds, which frequently attain a length of four feet. These fronds arch and droop over very gracefully, on account of which it is frequently called the Fountain Fern. Price. 21/2-inch pots, $50 \mathrm{c}$ per doz., $\$ 4$ per 100; $31 / 2$-inch pots, $\$ 1$ per doz., $\$ 8$ per 100
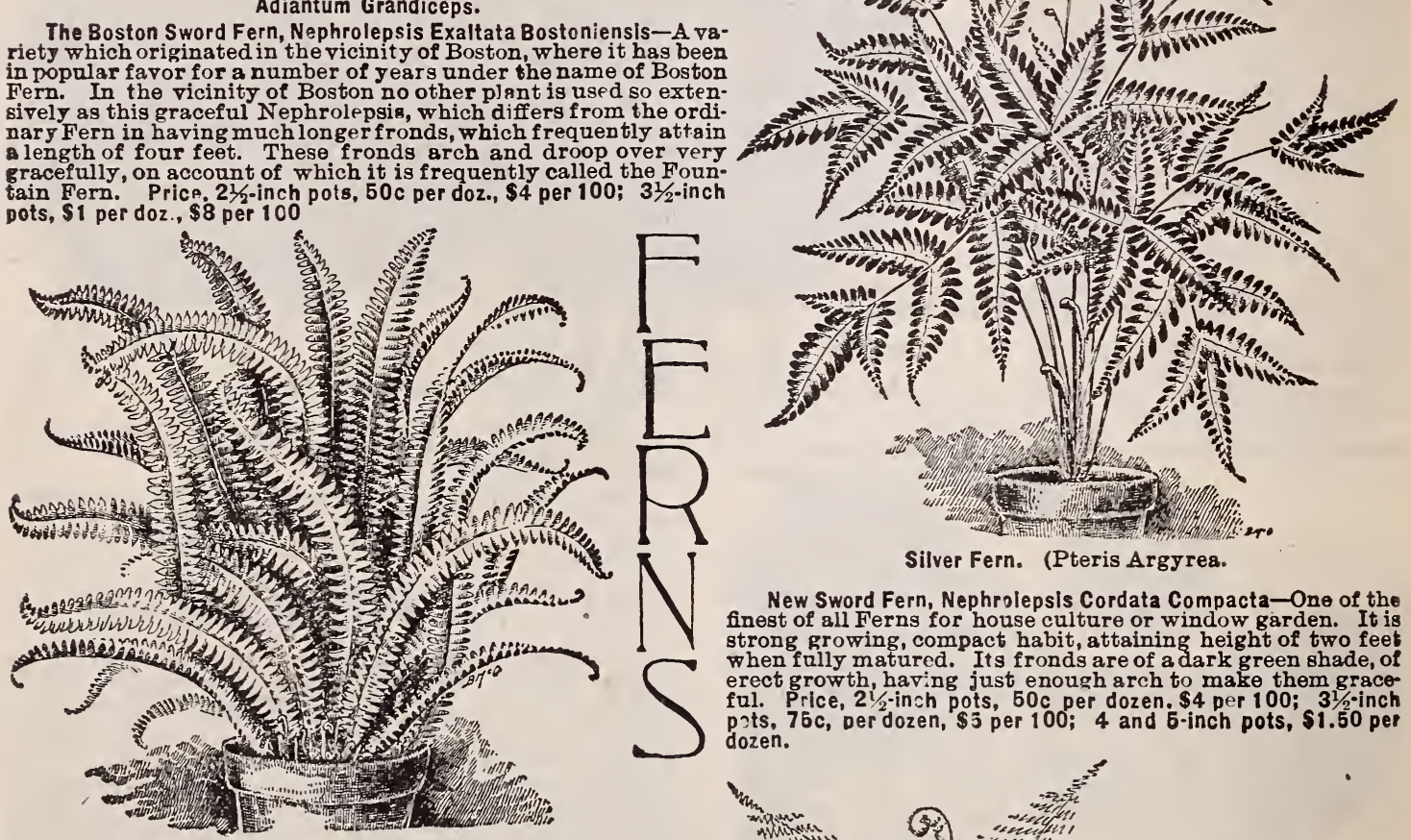

Silver Fern. (Pteris Argyrea.

New Sword Fern, Nephrolepsis Cordata Compacta-One of the finest of all Ferns for house culture or window garden. It is strong growing, compact habit, attaining height of two feet when fully matured. Its fronds are of a dark green shade, of erect growth, having just enough arch to make them graceful. Price, $21 /$-inch pots, $50 \mathrm{c}$ per dozen. $\$ 4$ per $100 ; 31 \%$-inch p?ts, $76 \mathrm{c}$, Derdozen, $\$ 5$ per $100 ; 4$ and 6 -inch pots, $\$ 1.50$ per pats, 7
dozen.

Sword Fern, Cordata Compacta.

The Beautiful Gold Fern of Australia, Gym. nograma Alstonii-This exceedingly novel and beautiful variety bears leaves of a dark green on the upper surfaces, while dark green on the upper surfaces, while the under surfaces are richly cnvered is a most siriking plant when viewed from beneath, while frum a hove th th furling young fronds nice $21 / 2$ inch pots, $75 \mathrm{c}$ per dozen, $\$ 5$ per 100.

Pteris Tremula-(Shaking Fern.) The foliage of the Pteris varieties is large; very graceful. The slightest movemint of the air shakes the leaves of this kind, which we recommend more thun any other for bouse cult ure, fitc. It g-nirs other for house cult ure, ftc. Th the lives readily and very fact. K ap the leaver and sprinkle slighily every warm day. A fine stock of nice plants at the fnllowing prices: $40 \mathrm{c}$ per doi en, $\$ 3$ per $100 ; 60 \mathrm{c}$ per dozen, $\$ 5$ per 100 ; $\$ 1$ ver cozen, \$8 per 100.

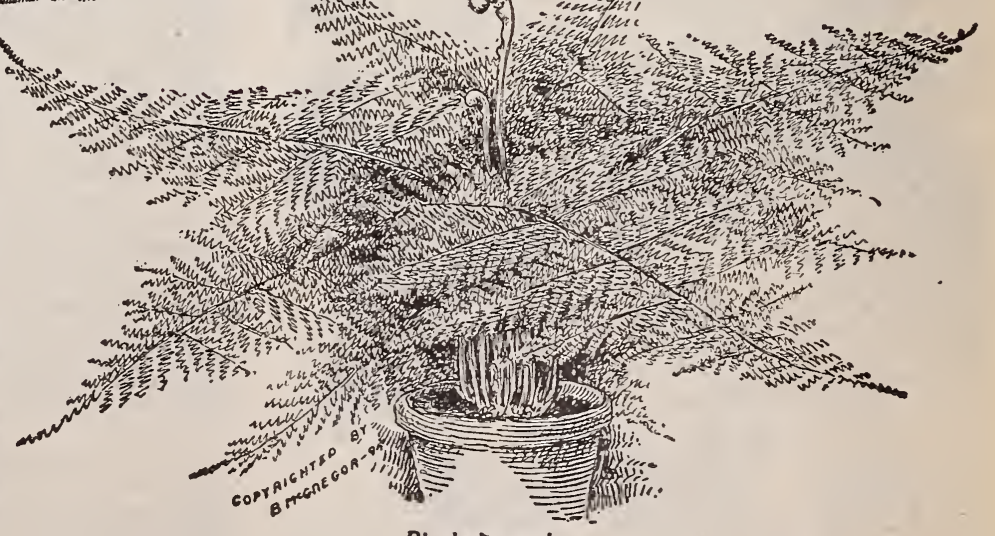

Pteris Tremula. 


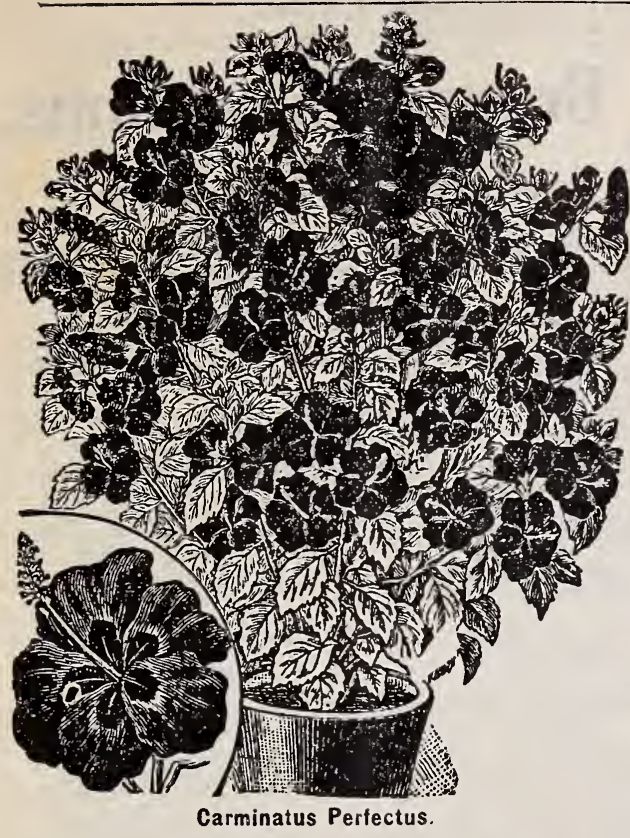

\section{CHINESE HIBISCUS.}

7 ARGE Growing tropical plants with very glossy foliage. The plants, under the hotest sun, produce enormous flowers, in great numbers a d make noble specimens. They can be grown in tabs and $k$ ept average five or six inches in diameter, and are gorgeously colored. Price, 40 cents per dozen: $\$ 3$ per hundred.

Auriantica-Large, double, orange-colored flowers; an early and profuse bloomer.

Decorus-Foliage very large and lobed; flowers enormous on lone stems, of a rosy carmine-color; stamens and pistils very showy; the stigma is large, circular and golden yellow.

Collerii-A remarkably new and distinct variety, introduced from the South Sea Islands. Flowers of a buff-yellow, with a crimson-scarlet base, and peculiarly handsome.

Carminatus Perfectus-Full, round flower of perfect shape, and of a rich, soft;carmine-rose, with a deep crimson eye. A beautiful freeblooming variety.

Copperii Tricolor-This variety is mostly grown for its variegated follage, the young shoots having all shades of color from a pure white to deep red, and various shades of green ; flowers single crimson.

Sub Violaceous-Flowers of enormous size, of a beautiful carmine, tinted with violet; probably the largest flower of the Hibiscus family.

General Courtigis-A very grand, large-sized flower, single, light carlet, very showy.

Grandiflora-Rich, glossy foliage, blooming profusely through the summer, lite rally covering the plant with scarlet.crimson flowers.

Miniatus Semi-Plena-Large, semi-double, brilliant and attractive, bright vermilion-scarlet; ought to be in every garden.

Versicolor-A variety combining in its flowers all colors of the whole family, being handsomely striped crimson, buff, rose and white.

Double Hibiscus Zebrinus-Petals Fcarlet, edged and striped with creamy-yellow and white. Vury uulque variety.

\section{CROWN OF THORNS.}

\section{(Euphorbia Splendens.)}

A which are covered with stout, sharp spines nearly an iuch long. There is a tradition that, this plant furnished the material for the "Crown of Thorns" us d in th, divine trazedy. The foliage is bright green and the fluwers are a beauriful scarlet-pink, very pretty when in bloom. Price, $\mathbf{6 0}$ cents per dozen; $\$ 4$ per hundred.

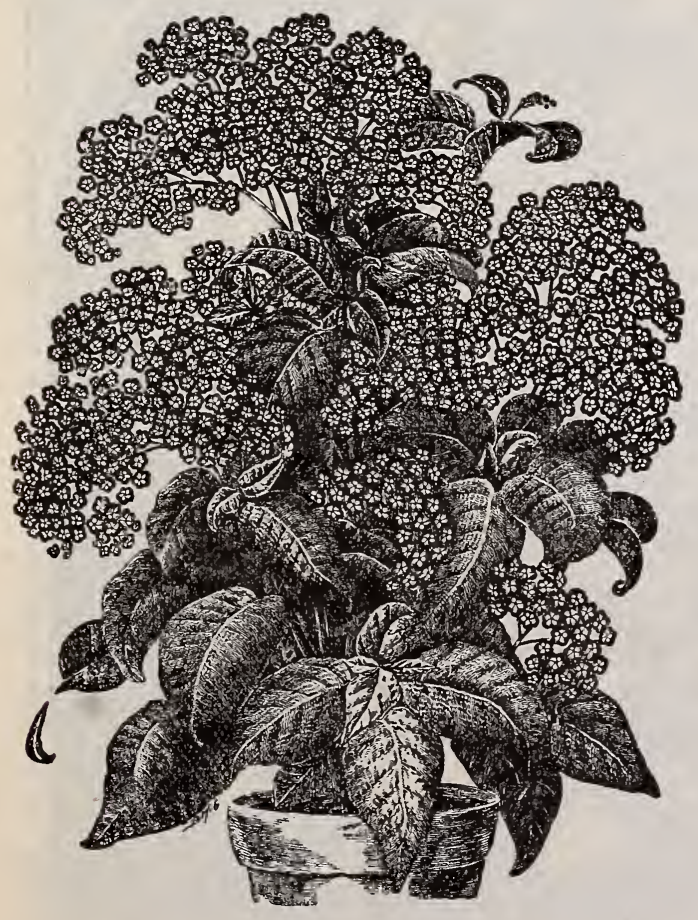

Ciant Helitrope. Picciala.

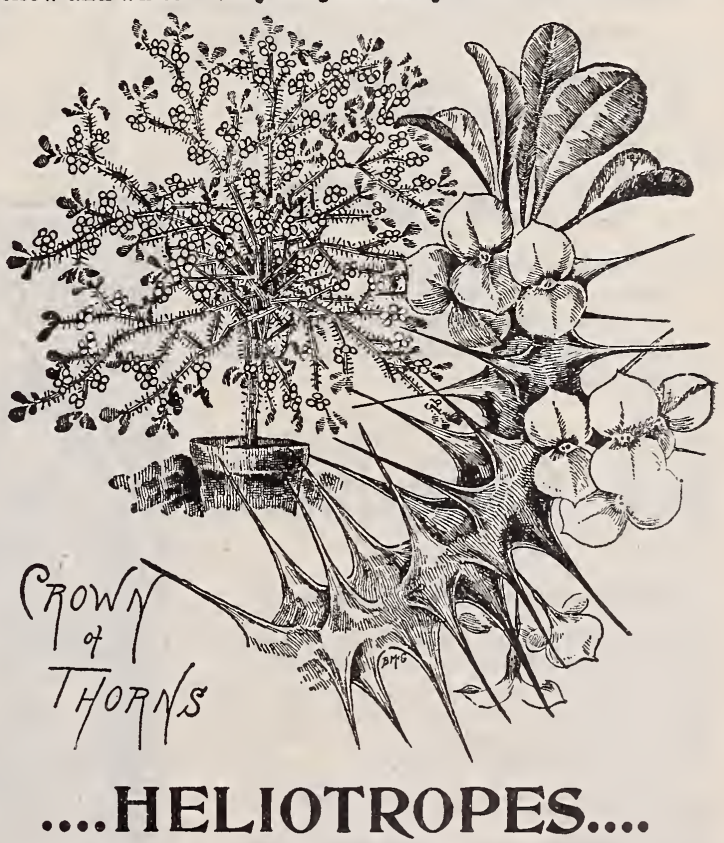

Standard Kinds. Price, 40c Per Doz.; \$2.50 Per Hundred.

Florence Nightingale-A splendid market kind; healthy, flowers bright lavender, good trus

Madame de Blonay-Fine, large, strong foliage, very large trusses of pure white flowers.

Mrs. David Wood-It is a very nice, distinct Heliotrope, with large trusses of violet flcwers of light center.

Albert Deleaux-Foliage is a bright golden yellow, marked slightly with delicate green.

Madame Bruant-Immense panicles of very large flowers, rich purple, with large, white eye.

Mme. A. Carriere-It has a very large white eye,contrasting with the bright bule; panicles very large, semi.d warf, $t x$ tremely free. Fleur de Ete-A splendid new sort, having panicles of bloom of the largest size; beautiful shade of blue, shading to white at the center.

Picciola-Rosy-violet, indeed almost red, with a distinct white center, showing upright growth, producing immense head of flowers well above the foliage.

Oueen of the Violets-Color of the deepest violet-purple, with large, almost. whit $\theta$ eye, and rery fragı ant. 


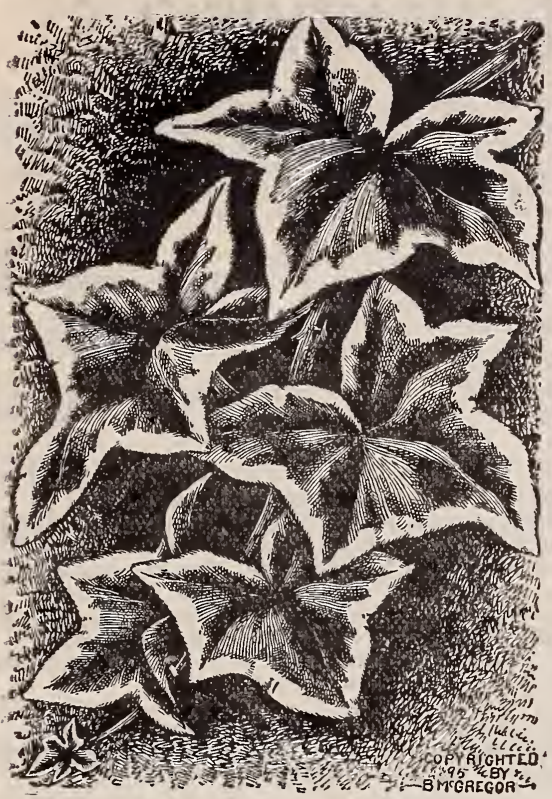

Silver-Leaved Ivy Geranium, Le Elegante.

The Beautiful Variegated Silver=Leaved Ivy Geranium,

\section{LeElegante.}

This varlety, always scarce, has brilliant green foliage, with a creamy - white band, sometimes changing to pink; pure white flowers. Price, $50 c$ per dozen; $\$ 4.00$ per 100.

$$
\text { * } \infty
$$

\section{Ivy Geraniums.} NEWER SORTS.

Price, 50 cents per dozen; $\$ 3.00$ per 100 .

Camille Doucet-Flowers large, rosy-sal ${ }^{-}$ mon, lightly marked red on each petal.

Garden's Glory-Fine, bright scarlet; the best of its color, perhaps; bold, full flower ; free grower and bloomer, and one of the best generally useful of Ivies.

La Foudre-Flowers quite donble and of bright orange-scarlet color.

Incomparable-(Syn. Remarkable.) Trus. ses very large, florets immense and very regular in form; quite full; the color is an exquisite shade of rosy-carmine. No finer.

Jeanne d'Arc-Flowers very large and double; of the purest white; fine habit; free flowering. The only double white in this class.

La Rosaire-Flowers very large and perfectly double, making a lovely rosette in shape; color of the most delicate pink shade, and exceecingly attractive.

Count Horace du Choiseal - Flowers of grand size, two inches across, petals imbricated, pale plush, bordered with salmon; very free flowering.

Souv. Chas. Turner-One of the handsomest Ivy Geraniums ever introduced : florets two and $a$ half inches in trusses six inches across. The color is a deep, bright pink, approaching scarlet in color, the upper petals seathered maroon; quite double.

\section{Golden Bronze Geraniums.}

\section{Price, 50c per Dozen: $\$ 3.00$ per 100 .}

Bronze Bedder-Foliage bright golden-yellow with a broad zone of a deep chestnut-brown, scarlet blossoms. This variety stands the sun exceed ingly well.

Black Hawk-Golden-yellow, with broad, red zone, red flowers.

Bismarck-Foliage, yellowish-green, with narrow zone of deep chocolate; flowers salman, tipped white.

Exquisite-Large chocolate zone, large golden-yellow center; edges variegated; flowers salmon.

Fanny-Golden-yellow foliage, with a bright red zone; large trusses of charming peach-colored blossoms. Extra.

Magician-Foliage dark-green, with greenish-yellow disc. Flowers orange-scarlet, and foliage as fine as on some of the golden tri-colors.

Marshal McMahon-Golden-yellow, with a zone of dark chocolate, fine large foliage; a splendid bedder.

Zulu-Bright yellow leaf, with very deep chocolate, almost black zone decidedly the flnest of the class.
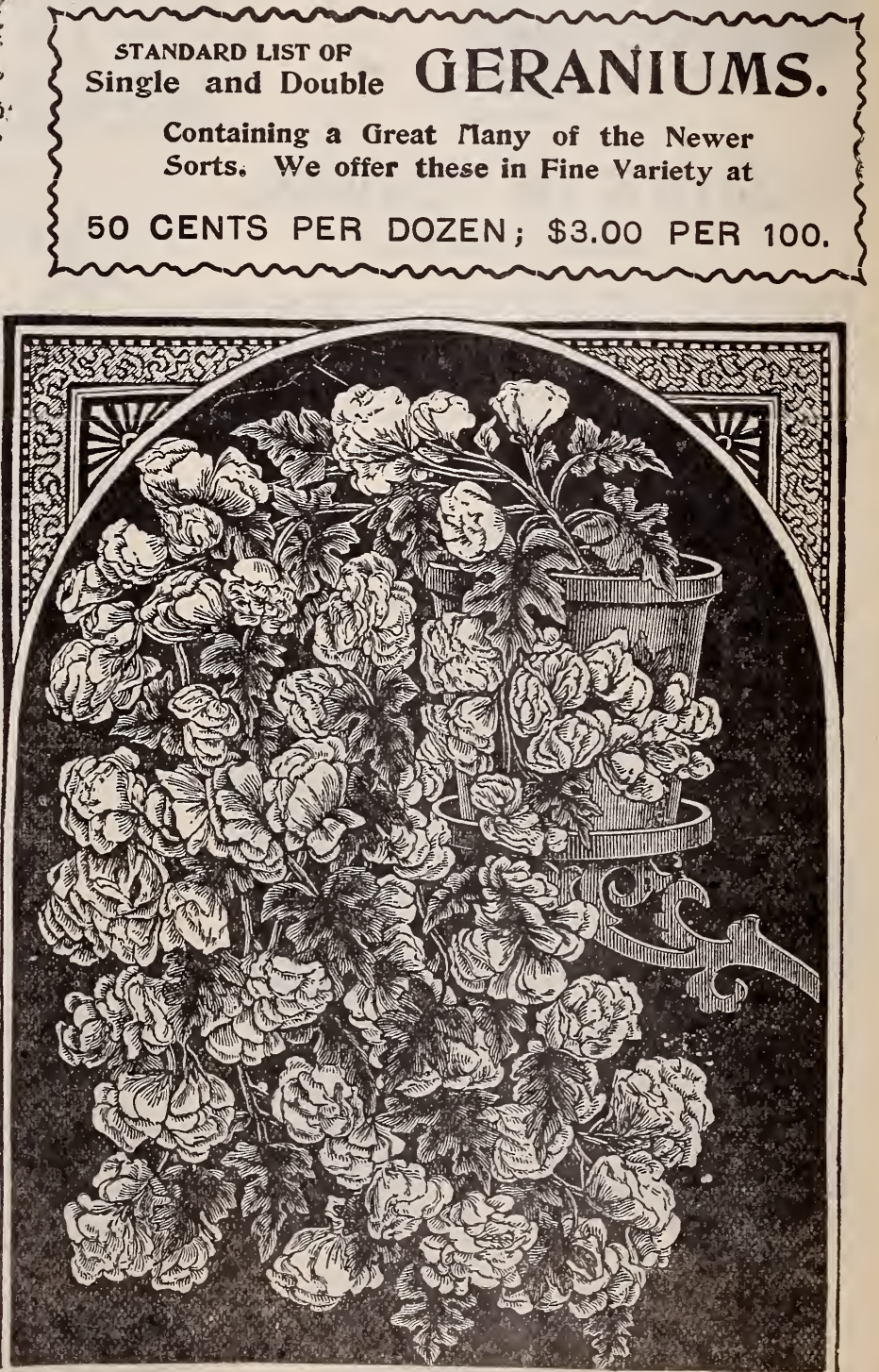

Jeanne de Arc. 


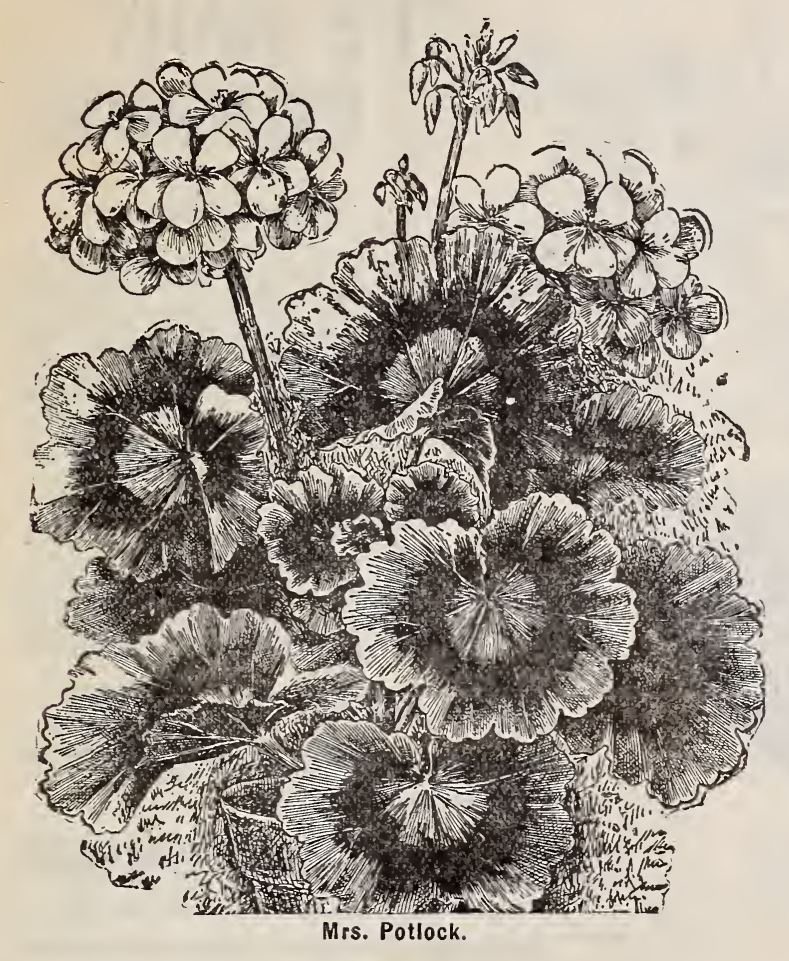

TRI-COLORED * *

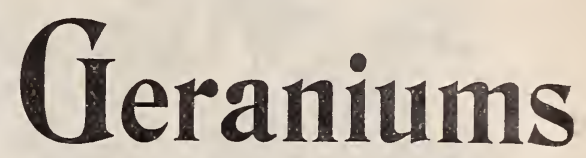

\author{
Mrs. Pollock.
}

Bright bronze-red zone, belted with crimson and edged with golden-yellow. A beautiful variety. Price $10 \mathrm{c}$ each; $75 \mathrm{c}$ per dozen; $\$ 5 \mathrm{pcr}$ hundred.

\section{Prince Silver Wings.}

This is probably the most attractive of any of the tri colors and makes a very symmetrical plant, The color of the foliage is bright green; yellow and white edge, crim son zone. Price, $10 \mathrm{c}$ each; $75 \mathrm{c}$ per dozen; $\$ 5$ per hundred.

\section{Silver Pheasant.}

Lustrous green foliage with soft creamy white edge, quite distinct. Price, $75 \mathrm{c}$ per dozen; $\$ 5$ per hundred.

\section{Lord Napier.}

Center of leaf light green, with heapy chocolate bor der, suffused with carmine and golden-yelluw edge. Price, 75 c per dozen; $\$ 6$ per hundred.

\section{Glen Eyre Beauty.}

Bright chocolate zone, belted with rosy-carmine, pure white margin. Price, $76 \mathrm{c}$.per dozen; $\$ 5$ per hundred.

\section{Madame Salleroi.}

It makes a round, pretty plant, about one foot high and wide, foliage bright green, edged with pure white Price, 50 c per dozen; $\$ 4$ per hundred.

\section{PELARGONIUMS,}

\section{.. OR ..}

\section{Lady Washington Geraniums.}

These are more commonly known as Lady Washington Geraniums. The flowers have deep blotches on the upper petals and bright spots on the lower ones. When in bloom during the months of May and June they are very beautiful and ornamental, either as pot plants or in the garden. Although their time of blooming is short, their great beauty while in flower makes them very desirable.

\section{Mrs. Robert Sandiford.}

This grand double white variety is one of the finest novelties of the year. The flower is of large size, well doubled, beartifully ruffled along the edges of the petals and of glistening snowy $\cdot$ white color. Price, $75 \mathrm{c} \mathrm{per}$ dozen; $\$ 6$ per hundred.

\section{Victor.}

This variety is grown by the tens of thousands for the New York market, and finds a ready sale. It is a bright cherry-pink, white at base of petals. Petals are crimson maroon. Price, 50c per dozen; $\$ 4$ per hundred,

\section{Capt. Raikes.}

Large individual flowers of a brilliant crimson, beautifully marked and veined, fine handsome foliage and steady growth. We would heartily recommend this variety. Price, 60c per dozen; \$4 per hundred.

\section{Kingston Beauty.}

This is one of the best varieties; large, pure white, with beautiful plum-eolored center that gives it a unique appearance. Price, 60 c per dozen; $\$ 4$ per hundred.

\section{Dr. Andre.}

A fine, strong grower; light, carminepink, marked and veined, purplish-crimson. Price, 60c per dozen; $\$ 4$ per hundred.

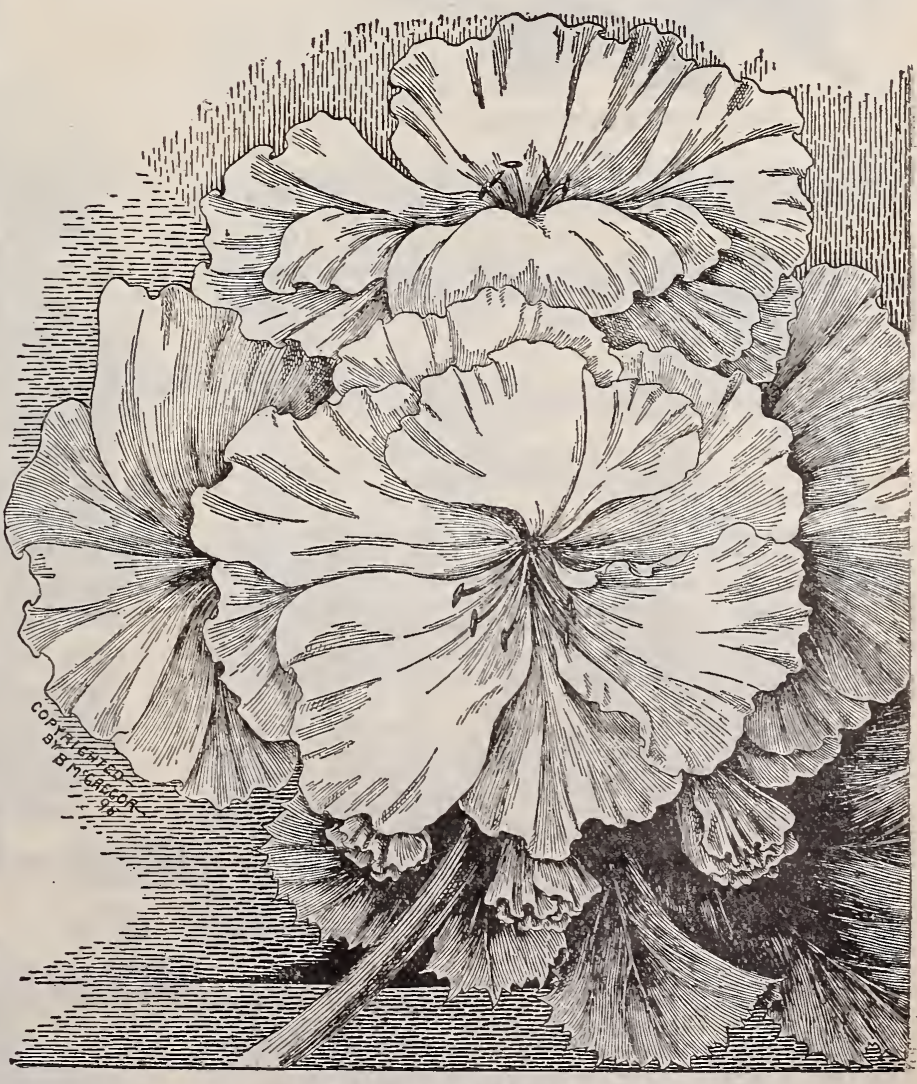

Mrs. Robert Sandiford. 


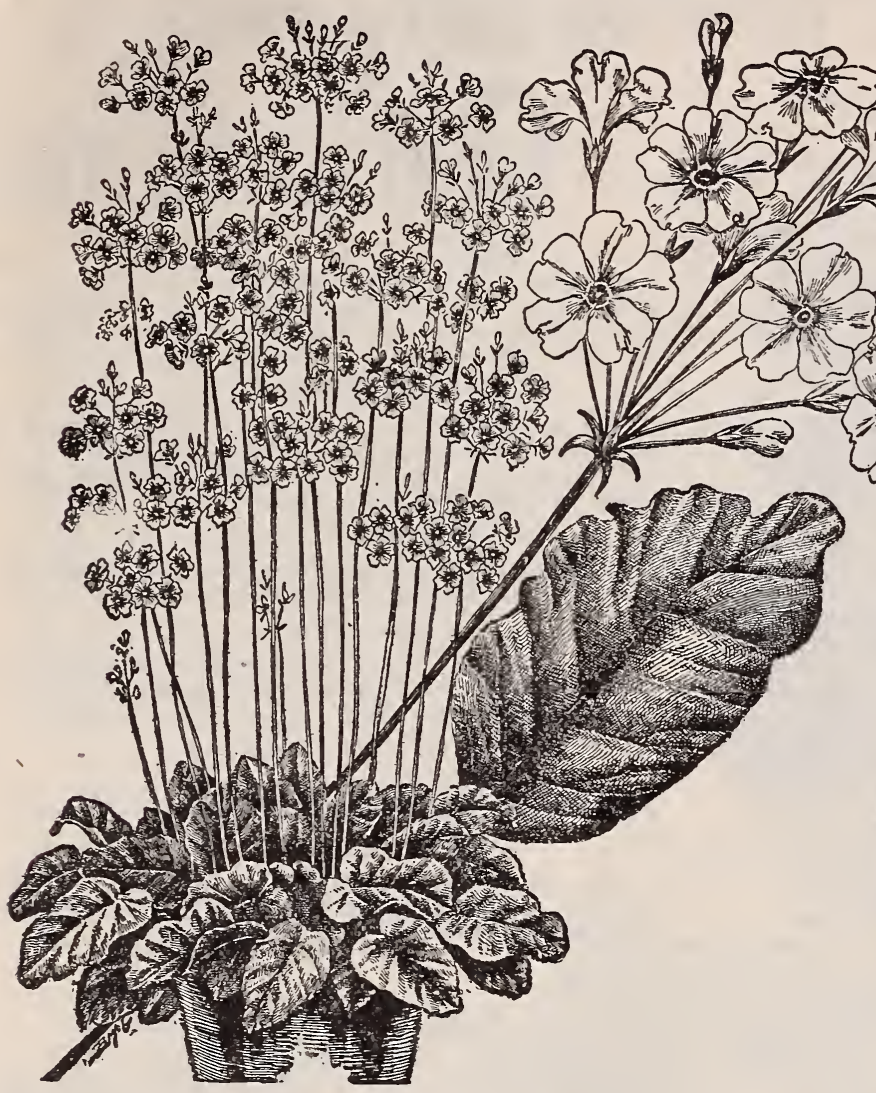

\title{
THE BABY PRIMROSE.
}

\author{
(Primula Forbesi.)
}

It is a wonderfully free-blooming plant. commencing to flower as soon as born. It is raised from divisions; also from the seed, though the latter method is unadvisable owing to the uncertain and variable character of the seedlings. It forms a dense rosette of somewhat fleshy leaves, frum which spring the flowering stems, twelve fifteen and even twenty inches tall supporting three tiers or whorls of dainty flowers of a delicate rosy-lilac, with eye of pure gold. The flowers are not more than half and inch in diame. not more than half and inch in diamogreat abundance that a few plants present a dense mass of bloom, which continues without interrup. tion and with increasing vigor from September until June. Nice plants, 40c per dozen; \$3 per hundred.

\section{IMPATIENS SULTANA.}

The Sultan's balsam ; Sultana and Royalty,two fine distinct colors. Price, 60 cents per dozeni $\$ 4.00$ per hundred.

\section{MESEMBRYANTHEMUMS.}

Price, 50 cents per dozen; $\$ 3,00$ per hundred.

Cordifolium.-Variegeted foliage. Pink flower: White and Pink-Flowery ; fine for bedding.

The Baby Primrose.

\section{PRIMTROSE, SINGLE CHINESE.}

We maks a specialty of Chinese Primroses, procuring them from the finest strains in this country and Europe They are large in size and beautifully fringed, as well as rich in color-not the pale, sickly tints so often seen. Price, $50 \mathrm{c}$ per dozen, $\$ 3$ per 100 .

\section{JASIIINES.}

Grandifiorum-(Catalonian Jasmine.) Flowers pure white, star-shaped, of exquisite fragrance. Price, $6 \mathrm{c}$ each; $50 \mathrm{c}$ per dozen; $\$ 3$ per 100; 4-inch pots, strong, 75 c per dozen; $\$ 5$ per 100 .

Gracillimum-A new Jasmine, and remarkable for its freedom of bloom. Beautiful pure white flowers, borne in clusters. Delightfully fragrant. In bloom from October to February. Price, $60 \mathrm{c}$ per dozen; $\$ 4$ per 100 ; 4 -inch pots, 75 per dozen; $\$ 6$ per 100 .

New Jasmine, Maid of Orleans-A very attractive new sort, with good size double flowers, blooming profusely all Sum mer, shining, pale-green foliage. We predict for it a rapid sale, as it is much easier to handle than other Cape Jasmines, and, as a whole, more desirable. Price, 31/2-inch pots, $\$ 1$ per dozen; \$8 per 100; 21/2-inch pots, $6 \mathrm{c}$ each; 50 c perdoz; \$4 per 100

Revolutum-A strong, climbing plant, with glossy leaves and single, deep yellow, fragrant blossoms. A beautiful plant, and easily grown. Almost hardy in this latitude. Price, 21/ inch pots, $60 \mathrm{c}$ per dozen; $\$ 4$ per $100 ; 4$-inch pots, $75 \mathrm{c}$ per dozen; 56 per 100.

Grand Duke-This Jasmine is very easily grown, even small plants bear a profusion of very double creamy-white flowers, having a delicious perfume. It is a magnificent plant, and will become one of the most valuable and popular pot plants when it becomes better known. It can be stored in a dry cellar in Winter. Price, 60 c per dozen; $\$ 5$ per 100 ; 4-inch pots. \$1.25 por dozen, $\$ 10$ per 100 .

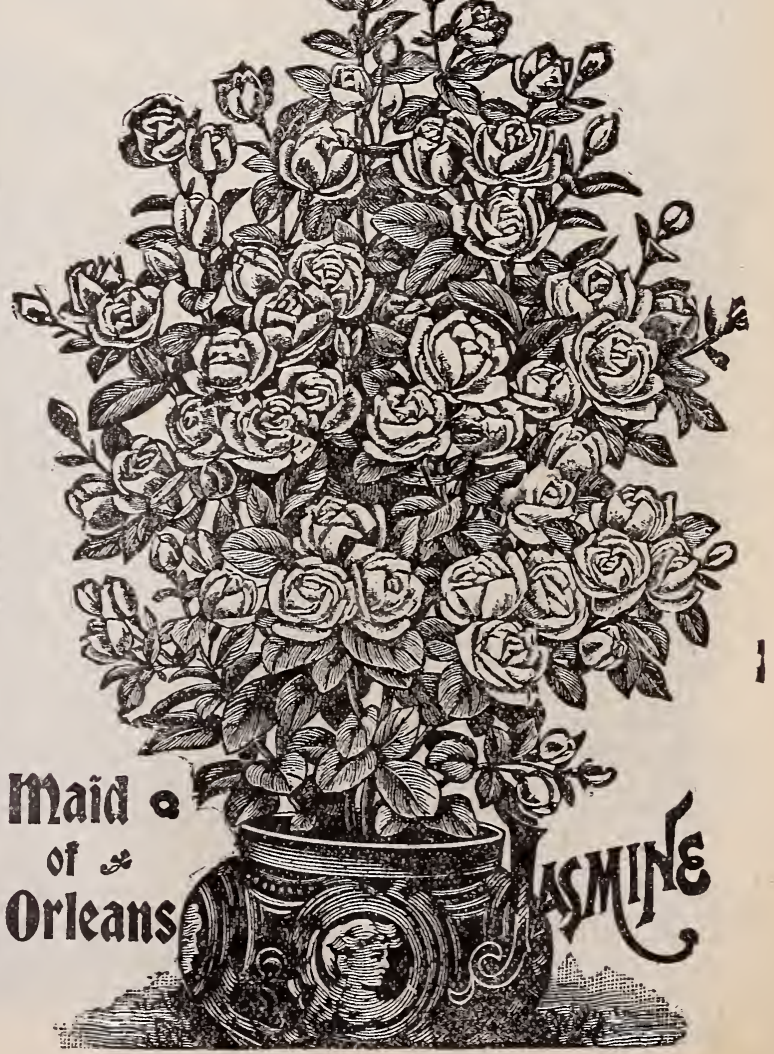




\section{Mexican Primrose.}

Rosea-The pink Mexican Primrose. A splendid variety. Price, 40 cents per dozenı $\$ 3$ per hundred.

Apple Blossom-New. The beautiful blush Mexican Primrose. Color of apple blossom." A very pretty variety. Price, 40 cents perdozen; $\$ 3$ per hundred.

\section{Manettia Bi-Color.}

A rapid and beautiful new climber. The flowers are from an inch to an inch and a half in length, of the most intense scarlet, shading into flame, tipped with bright goldenyellow, and are covered with a thick scarlet moss. This variety must not be confounded with the old Manettia. Cordifolia, as it is far superior to the old variety. Price, 50 cents per dozen; $\$ 3$ per hundred.

\section{Paris Daisies=- Marguerites.}

Very profitable for cut flowers. Always in demand and so easily handled. Price, 40 cents per dozen; $\$ 3$ per hundred.

White-Best white, having a ray of white petals around a salmon disc. Splendid for cut flowers.

Yellow-(Etoile de Or.) A golden yellow variety of fine form and large size. Prized for corsage bouquets.

Blue Daisy-(Agathea Cœlestis.) Daisy shaped flowers of intense blue, with yellow disc for center. Price, 40 cents per dozen; \$3 per hundred.

\section{Lophospermum Scandens.}

A handsome climbing plant of rapid growth, with heartshaped leaves and rose-colored, Gloximia-like flowers. Its rapid growth and fine foliage, with its beautiful flowers combine to rmake it one of the best plants for covering any unsightly objeet, or for large vase on the lawn. For a climber on the veranda it has no equal. Price, 40 cents per dozen; $\$ 3$ per hundred.

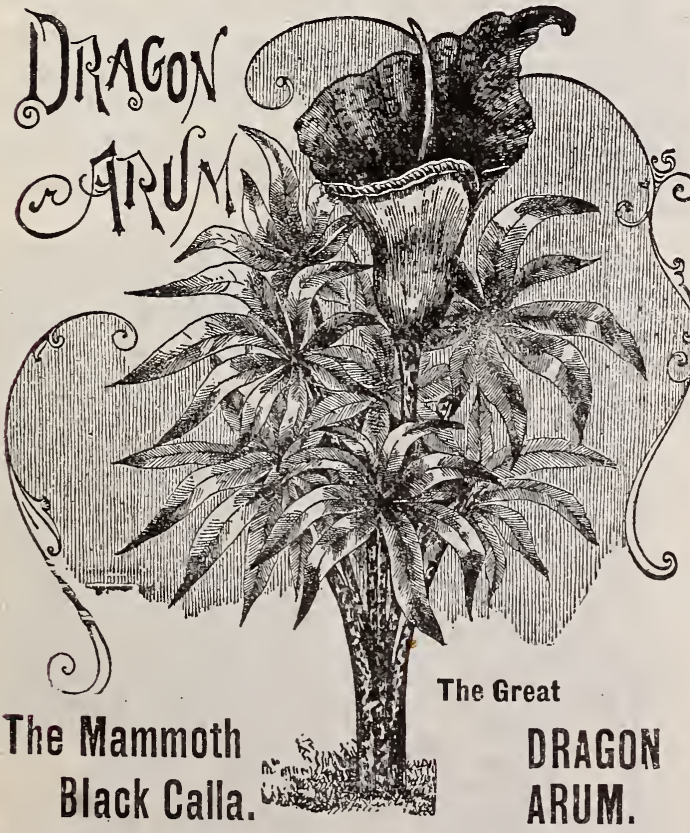

The plant has the honor of producing the largest flower of any plant that is hardy in this country. They are simply enormous. The leaf stems and fiower stock are all spotted; upon the top of the latter opens a flower of gigantic size and curious color. On the outside it is of a light green color, while the inside is of a deep red purple, glistening beauti fully in the sun with a satin sheen. The spadix in the center of the flower is of a glossy purple black color. As will be seen from the cut, the plant resembles a palm in general sppearance. Price, $\$ 1$ per dozen; $\$ 8$ per hundred.

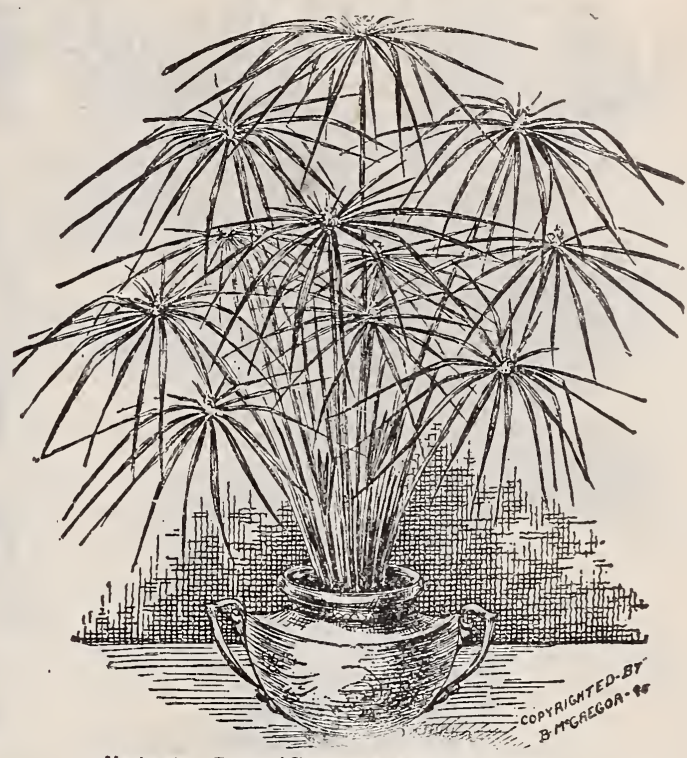

Unibrella Plant (Cyperus Alternifolias.)

UMBRELLA PLANT.

An ofnamental grass, throwing up stems about two feet high, surmounted at the top with a whorl of leaves, diverg. ing horizontally, giving it a very curious appearance. Splen. did for the center of vases or as a water plant. Price, $50 \mathrm{C}$ per dozen; $\$ 3$ per hundred.

\section{IPOMCEA NOCTIPHYTON.}

The True Evening Glory or Moon Flower.

As a climber of rapid growth to cover arbors, veranda. old decayed trees or walls, it has no superior. Flowers pure white, five inches in diameter, moon-like, and, as they ezpand at night, have a striking effect. Price, 6 cents each; $40 \mathrm{c}$ per dozen; $\$ 3$ per hundred.

IPOMGEA LEARII, The Blue Mloon Flower.

From Ceylon. A handsome, quick growing perennial climber. Often filowers in bunches of a half dozen; the individual flowers are trumpet-shaped, about four inches across, of a rich, violet blue, with fine purple rays. Price, 50 each; $40 \mathrm{C}$ per dozen; $\$ 3$ per hundred.

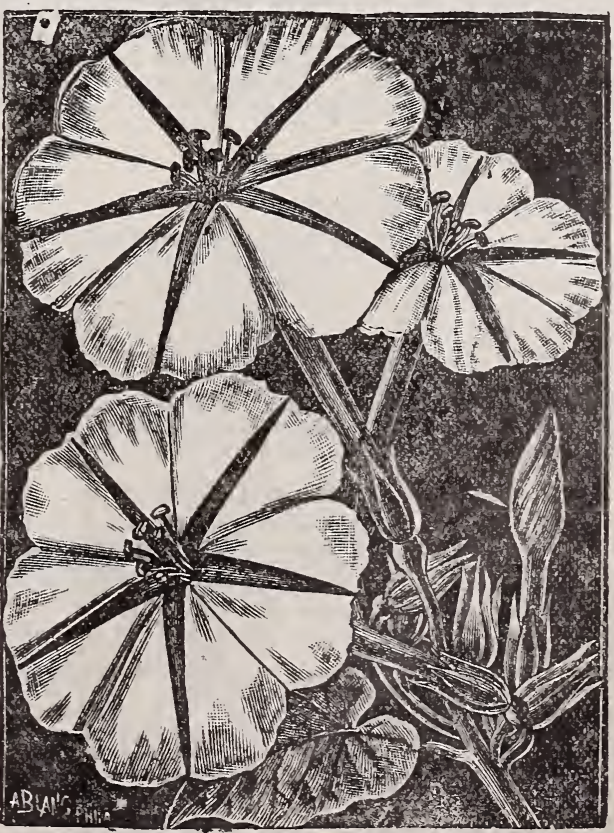

The True Moon Flower (Ipomæa Grandiffnra.) 

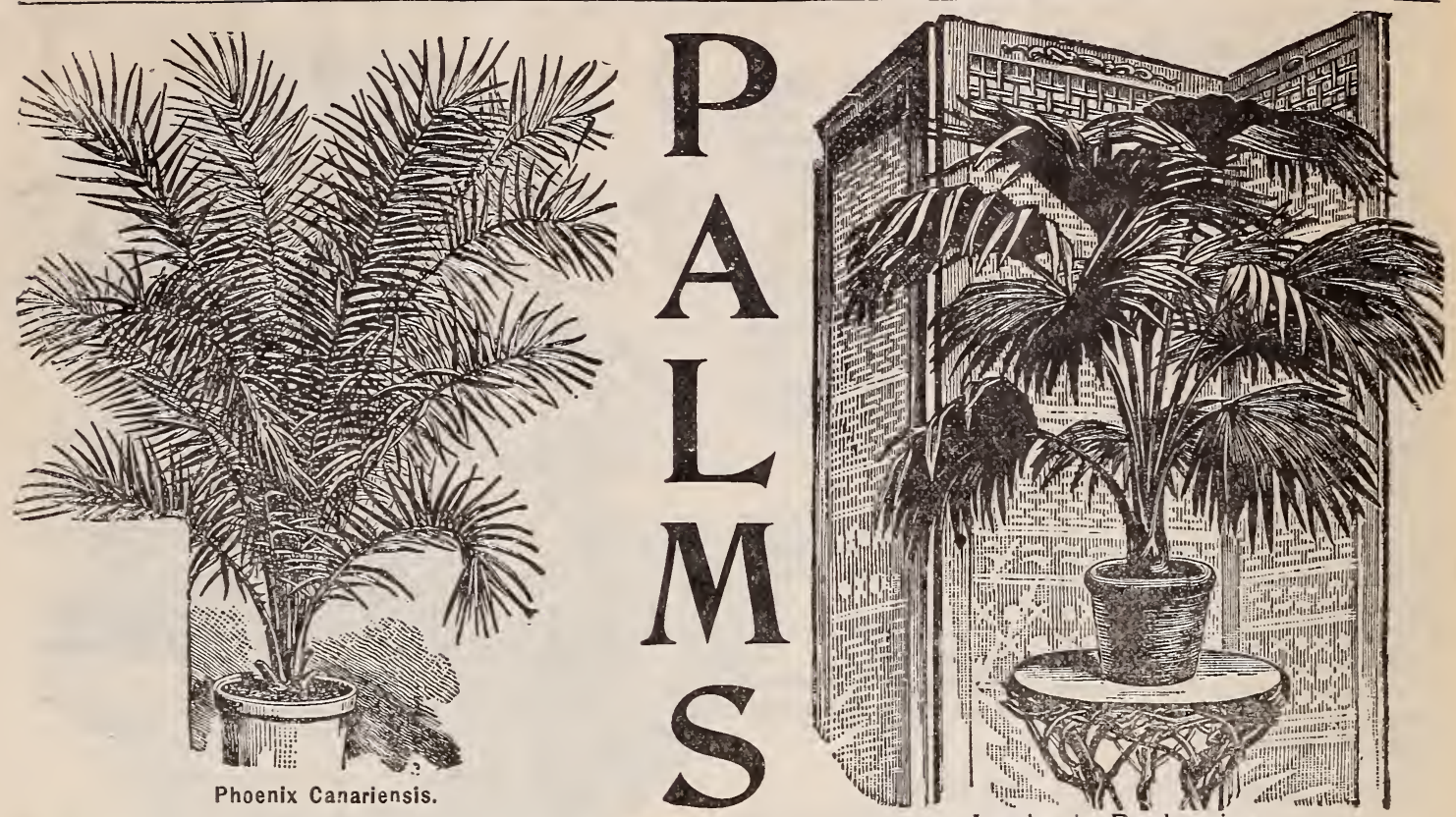

\section{PALMS...}

We offer a list of the more easily handled Palms. They are nice, thrifty, clean stock, and when potted will soon bring four or five times the price at which they are here offered.

NOTE-It may be well to state here that in mentioning the number of leaves to each size, it has reference to embryo, not character leaves.

\section{PHOENIX}

\section{CANARIENSIS.}

(The Canary Island Date Palm.) No other Palm has gained so speedily in public favor the last few years as this handsome babitue of the Canary Islands. This Palm belongs to the pinnate class, which means that its branches are feather-shaped. These branches are long, gracefully arched, and, as the picture shows, are borne in luxuriant abudance. The color of the foliage is dark, glossy-green. The Canary Islands Date Palm is of rapid growth, and soon attains large size. Price, 21/2-inch pots, 12 inches, 4 and 5 leaves, $50 \mathrm{c}$ per dozen; $\$ 4$ per 100; $3 \frac{1}{2-i n c h}$ pots, 12 to 14 inches, $75 \mathrm{c}$ per dozen; $\$ 6$ per 100.

\section{KENTIA}

\section{FOSTERIANA.}

This is one of the finest pot plants imaginable, and the easiest to grow of any of the Palm family. Being almost hardy it is not injured by slight changes in the the tempera. ture and its stiff, glossy leaves enable it to stand the dry, hot air of the living room without injury. The leaves are a deep, glossy-green, fan shaped, split deeply into segiment. This is, without exception, the most hardy of its class. It is very graceful for table decoration. Scarcely has its equal. Price, $21 \%$ inch pots, 8 to 10 inches, 3 leaves, $\$ 1.50$ per dozen: $\$ 10$ per 100; 3 .inch pots, 12 inches, 3 and 4 leaves, \$2 perdozen; \$15 per 100 ; 4 -inch pots, 12 to 18 inches, $\$ 3$ per dozen; $\$ 20$ per 100 .

\section{NEW OTAHEITE DWARF ORANGE.}

Among the new varieties of oranges that have been re cently introduced from Japan and other countries, there is one dwarf free-flowering variety, which is suitable for pot cultnre, and which with anyone proves one of the most desirable pot plants it is possible to possess. We refer to the Ja panese Otaheite While it will grow three or four feet high and branch freely, it is not an uncommon thing to see little cutting plants five or six inches high full of bloom, and eve bearing one or two medium-sized oranges. The fruit at their best are not more than half the size of an ordinary orange, but are very bright and beautiful in color, delicious in quality; but it is for its flowers more than its frnit which com mends it to general cultivation. When it blooms it is so full that it seems to be all flowers. The pure waxy-white blossoms emit a delicate yet powerful fragrance, which is surpassed by no other flower. Price, 21/2.inch pots, $40 \mathrm{c}$ per dozen; $\$ 3$ per 100; 4 -inch pots, $\$ 1$ per dozen; $\$ 8$ per 100 .
Latania Barbonica-The well-known favorite Fan Palm, beautiful in all stages of growth. No plant is more easily grown, and none more tenacious of life, enduring the dust, the cold and heat from open windows, and gas-heated air of our dwellings. The demand for this particular kind is perhaps five times that of any other. We offer them to you at the following low prices;

Latania Barbonlca-Price, 21/2-inch pots, 6 to 8 inches, 2 and 3 leaves, $40 \mathrm{c}$ per dozen; $\$ 3$ per 100

Latania Barbonica-Price, 3 -inch pots, 10 to 12 inches, 3 to 5 leaves, 50 c per dozen; $\$ 4$ per 100; $\$ 35$ per 1000

Latania Barbonica-Price, $31 / 2$-inch pots, 12 to 14 inches. 4 to 6 leaves, showing character, $75 \mathrm{c}$ per dozen; $\$ 6$ per 100 ; $\$ 50$ per 1000 .

Latania Barbonica-Price, 4-inch pots, 12 to 15 inches, 4 to 6 ieaves, showing character, $\$ 1$ perdozen; $\$ 8$ per 100.

Latania Barbonic -4 and 5 .inch pots, 2 or more character leaves, $\$ 1.50$ per dozen; $\$ 10$ per 100 .

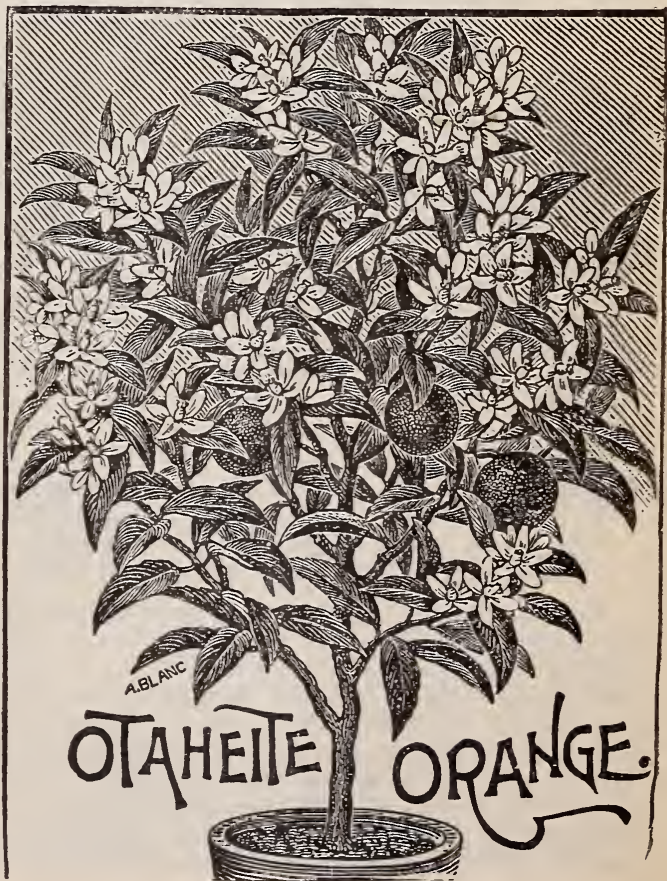




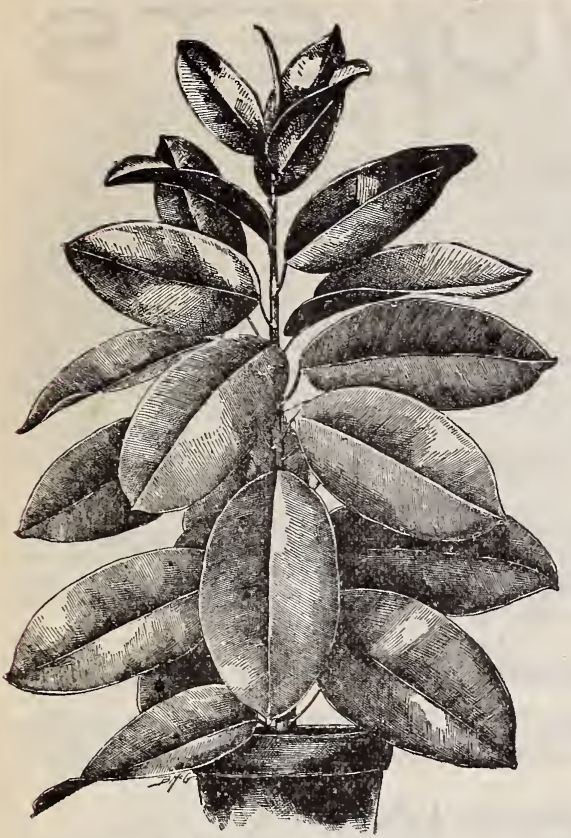

Ficus Elastica-Rubber Plant.

PILEAS... ARTILLERY PLANT.

Price, 5oc Per Dozen; $\$ 3$ Per 100.
...Ficus Elastica...

India Rubber Plant.

Very large, smooth, leathery leaves, evergreen foliage. Generally esteemed one of the finest house plants grown, the plant attaining a large size and tree-shape. Each new leaf is enclosed in a long, coral-red envelope, looking like a great red flower bud. Price, 4-inch pots, top cuttings well leaved, 10 to 12 inches, $\$ 3$ per dozen; $\$ 25$ per $100 ; 5$-inch pots, 15 to 24 inches, fine plants, $\$ 4$ per dozen; $\$ 30$ per 100 ,

STOCK PLANTS OF FICUS.-We are headquarters for Ficus in the West, and carry a large lot of stock plants cut down low, and can make you very liberal prices if you want to go into Rubber Plant growing. Correspondence Solicited.

\section{Swainsonia Galegifolia Alba.}

A native of Australia; extremely graceful : trained at a window or on a trellis, presents a lovely sight of light green foliage, and a splendid profusion of pure white sprays, resembling sweet peas in form. Prfce, 50c per dozen; $\$ 4$ per 100 .

\section{Mesembryanthemum Cordifolium Variegatum.}

Beautiful variegated leaved variety of the common Ice-Plant, wlth starlike purple flowers. A valuable plant for baskets or vases, as its succulent character enables it to stand our hot and dry weather. Price, $40 \mathrm{c} \mathrm{per} \mathrm{dozen;}$ $\$ 3$ per 100.

\section{Mahernia Odorata.}

A pretty plant of spreading habit. Blooms early in the Spring; flowers yellow, bell-shaped and very fragrant. Price, $5 \mathrm{c}$ each; $50 \mathrm{c}$ per dozen; $\$ 3$ per 100.

\section{Leonotus Leonuris.}

(Lion's Tail.)-It blooms from September to December, and if successive propagations are made of it in the late Spring, it can be got to bloom during the Winter months, and it is a most valuable plant either for the sitting room or conservatory. The spikes are upwards of a foot in legnth, and of a vivid orange color. Price, $50 \mathrm{c}$ pe dozen; \$3 per 100.

Muscosa-Artillery Plant, graceful, fern-like foliage and immense numbers of very small flowers, which produce a snapping sound when sprinkled.

Repens-A pretty little plant of drooping or creeping h abit, peculiar moss-like foliage.

Grandis-Until it comes into flower you would never suspect that this belongs to the same family as the "Artillery Plant" (Pillea Muscosa.) It makes a most graceful plant, with large leaves of golden green color.

\section{HARDY CHINESE MATRIMONY VINE.}

The old-fashioned Matrimony Vine was a general favorite more than fifty years ago, but in beauty of flower, fruit and foliage it cannot compare with this superb variety. It is a most vigorous, hardy climbing plant when trained to an arbor, fastened to a fence, attached to a tree, to the side of the house, the pillars of a piazza, or in any location where a hardy, vigorous climber is desired. Price, $40 \mathrm{c}$ per dozen; $\$ 3$ per 100.

\section{SALVIA SPLENDENS.}

The well-known scarlet variety. Price, $40 \mathrm{c}$ per dozen; $\$ 3$ per 100 .

\section{LOPESIA ROSEA.}

Fine red flowering plants, blooming continually from November to April ; fine for cut flowers. Price, $5 c$ each; $50 \mathrm{c}$ per dozen; \$3 per 100 .

\section{GOLDEN LEMON THYME.}

The leaves are curiously edged and variegated with golden-yellow, increasing in brilliancy or color as the Autumn approaches, giving it the appearance of a bed of gold. Price, $5 \mathrm{c}$ each; $50 \mathrm{c}$ per dozen; $\$ 3$ per 100.

\section{DOUBLE PETUNIAS.}

(Dreer's Varieties.) Unsurpassed in brilliancy of colors and the size of flowers. They include all the brightest shades of pink, purple, rose, white, crimson, etc. They have been carefully selected and the most of them are beautifully fringed. Price, 50c per dozen; \$4 per 100.

\section{RUSSELIA JUNCEA.}

One of the finest basket or vase plants known. In growth it produces long, wiry stems, which are virtually leafless. Upon these stems and branches the flowers are borne. They are about the size of a Manettia, long, trumpet-shaped and brilliant scarlet in color. These lovely blossoms a re borne in wonderful profusion during most of the year. Price, strong plants, $50 \mathrm{c}$ per dozen; $\$ 3$ per 100.

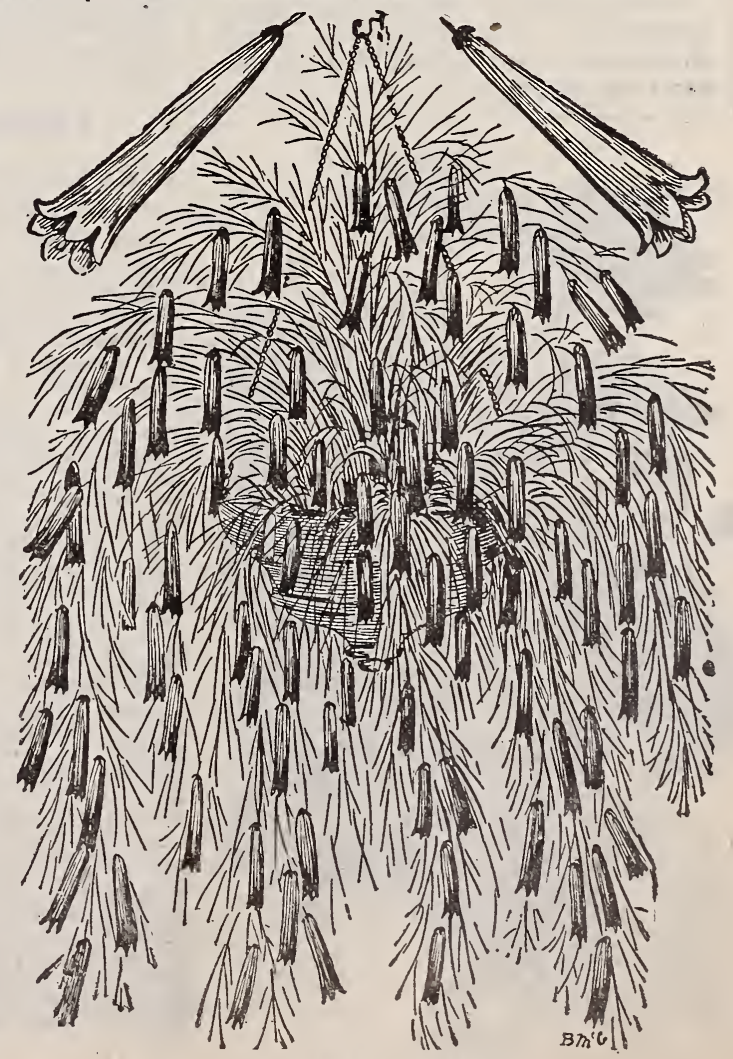

Russelia Juncea. 


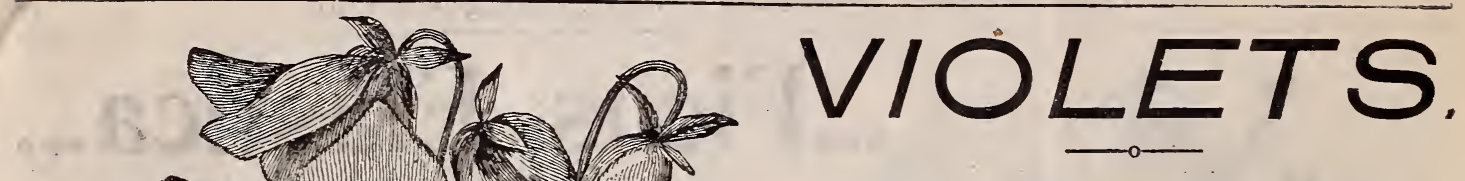

\section{Single Violet-Princess of Wales.}

This variety is far ahead of any other single Violet known. Of hardy, vigorous growth, the plants are wonderfully free-flowering, with stems from ten to twelve inches long; large green leaves of a thick, leathery texture. The grand single flowers, of a true violet color that does not fade, are round, symmetrical form. almost as large as pansies, and of the richest, most delicious fra. grance. So large and circular are the flowers that some blooms will cover a silver dollar. Price, two and one-half inch pots, 40 cents per dozen; $\$ 3$ per hundred.

\section{Single Violet-California.}

This beautiful Violet has created a decided sensation. It was raised in Colifornia where it was cutivated by the hundreds of arres as cut flowers. Buyers prefer it to all others. It is entirely hardy and of the richest dark blue and very fragrant. Price, two and one-half inch pots, 40 cents per dozen; $\$ 3$ per hundred.

\section{Double Violet-Marie Louise.}

Bold, fine flowers, very fragrant and very prolific. The color is of a dark blue, flnwers double. This is the vorite double blue. Price, $50 \mathrm{c}$ per dozen; $\$ 3$ per hundred.

\section{Eranthemum Pulchellum.}

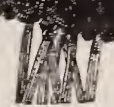

Princess of Wales.

A pretty plant of soreading habit. Blooms early in the s?: $\mathbf{n}_{\mathrm{w}}$; flowers scllow, brll. shaped, and very fagrant. Price, 5 cents each; 50 cents pcr dozen.

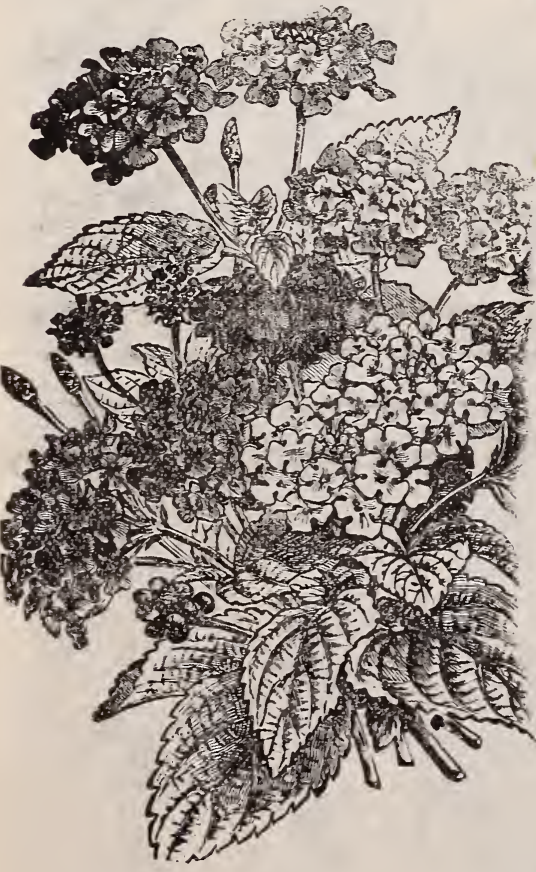

Lantanas.

The plant produces lovely, deep-hlue flowers very freely from Christ mas to March. It is of $\mathrm{i} \rightarrow$ easint culture, requiring but little care, and grows in nice, bushy shape, with many side branches, each of which is it will become a popular plant. Price, $60 \mathrm{c}$ per dozen; $\$ 4$ per hundred.

\section{Manettia Bicolor.}

A rupid and beautiful new climber. The flowers are from an inch to an inch and a half in length, of the most intense scarlet, shading in to flame, tinped with bright golden yellow, and are covered with a thick scarlet muss. This varietr must not be confounded with the old Manettia Cordifolia, as it is far superior to the old variety Price. E0: per dozen; $\$ 3$ ver hundred.

\section{Lantanas.}

Price, 50c per dozea; $\$ 3$ per bundred.

Alba Perfect3-Pure white. compact habit.

Don Calmut-Flowers lilac: orange center.

Harket?'s Perfection - Foliag, variagated wilh yellew flowers liliac.

$\Gamma^{\prime} u i$ is d'0-Flowers small; pus $\theta$ briot y ellow.

Micharl Schmidt-Flowers fri:u aud o :irkling: of 3 brilliant $\mathrm{y}^{\circ} 11 . \cdot \mathrm{w}$, passing in to a pur te veruwion.

Monfect Light lilac, wi h a pinkish e+nt. $r$ : a $1 \mathrm{ru}_{1}$ : bi color variet $z$; slaperb.

Francienne-A be ant if $n$ low-gr.swing rari.ty, with large flowers of a delighitul clear lemon tiut.

Javoir-Largn, pninted, foliage: white fliower, of the largest Fiz": ereamy'white, passing 10 the purest "hite.

Weeping Lantanas.

Thigrinnt las a most prace. ful, droming h:ihit, grows very rituidly and blıms c’ntinually sumner an $1 \mathrm{~W} \cdot \mathrm{n}$ ter, producing J'irge clustirrs of flowers of the $m n-t$ delicate lil , cor rnav nink, foliage a beatiful dark gre. n. Price, 60c per dozen; 44 per hun: $60 \mathrm{c}$ dred.

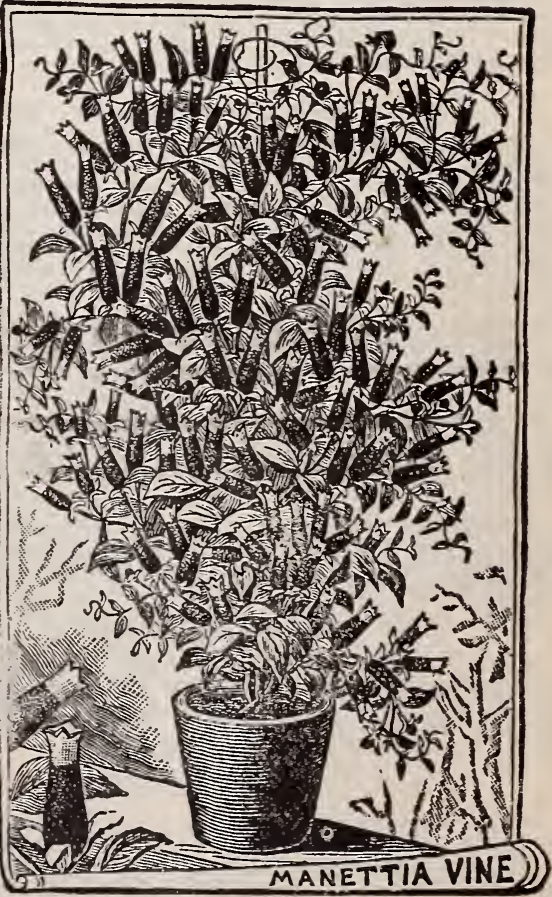




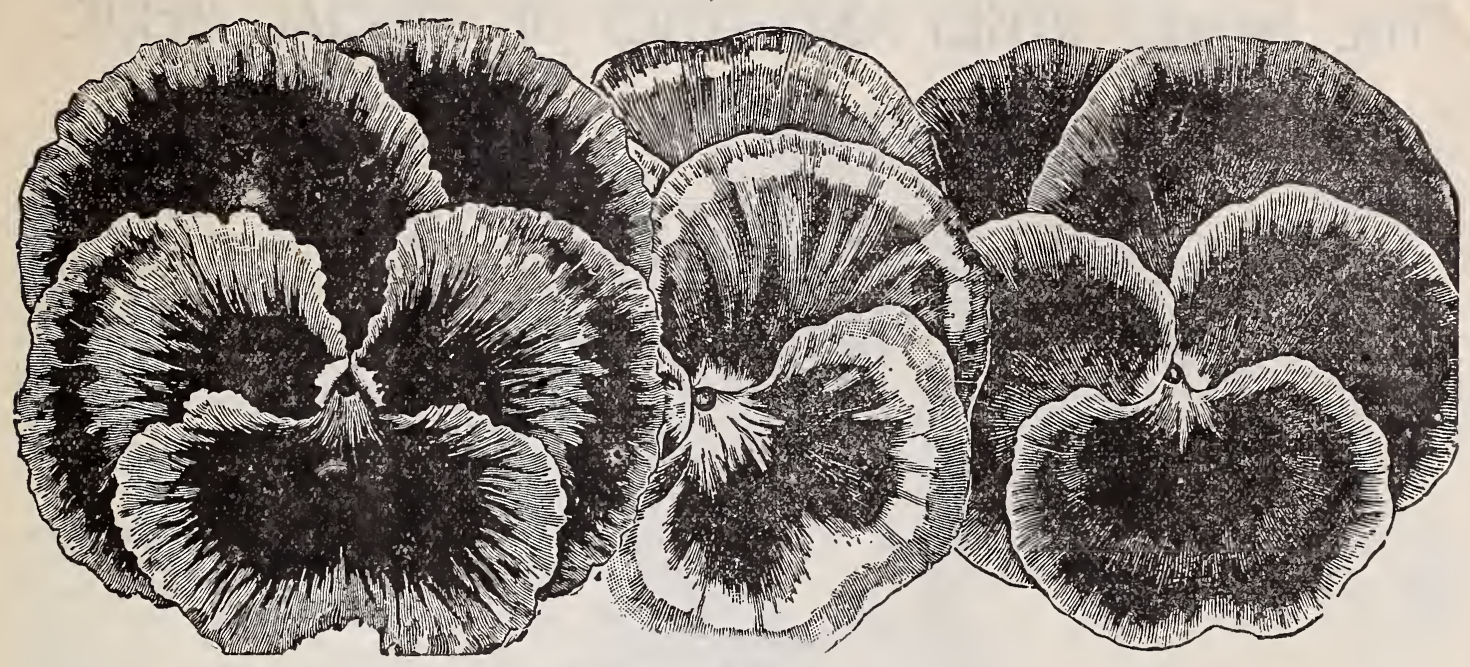

McGregor's New Mammoth Pansy.

McGregor's New Mammoth Pansy-A splendid strain of Panises, being a mixture of such celebrated vrieties as Bugnot, Trimardeau and Cassier. They are fine transplanted plants. Price, 75 cents per hundred; $\$ 5.00$ per thousand.

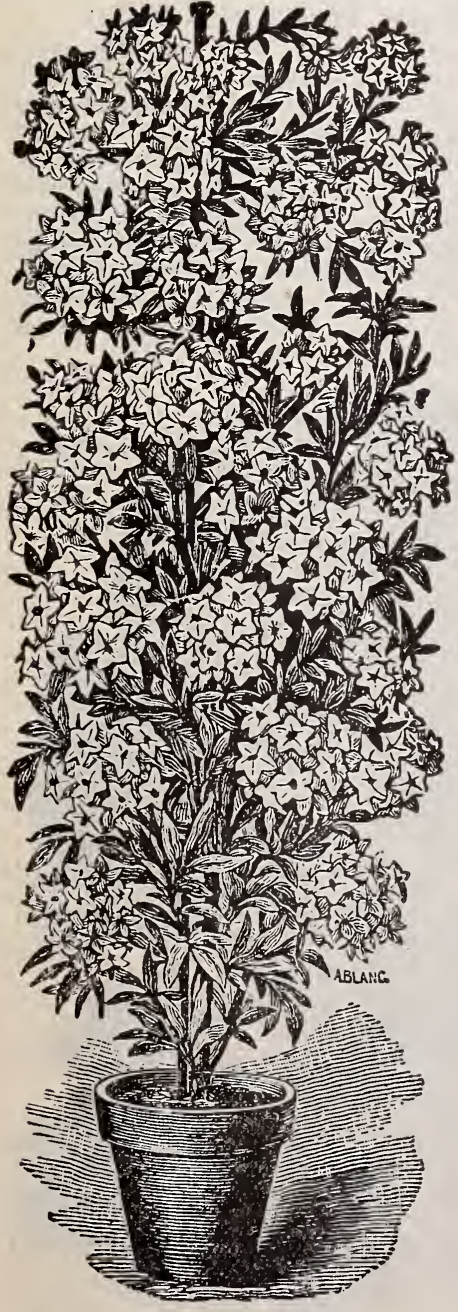

Solanum Jasminoides Grandiflorum.

\section{VINCA MAJOR==VARIEGATA.}

A beautiful variegated trailing plant, admirably adapter for hanging baskets and vases. The leaves are a glossy green, broadly margined a creamy-white: flowers blue. Price, 50c per dozen: $\$ 3$ per hundred, from 4-inch pots, field grown. Strong vines, $75 \mathrm{c}$ per dozen; $\$ 6$ per hundred.

\section{IVY--German or Parlor.}

Price, 40 cents per dozen; $\$ 3$ per hundred.

.jkania Scandens-A strong growing climber, with green foliage, stitable for large baskets and vase

Senecio Scandens-(New German, or Parlor Ivy.) A more rapid or succulent kind, well adapted for covering trel'is work quickly or trailing in the parlor: lesves glossy.green and flowers yellow, in clusters.

\section{OTHONNA--(Grassifolia.)}

Resembles the Sedums in growth and foliage: flowers bright yellnw. produced very freely. A fine plant for basket or vase. Price, $40 \mathrm{c}$ per dozen: \$: sar hundred.

\section{SALVIA SPLENDENS, or FLOWERING SA. TE.}

Cne of the finest of Fall-blooming plants, being completely covered to Artumn with long spikes of scarlet flowers, remaining in bloom until cut duwn by the trost. Price, $40 \mathrm{c}$ per dozen; $\$ 3$ por hundred.

\section{Solanum Jasminoides Grandiflorum.}

$\Delta$ beautiful plant of climbing hahit, attain. ing a height of three to five feet, but can be grown in bush form. Its flowers are starghapt d and borne in clusters, large, pare white, with a violet tinge on back of petals and on the buda In pots it is a cuntinuous bloomer both Summer and Winter; but its greatest value is for out-door culture trained against a wall or trellis. Price, $40 \mathrm{c}$ per dozen; $\$ 3$ per hundred. The Beautiful House Plant,

\section{SANBEVERIA ZEALAMICA.}

This beautiful house plant is well arlapted for the decoration of sitting rnoms, balls, t tc. as it stands dust ar d neglect of watr.rirg wit' impunity. The leaves, as shown in iliustration, grows to a length of three to four feet, and are beautifully striped cross- $\pi \mathrm{i} \rho$, with broad, white variegatiuns on a dark green ground It is a rare and b. autiful nlant $u$ hich shonld be abundanti \% grown fur positiuns out of the reach of sunlight, where other plants will not thrive. When you consider that it can be placed in any nosition in any $r^{n} n m$ and do well, its great usefulness is at onre anparent. It has a singilar beanty f',r decorative purposes whjeh other plants dis gnt, possess, and is uceful both Winter and Summer. The beautv of its leaves and the handsome snike of flowers it produces makes it on of the most desiranle plants known. Price,50c per dozen; $\$ 4$ per I undred,
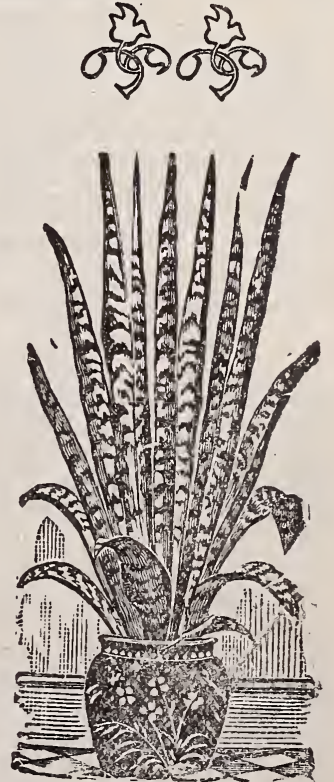

Sanseveria Zealanica. 


\section{THE NEWER ROSES AND ROSES OF SPECIAL MERIT.}

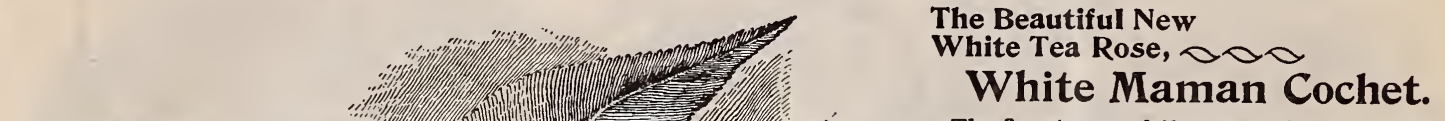

The finest rose of the year. Like its parent, the growth is vigorous, with rich, healthy foliage, producing large, fine flowers of the purest white; in fact, it is an exact counterpart of the beautiful Maman Cochet, and all who have tried it pronounce it the finest bedding Tea Rose in existence. We would advise all who love choice roses to plant at least one of this beautiful new rose. Price, 50 cents per dozen; \$4 per hundred.

\section{New Tea Rose,}

\section{J. B. VARRONE.}

A fine grower, flowers very large and double, with high center, opening from long buds. Color a soft China rose, changing to bright, deep carmine of even shading. An extra good Rose and very sweet. Much superior to Luciole, which it greatly favors, but of a better growth and much freer in blooming qualities. A grand new Rose. Price, 6 cents each; 50 cents per dozen; $\$ 4$ per hundred.

Forcing Rose, THE BRIDE:

This is decidedly the most beautiful white Tea Rose. It is a sport from Catharine Mermet, with which it is identical in growth and shape of flowers. The flowers are very large and double, on long, stiff stems, of fine texture and substance, and last a long time in a fresh state after being cut, making it one of the best va. rieties for corsage wcar or bouquets. During the extreme hot weather it becomes a pinkishwhite, at other times a beautiful pure white. Price, 6 cents each; 50 cents per dozen; $\$ 3$ per hundred.

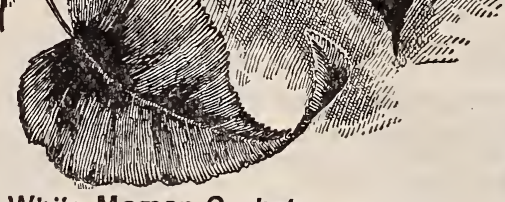

White Maman Cochet.

New Tea Rose, GEN. ROBT. E. LEE.

(Introducers' description.) This is the first Rose we have introduced, and we are sure it will please all who try it It ls in color an orange-yellow, after the color of La Capucine, only richer and better. It is a good grower, has elegant, long buds, borne on long stems, and will produce more buds than any other Rose we know of. It forces easily, being at its best in mid-Winter. There is no variety that will compa " $\theta$ with it in all the qualities that go to make up

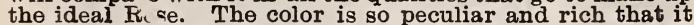
attracts atte tion wherever seen. Price, 6 cents each; 50 cents perdozel \$3 per hundred.

\section{New Tea Rose, MISS WENN.}

This charmin एariety is noticed at once for its exquisite color, whick eems entirely distinct from almost all other Roses of our a quaintance. We can call it a clear coral-pink, a most no 1 and distinct shade of color very difficult to describe. $\theta$ French call it China pink. It is certainly a very bcautit color, and full and exquisitely Tea scented. Price, 6 cente each; 50 cents per dozen; $\$ 4$ per hundred.

\section{Crimson Forcing Rose, METEOR.}

A velvety red ever-bloomes of the deepest glowing crimson. As fine as a Hybrid; filver of medium size, very double, and petals slightly recuering, A beautiful open Rose, a free bloomer and promising well as a pot Rose. It has no tinge of violet or purple to mas "its beauty. It prom. ises to be a reliable ever-bloomer, free srom bad qualities. The best rich red Rose that was ever iw tranduced for florists' use. The usual demand for this forcing \& $<$ se has caused us to grow them in large quantity, and we affer them in two sizes. Nice, strong two-and-a-half inch pots, 6 ents each; 50 cents perdozen; \$4 per hundred.

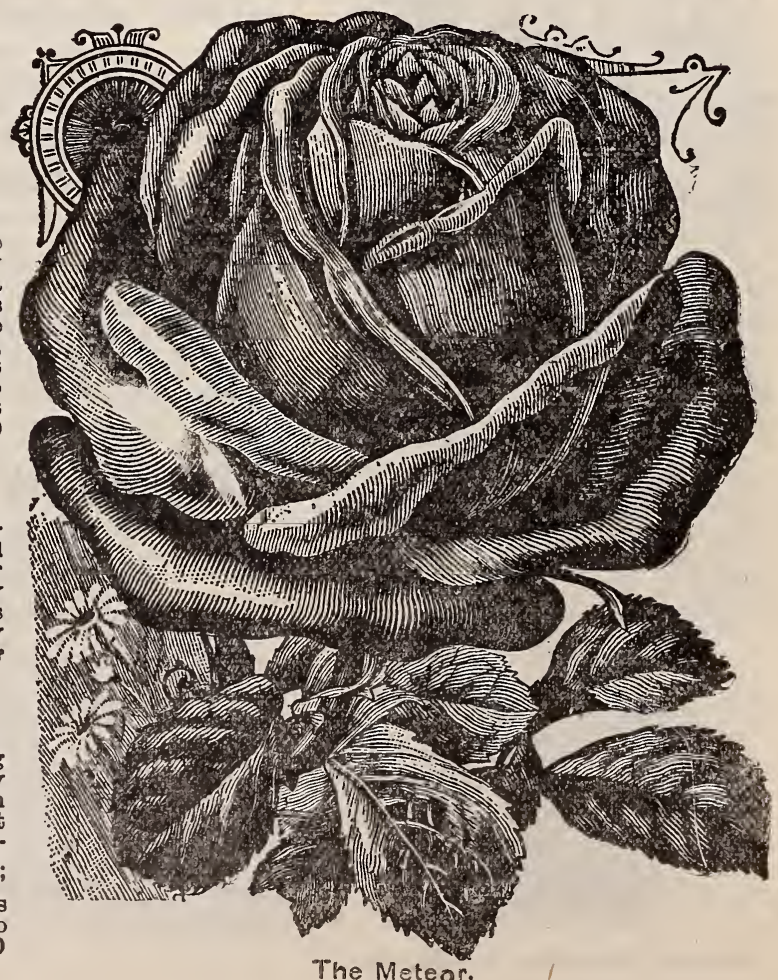

The Meteor. 


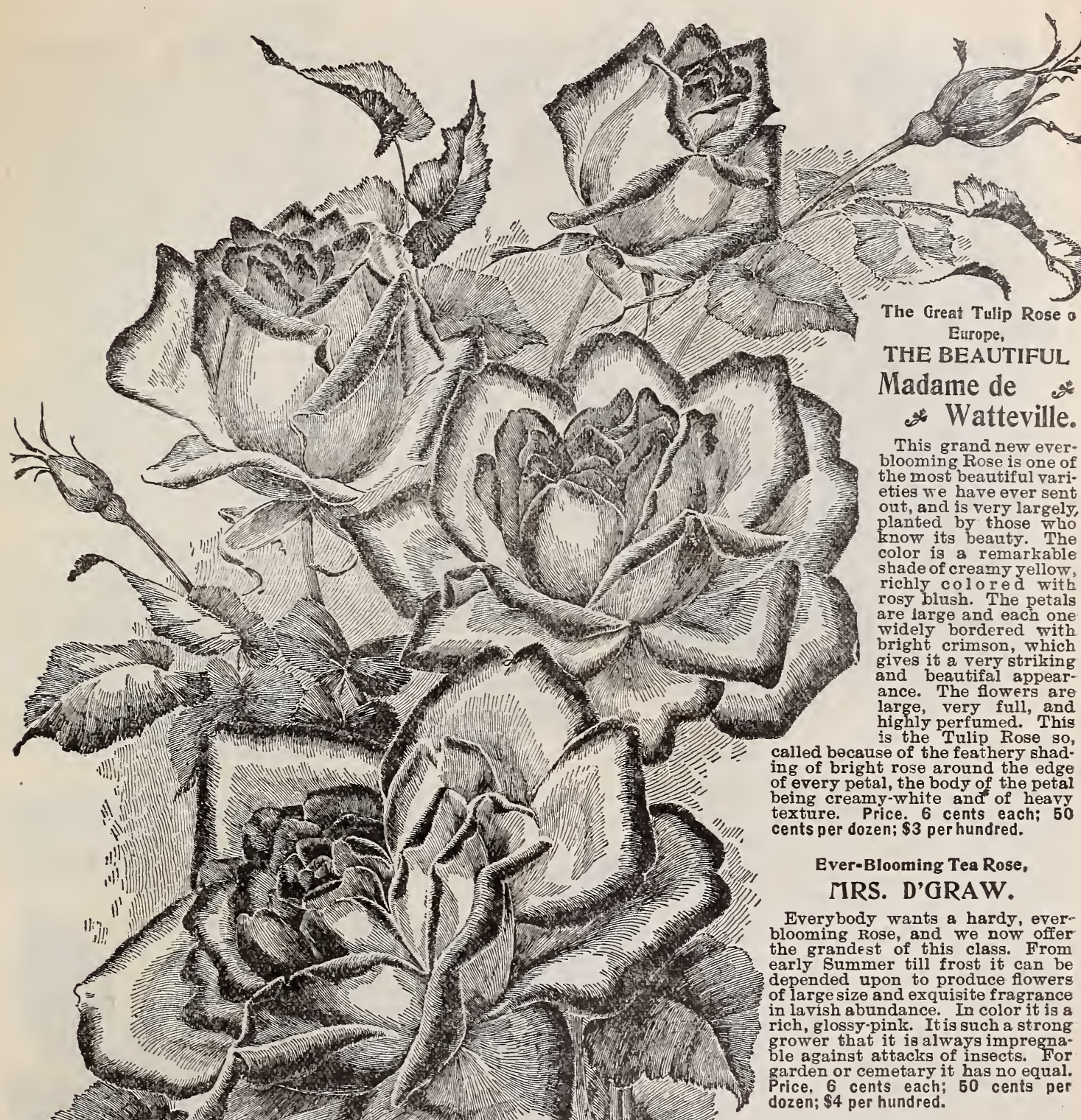

Tea Rose,

SNOWFLAKE.

It is a lovely new white Tea; the froest flowering Rose we have ever seen. The Rose was introduced by C. Straus \& Co., of Washing ton, D. C., and by them grown in large quantities for cul tow Rose they grow; that they had counted one hundred and fifty-three buds and flowers on one plant in a single day, and the nlant less than a year old. Price, 6 cents each; 50 cents per dozen; $\$ 3$ per hundred.

Madame de Watteville. (The Tulip Rose.)

New Tea Rose, MADAME ELI LAMBERT.

$A$ beautiful new Tea Rose. Flowers extra large, fine globular form, very full and well built up. Color is somewhat in the way of Madame de Watteville, but deeper, rich, creamy white, faintly tinted with pale, golden-y ellow, and exquisitely bordered and shaded with soft, rosy flesh, exceedingly beautiful and very sweet, petals large and of good substance, constant and profuse bloomer, strong, vigorous and healthy grower-in short, a magnificet Rose in every way. Price, 50 cents per dozen; \$4 per hundred.

\section{New Forcing Rose, MAID OP HONOR.}

(The Brighter Bridesmaid.) Advertised as Miss Clara Barton. This grand sport from Bridesmaid originated with the Hoffmeisters of Ohio. They say of it; "After rigid tests, during the last two years, we are able to state-first. That its color is a rich, glowing pink, darker than Bridesmaid. Second, That it is an excellent keeper, and sells over the counter better than Bridesmaid. Third, That it is a most prolific bloomer, with all perfeet buds:" Price, 75 cents per dozen; $\$ 5$ per hundred. 


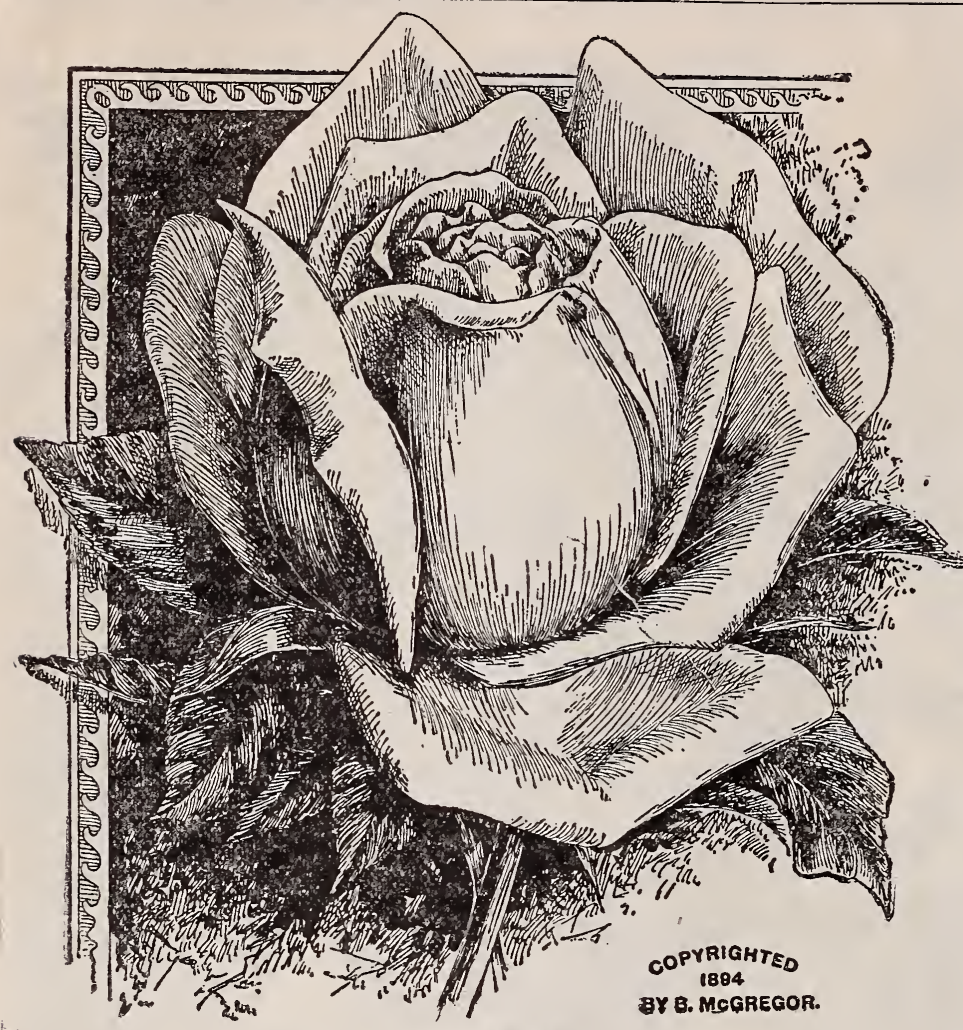

Grand New Velvety Rose,

\section{..Climbing Meteor.}

All who know "General Jack" will call to mind its beautiful, high-colored, rich, velvety-red buds and flowers. Climbing Meteor is the acme of all red Climbing Roses. It is a free, persistent will make a growth of from ten to fifteen feet in a season; in bloom all the time, as it is a true ever-bloomer. We do not hes itate to place it at the head of the list of all Roses for Summer blooming, as it will make a strong growth and literally loaded with its deep, rich, red flowers all the time. Its flowers are much lar Meteor and are richer in color. It is just the Rose to train up the verandas or around windows where its great beauty will show up to good advantage. Price, 50c per dozen; \$3 per 100 .

New Tea Rose, MURIEL GRAHA K.

This superb Rose is from that favorite variety Catherine Mermet, and is perfectly distinct in color from any thing ex tant, which is a pale cream, faintly blush. ed rose. The habit of growth is similar to its parent. Sent out by Alexander \& Sons, Belfast, Ireland, who consider it one of their best introductions. Well worth our best recommendation. Price, $50 \mathrm{c}$ per dozen; $\$ 4$ per 100 .

New Tea Rose, ENCHANTRESS.

This is beyond question one of the best of recent European introductions. We have given it a trial, and find it to be of un usual merit. It blooms with astonishing freedom, bearing its large, globular flow: ers in immen se clusters; it is as free bloom. ing as any Rose in our collection. The color is creamy-white slightly tinged with buff in the center; vigorous growth; fine foliage and highly valuable; both in pots for late Autumn and Winter blooming at well as for general planting in the open ground during Summer. Price, 50c per dozen; $\$ 4$ per 100.

Helen Gambier.

New Tea Rose, Helen Gambier-Of medium gize, very full and of varying colors, from salmon rose to coppery rose, of ten of a haudsome saffron hue, becoming lighter as the flowers open. Goes under the name of Klondyke This we consider very valuable; will become one of our standard bedding Prose Try it, Price, 50 per doz; $\$ 4$ per 100.

New Tea Rose, Mme. Abel Chatenay-(PernetDucher.) This promises to become great Rose. It is a fair grower and a free bloomer. Flowers of medium size, rosy carmine with darker shadings. Full, double, and of splendid substance. Price, 50c per dozen; $\$ 4$ per 100

New Tea Rose, Sunset-A grand variety. The flowers are of large size, fine, full form, very double and deliciously perfumed; the color is a remarkable shade of rich goldencolor is a renty tinged and shaded with amer, ruddy-copper. Intensely beautiful dark, rumbling in color a splendid "After. and resembling in color a splendid "Afterglow." It is a constant and prof

New Cllmbing Rose, Empress of China-This is a new Climbing Rose of the greatest excellence. It was brought to this country by cellence It wrom China, who says of it that a gentleman from China, who says is loaded it commences to bloom in May, and is loaded with its elegant blooms until December. Think of it! There is no other Rose like that will bloom for so no blimbing Roses, been a great om once and then are done. But that the boos a Rose that blooms continuhere we have a Rose over seven months of the year. Color shell pink. It is perfectly hardy, and is a continuous grower. Price, $50 c$ perdozen: $\$ 3$ per 100.

New Rose, Henry M. Stanley-This grand, new, ever-blooming Rose was raised from Madame Lambert and Countess Riza du Parc, and named in honor of the great African explorer, and is recommended as a charming variety of unusual beauty and permanent value. The color is a rare shade of amber rose, delicately tinged with apricot-yellow toward the center. Reverse of cot-yellow towarf-rose. The flowers are of petals clear buff-rose. The finwely formed, good substance, extra large, finely formed, dozen; es por 100
New Tea Rose, MAURICE ROUVIER.

Very full and exceedingly sweet; the color is bright pink ish rose, elegantly tinted with shades of buff, prettily veined with deep shining crimson, while many of the petals have a wide border of silvery white, which gives the flower a lighter effect than the color would indicate. It is a good, strong grower and most prolific bloomer, well worthy of high com mendation. Price, 50c per dozen; \$3 per 100.

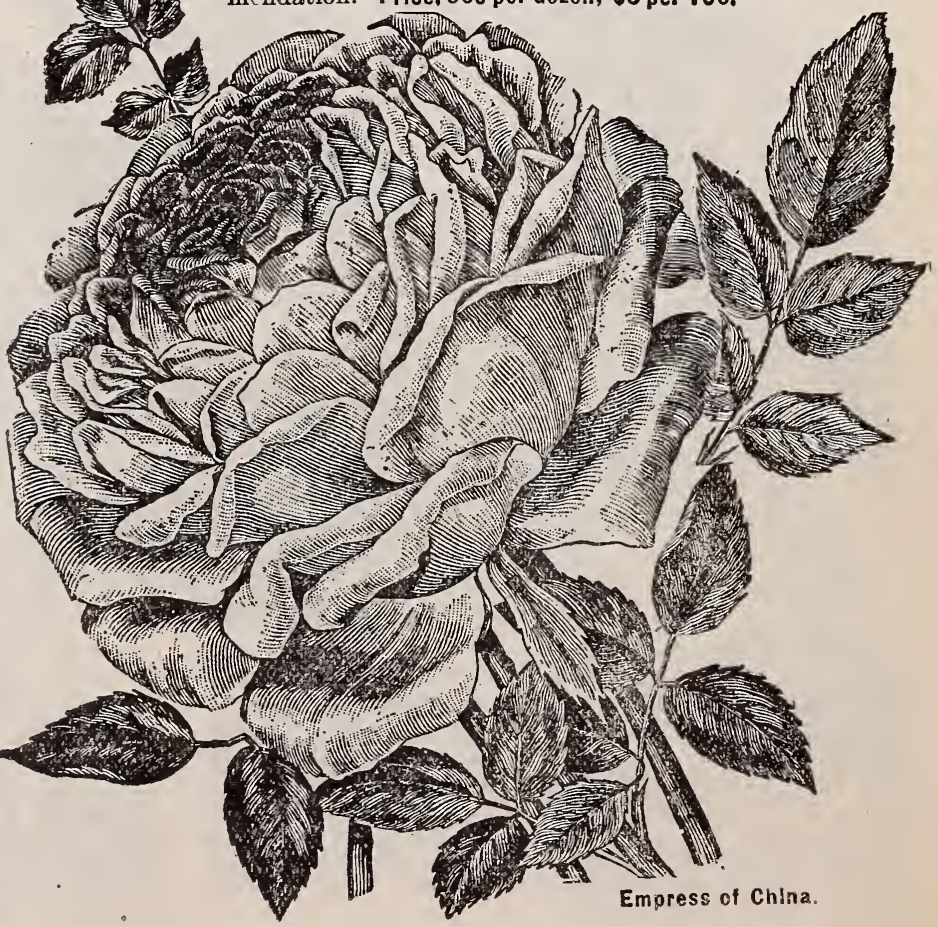




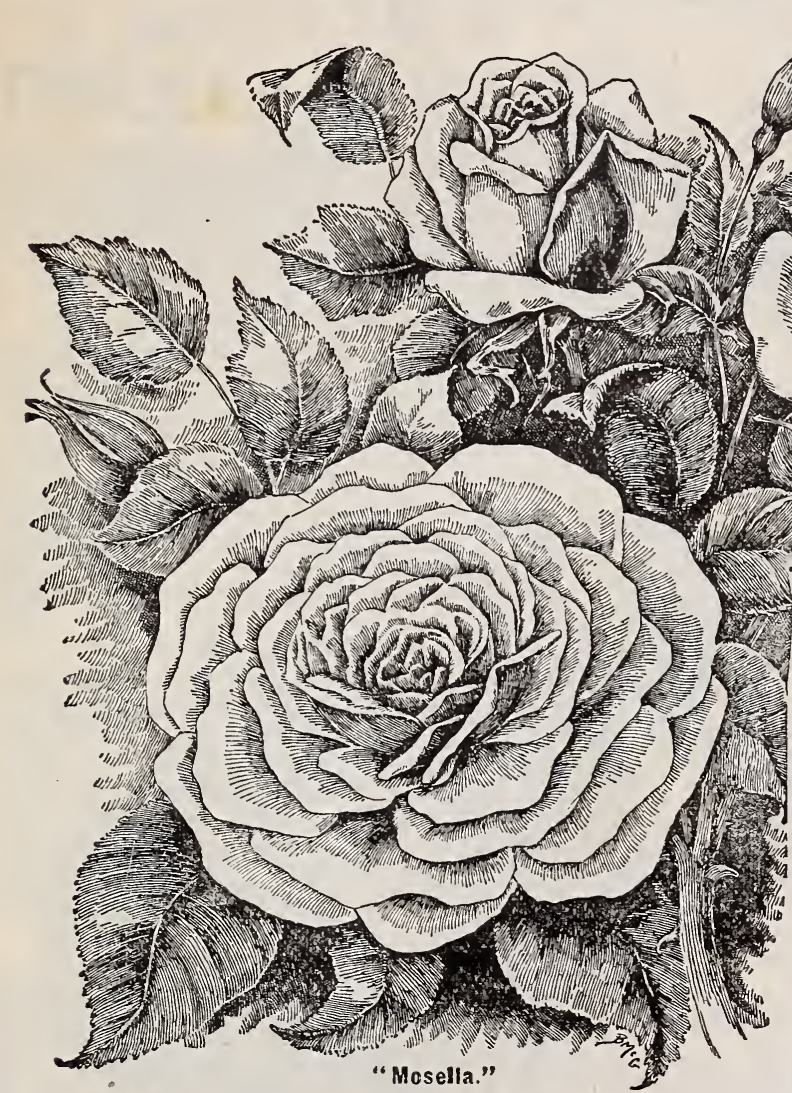

\section{LEONIE OSTERRIETH, or WHITE SOUPERT. . .}

We have given this Rose an extended trial, and believe there is no better white Rose grówn. The buds are of a good size and flower full and double, and deliciously fragrant. Pure porcelain white, vith deep center. In freedom of bloom this charming variety rivals the Polyanthas. Price, 50 cents per dozen; $\$ 3$ per hundred.

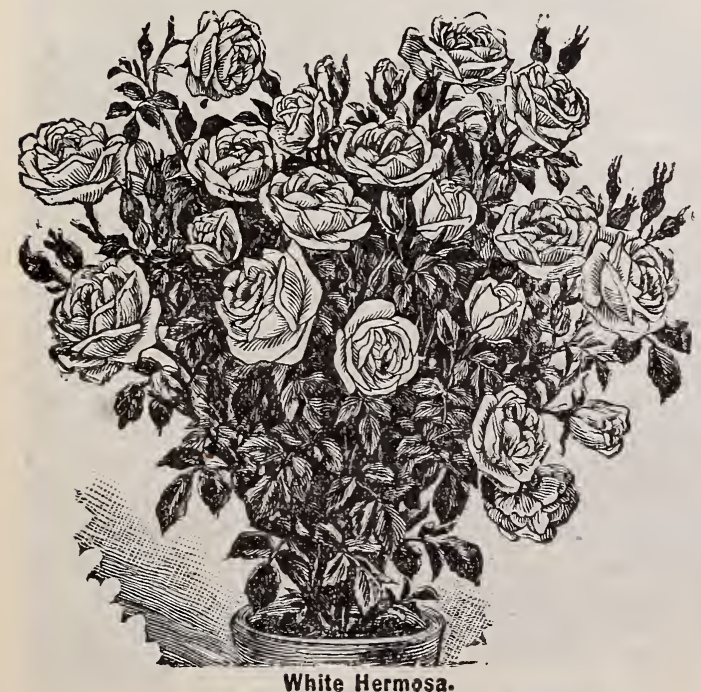

This bright new Rose is a very free flowering variety, much resembling Hermosa but more double and flowering more freely it shows the Polyantha blood in the full cluster of bloom, and it will make a handsome contrast, bedded or grown with the $\mathrm{C}$. Soupert. I he flowers are not quite so large, full and handsome as our original Soupert, but fill a place because of their brightness and freedom. The habit of the plant is almost identical with C. Soupert. Price, $50 \mathrm{c}$ per dozen; $\$ 3$ per hundred.

NEW TEA ROSE, THE QUEEN.

A most charming Tea Rose; the offspring of that fine old Rose, Souvenir d'un Amie, whose many good qualities it seem to possess in a remarkable degree. It is purs snow-white, makes good, finely formed buds; is quite full, showing the center bot slightly. Price, $6 \mathrm{c}$ each; 50c per dozen; $\$ 4$ per hundred.

TEA ROSE, PROFESSOR CANIVIAT.

Vigorous in growth and free in bloom. Flower double and of good form; of the color of Souvenir Therese Levet. Price, $6 c$ each; $50 \mathrm{c}$ per dozen; $\$ 3$ per hundred.

THE FINE EVER-BLOOMER,

MARIE LAMBERT, or WHITE HERMOSA.

Pure white. It has been called the White Hermosa, as it re. sembles Hermosa in form and freedom of bloom, and is quite as valuable; for, though no claim has been made for it as a fancy Rose, its persistence in bloom will make it a very popular white variety for bedding or for pots. This Rose is fast becoming popular, as there is no better white Rose. It is the finest blooming white Rose we offer. Price, $6 \mathrm{c}$ each; $50 \mathrm{c}$ per dozen; $\$ 3$ per hundred. 


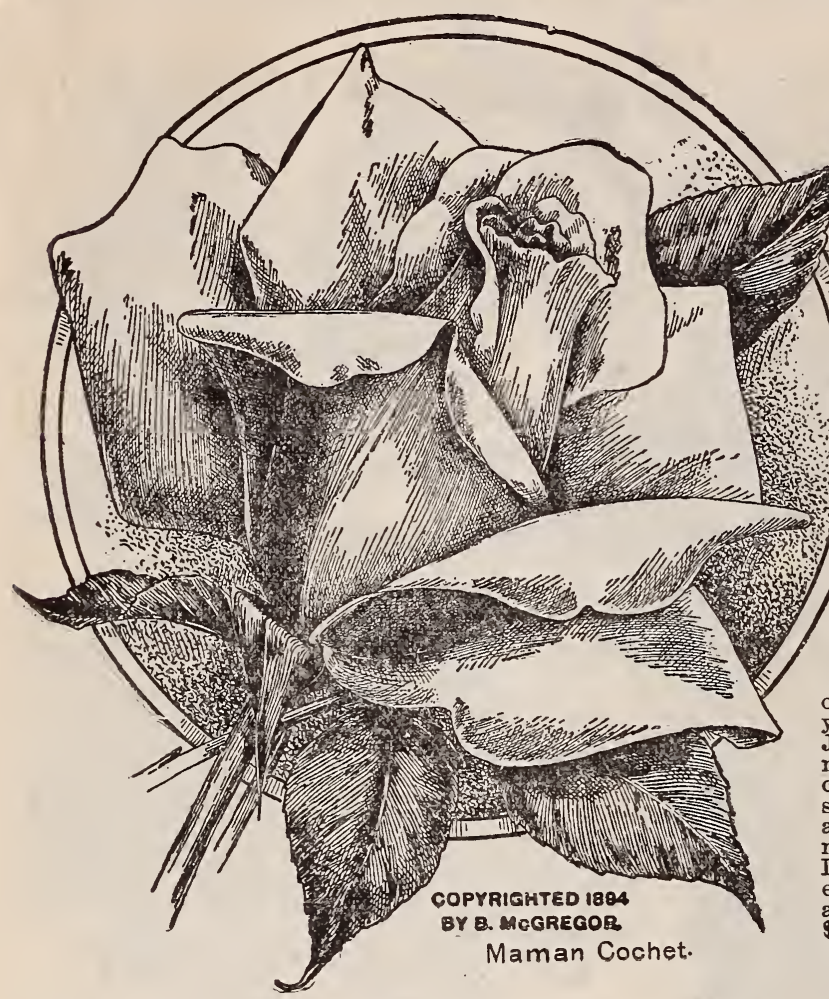

The Magnificent Rose, ETOILE DE LYON.

This magnificent Tea Rose is a rich golden-yellow, a strong, healthy and vigorous grower, immense bloomer, bearing flowers and buds early and late. The flowers are very deep, rich and full; excellent substance; very sweet. Surely one of the very best and most beautiful yellow Tea Roses for general planting ever introduced. Remarkably hardy, both as to heat and cold, frequently standing the Winters here uninjured in open ground without protection, and blooming nicely all through the hottest part of the Summer. Price, $50 \mathrm{c}$ per dozen; $\$ 3$ per hundred.

Crimson Rose, Princess Sagan-Flowers of this variety are the richest orimson of any Rose in our vast collection. A single bud or blossom will on of an hose in Will catch the eye at a great distance, so brillant is the eollor. Velvet Rose." It is as free in blooming as Bon Silene. Price, 50c per dozen; $\$ 3$ per hundred.

New Tea Rose, Golden Gate-This magnificent Rose is a cross between the old greatly admired varieties, Safrano and Cornelia Cook, and while combining the good qualities of both is vastly more beautiful than either. It is a strong, healthy grower, excellent for both bedding and house culture. Produces a profusion of long, poin ted buds, opening to very large double Roses of creamy-white, beautifully tinted with soft yellow at the base of the broad petals, which are ex. quisitely bordered with clear rose. We heartily recommend it. Price, 50c per dozen; \$4 per hundred.

New Hybrid Tea Rose, President Carnot-It is a Rose of the largest size, beautiful both in bud and open flower. The buds come on long, stiff stems, in clusters of from 6 to 12. Each individual flower stands out distinct on its stem. No crowding as in the case of so many Roses that bloom in clusters. The color is distinct and novel, a lovely fawn, shading to pearl. It of ten measures 5 to 6 inches in diameter. We have no hesitancy in saying that this charming Rose will become as popular as La France, as it has all the good qualities of that Rose, and at the same time is distinct

Climbing Perle Des Jardins-Few Roses have as firm a hold in popular favor and are so highly prized by the professional and amateur Rose growers alike as the Perle des Jardins. It is not only admirably adapted for forcing, but thrives well in the open air, blooming freely in either case. Its large, full, well-formed, golden-yellow flowers, borne on stiff stems, makes this variety especially desirable for bouquets and artistic floral decorations, while the dark and glaucous foliage of the plant furnishes an excellent setting for the fragrant delicate hued blossoms. Hardy South. Price, 50c per dozen; $\$ 4$ per hundred.

\section{* NEW TEA ROSE *} MAMAN COCHET

One of the best new Roses. The growth is vigorous, with rich, healthy foliage. The extra large flowers are produced on long stems; are very double, and the buds and half expanded flowers are simply exquisite in their graceful form, delicate color and rich fragrance. The color is deep rose pink. Price, $60 \mathrm{c}$ per dozen; $\$ 3$ per hundred.

\section{Tea Rose, PERLE DES JARDINS.}

Without doubt the finest Rose in cultivation. Canary or golden-yellow flowers and beautifully formed. Handsome in every stage of development, from the smallest bud to the open flower. Price, $6 \mathrm{c}$ each; $50 \mathrm{c}$ per dozen; $\$ 4$ per hundred.

\section{GUSTAVE NADAUD.}

(Soupert \& Notting.) A free branching grower, with large, double flowers. The outside petals are large and rounded, giving it an exquisite cup shape. Color, vermilion, with clear touches of carmine-lake, and soft pink center. Price, $6 c$ each; 60c per dozen; \$4 per hundred.

\section{LA FRANCE.}

We have always given this the first place-the Queen of Roses. Accounts come to us from all quarters every zear describing the great profusion of its bloom from une until frost, and extolling its fragrance and immense size. It is of superb form, and double as a Rose can be. No variety can surpass it in delicate coloringsilvery-rose shades, with pink. It has a satin sheen over all its petals. It is most universally regarded as the most useful of Roses, for it is hardy beyond question. t blooms continuously. The flower is large, finely built endures for a great length of time, is exquisitely colored and fragrant in the highest degree. Price, $50 \mathrm{c}$ per dozen; $\$ 4$ per hundred.

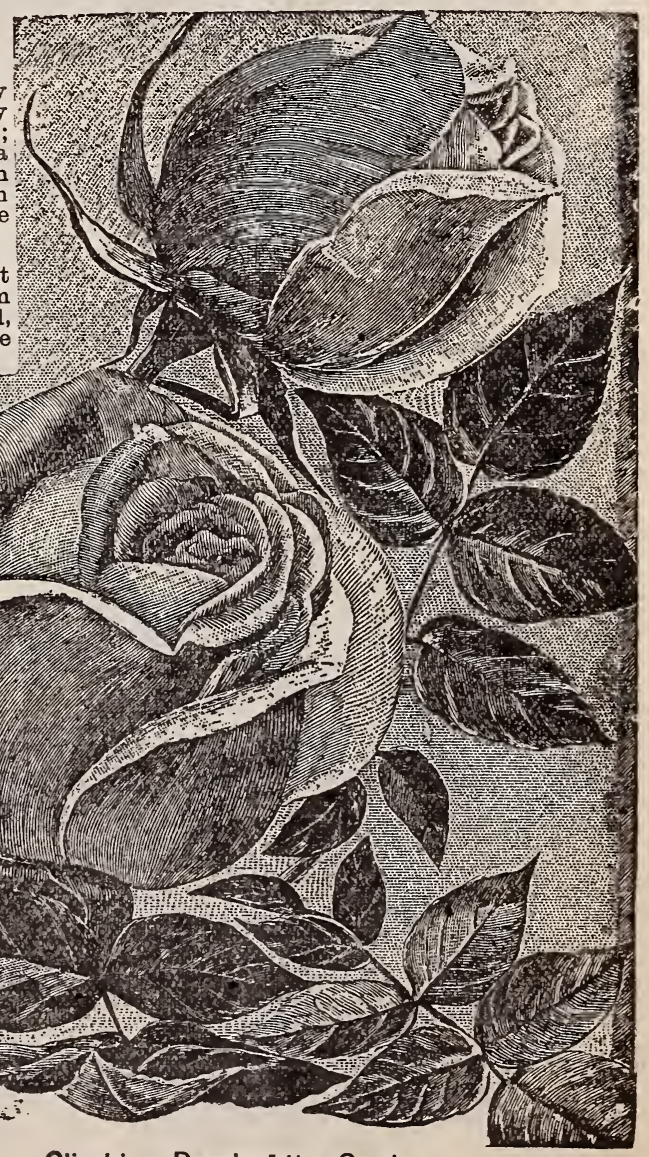

Climbing Pearl of the Garden. 


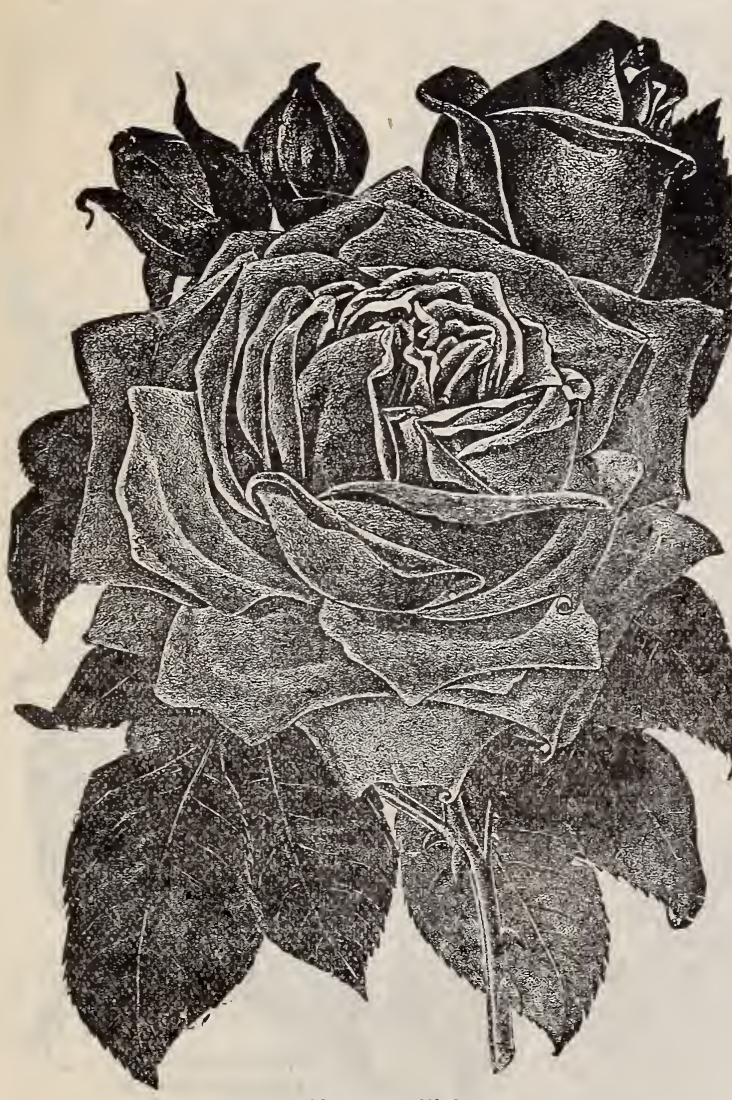

Marechal Niel.

New Rose...

\section{THE RAINBOW.}

This new Rose from California was awarded a silver cup by the State Floral Society. Color a lovely shade of deep corai pink, striped mottled in most unique manner with intense crimson, elegantly colored with rich goldenamber at the center of base of petals; makes beautiful buds: flowers extra large, sweet and of great depth and substance. Price, 50c per dozen; $\$ 3$ per 100.

\section{The Fine Pink Forcing Rose...}

\section{- CATHERINE MERMET.}

One of the finest Roses grown. Its name is the synonym for all that is delicats and beautiful. Its buds are inimitable, faultless in form and charming in their every shade of color, from the purest silvery-rose to the exquisite combining of yellow and rose, which lllumines the base of the petals. It is, beyond doubt. the Rose of all Roses, and ycu should not fail to have a Mermet in your collection. Price, 50 cents por dozen; $\$ 3$ per 100

\section{Forcing Rose...}

\section{BRIDESMAID.}

A new Rose. A sport from that old standard, Catherine Mermet. This variety retained all the good gualities of the parent, besides adding charms not possessed by the sweet Catherine. All know that Catherine Mermet takes precedence as a pink Rose. More plants of it are cultivated by the an a teur and more cut blooms are sold by the flower dealer of it than any pink Rose. Why? Because the bud is of exquisite shape and contour, so solid and firm, and the stems are so solid and stiff that no and Rose will compare with it in keeping qualities after bein cut. It has, though, with all these good qualities, a serious defect; namely, "nff color." This is more noticeable in dark, cloudy weather, but it is true of the Rose at all times. Now, this is why the Bridesmaid will supersede the Mermet. It is about two shades deeper in color, just enough to make it bright: and it is the same color all the time, under every condition of weather and surroundings. Price, $50 \mathrm{c}$ perdozen; $\$ 3$ per 100 .

\section{Che Superb Inarechal Diel}

The most popular of all. A Rose so lamous as to really require no description. Its magnificent colden-yellow buds are worn the world over; they illustrate the globular form in its last perfection, and are almost massive in dimensions. The reports from Southern growers tell of single plants showing one and two thousand blooms of Marechal Niel at a time. It is almost universally held to be the finest climber for indoors or out, where the climate admits of its cultiva. tion. Price, 50 c per dozen; $\$ 3$ per 100.

New Tea Rose, GOLDEN GATE

This magnificent Rose is a cross between the old greatly admired varieties, Safrano and Cornelia Cook, and while combining the good qualities of both is vastly more beautiful than either. It is a strong, healthy grower, excellent for both bedding and house culture. Produces a profusion of long, pointed buds, opening to very large double Roses of creamy. white, beautifully tinted with sofi yellow at the base of the broad petals, which are exquisitely bordered with clear rose. We heartily recommend it. Price, $50 \mathrm{c}$ per dozen; 4 per 100.

Fine Crimson Tea Rose, PAPA GONTIER

A grand red Tea, of fine crimson shade and silken texture (as distinct from velvety texture). The bud is fine size and graceful form, and you would never suspect from it that the rose is only semi-double. Extremelv free, both in growth and bloom. Very long and beautifully leaved stems can be cut, the foliage very dark and heavy. One of the best, and a perfect bedder. Price, $50 \mathrm{c}$ per dozen; $\$ 4$ per 100. IIARIE VANHOUTTE.

Of a fine, faultless, straw-yellow color, with the outer petals washed and outlined with $\mathrm{a}$ bright rosy-crimson; occasionally the whole flower will be sufitused with light pink. It grows vigorously, blooms profusely, and is most deliciously scented; in cold weather it almost changes color, taking on gorgeous crimson tints. A beautiful and superb Rose. Price, 50c per dozen; $\$ 3$ per 100 .

MADAME WELCHE.

An extra fine variety, very large, double, and of beautiful rounded form, a soft, pale yellow, sometimes cream, with short inner petals of glowing orange and copper. Not to be forgotten if once seen. Price, 50c per dozen; $\$ 3$ per 1 CO.

New Tea Rose, MAURICE ROUVIER.

Flowers of enormous size and quite double; splendid form; color a soft tender rose, shaded and variegated with red. Price. $50 \mathrm{c}$ per dozen- $\$ 3$ per 100.

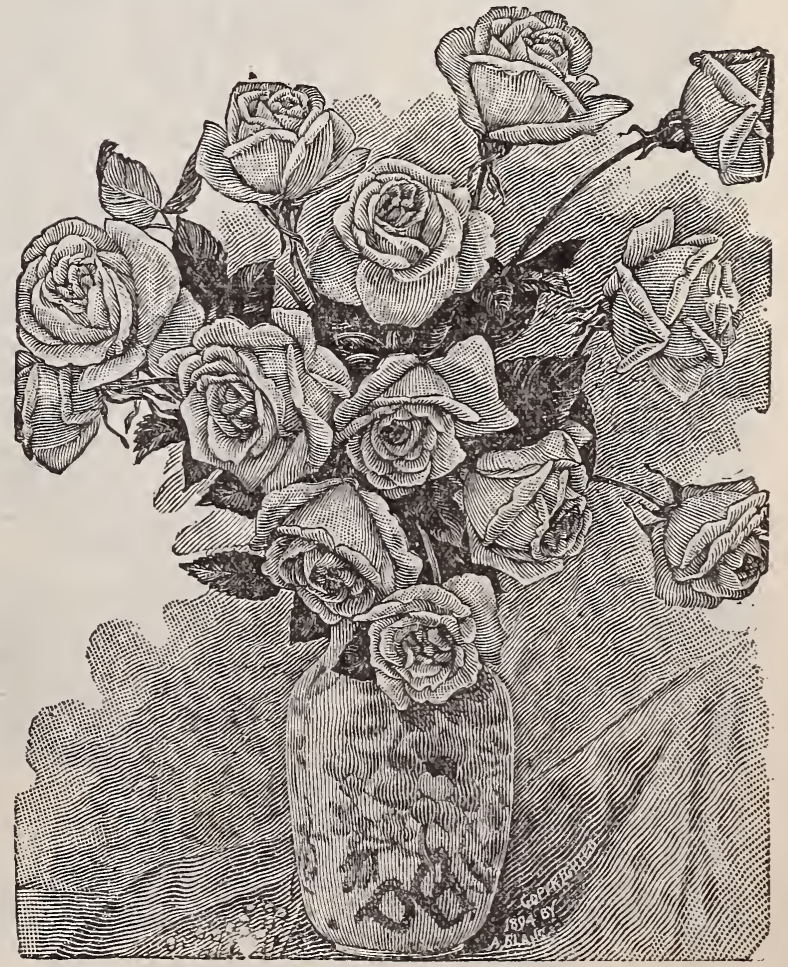

A Vase of Bridesmaid Roses. 


\section{MANDA'S WICHURIANA HYBRIDS. . .}

MTANDA'S TRIUMPH.

This grand Rose is of free growth, luxuriant foliage, and produces large clusters of double. pure white flowers, beautifully imbricated and well formed, two inches in diameter and sweetly scented, Price, $50 \mathrm{c}$ per dozen; $\$ 3$ perhundred.

\section{SOUTH ORANGE PERFECTION,}

(Manda.) This is a gem, growing freely close to the ground, and having multitudes of the most perfectly formed double flowers, about one and a half inches in diameter, soft blush-pink at the tips, changing to white. It lasts a long time in perfection. Price, $50 \mathrm{c}$ per dozen; \$3 per hundred.

\section{PINK ROAMER.}

(Manda.) This is without question a hybrid between the Sweet brier, and carries these characteristics in bloom, while the growth which is very important, and the luxurious foliage, partake more of theWichuriana. The single flowers, which are produced in close heads, are nearly two inches in diameter, bright, rich pink, with almosta white center, which lightens up the orange-read stamens. Price, $60 \mathrm{c}$ per dozen; $\$ 3$ per hundred.

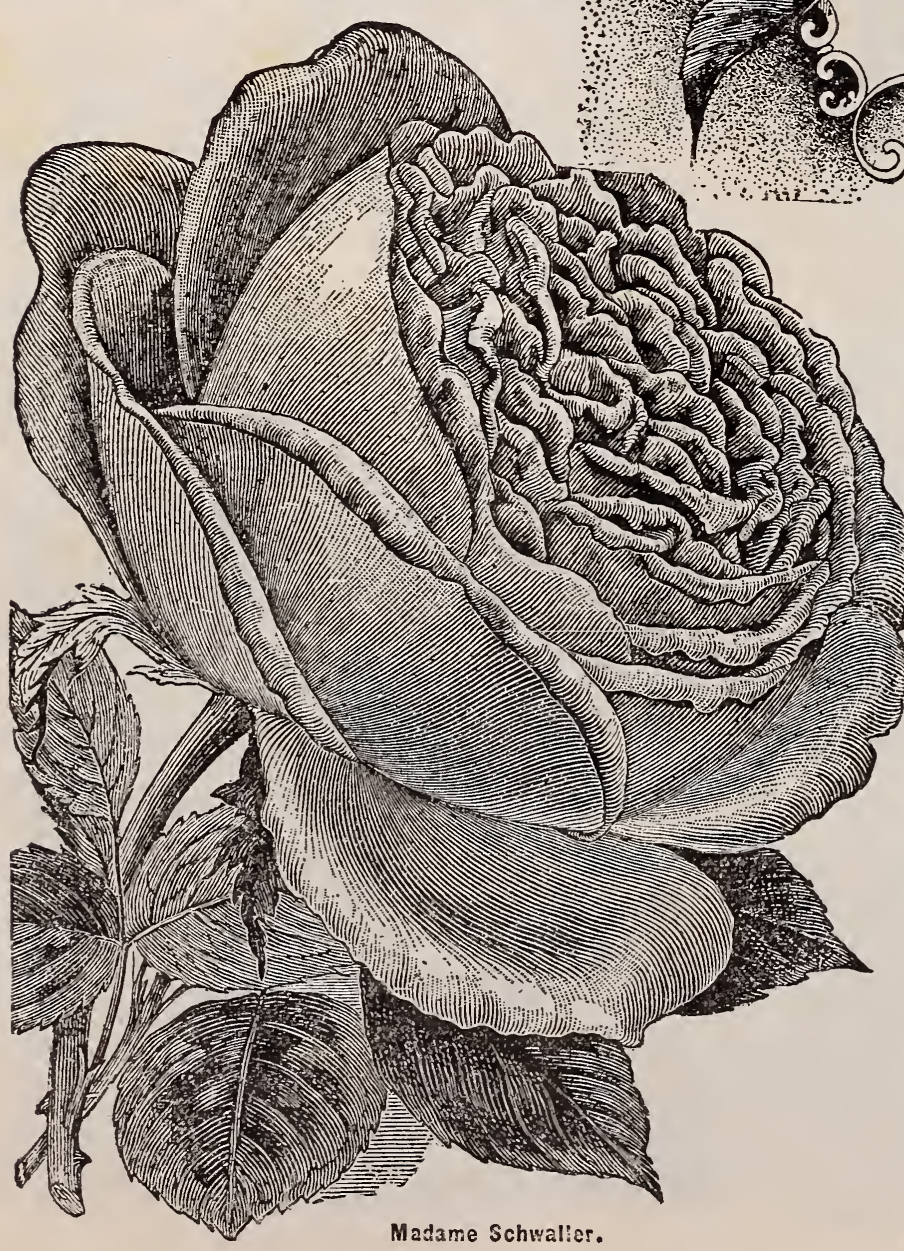

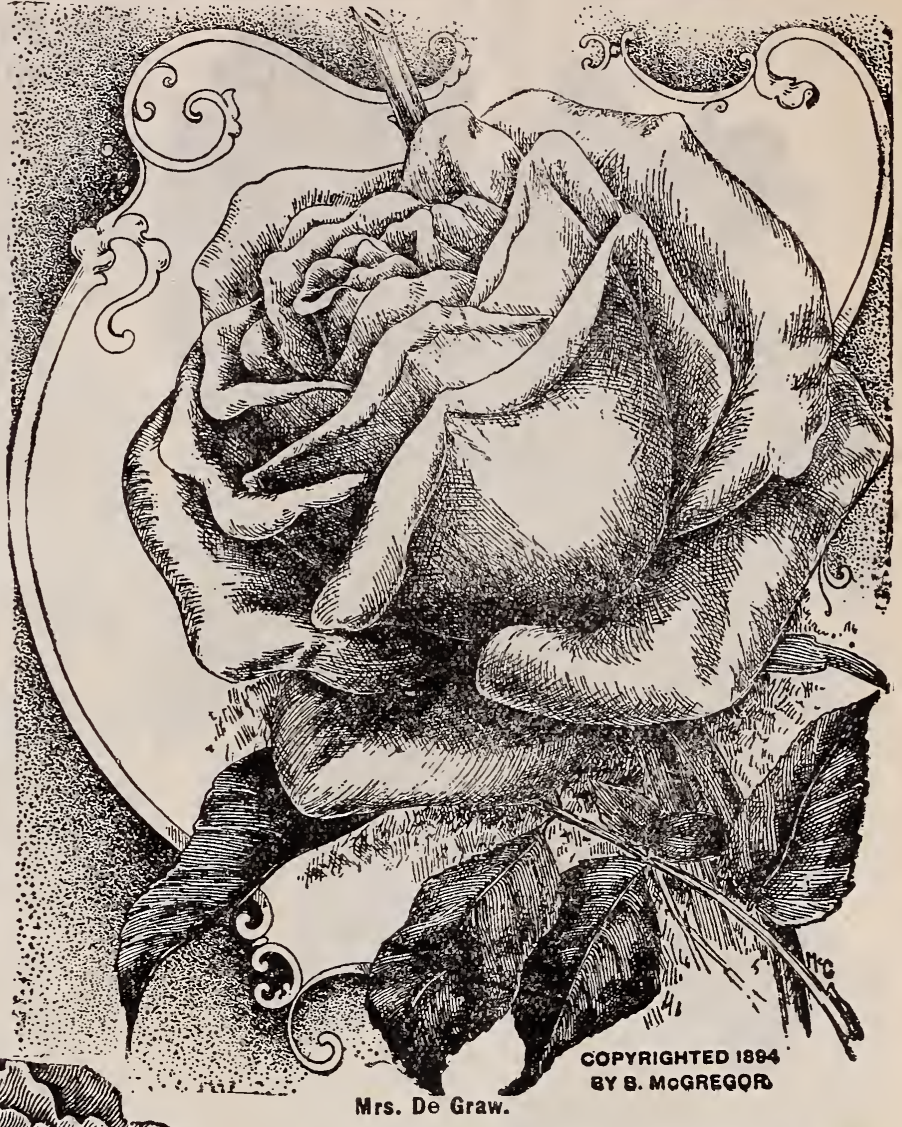

Hardy Ever-Blooming Rose, MRS. DoGRAW.

Everyone wants a hardy, ever-blooming Rose. From early summer until frost it may be depended upon to produce flowers in abundance. In color it is a rich glossy pink, delightfully fragrant, and is such a strong, vigorous grower that it is almost impregnable against attacks of thc insects which usually destroy some of our finest Roses; thus it is certain to be unequaled for the garden or cemetery. A Royal Rose. It is a wonderfully prolific blooming variety. Every shoot is loaded with flow. ors. Price, $50 \mathrm{c}$ per dozen; $\$ 4$ per hundred.

\section{Tea Rose, CORNELIA COOK.}

Old favorite. The buds are of immense size, borne up high on massive stems, and with their round full, heavy form carry an air of grace and dignity quite unusual. The flowers are of the clearest, snowiest white. Price, 50c per dozen; $\$ 4$ per hundred.

\section{ETOILE DE LYON.}

This is considered one of the finest yellow bedding Roses for outside planting: it is more. over, oue of the hardiest in the Tea section. It blooms freely, and evers flower is a gem. It equals Marechal Niel in size, on strong bushes. A deep chrome-yellow. A remarkable Rose, deserviag extensive culture. Price, 50c per dozen; $\$ 3$ per 100.

New Tea Rose, MME. SCHWALLER.

Like Puritan, this Rose has the strong, firm growth of the Hybrid Perpetuals, the same form and finish of flowers, being especially beautiful when full blown. It is very free in bloom, and has the fragrance of the old June Roses. The color is a brigt $t$ rosy flesh, paler at the base of the petals, and deepening at the edge. Apt to come in clusters, which are excellent for cutting. A Rose from which we hear very flattering reports from all directions. This grand Rose has more perfume than any that we offer. Try it, it is magnificent. Price, 50 c per dozen: $\$ 3$ per 100 


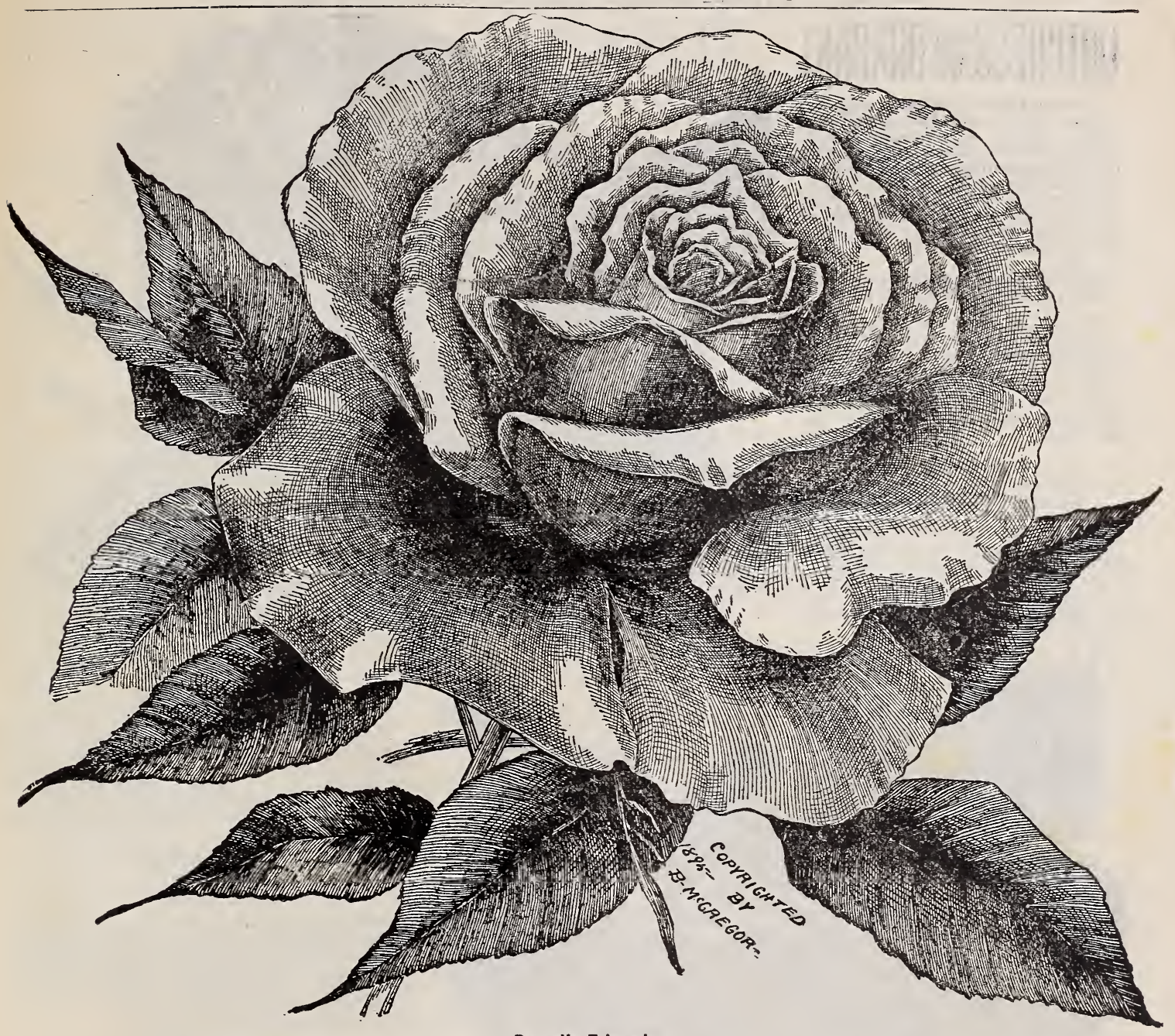

Pernet's Triumph.

The Beautiful New Rose,

\section{..Pernet's Triumph..}

The Finest All-Round Crimson Rose to Date.

Originated and sent out by Jean Pernet, one of thr most celebrated Rose growers of France, who has already given us some ver beautiful Roses, but considers this the triumph of his life (the name translated would read "Triumph of Father Pernet"), and besides his endorsement it has received the commendation of the highest European authorities, and as far as we can jndge it is well worthy of them, and promises to be one of the very finest of the Hybrid Tea class. The flowers are extra large, having broad, thick petals and long, tapering buds, with delicious Tea fragrance. Color a fine, clear magenta-red, sometimes passing to a bright crimson. Very striking and beautiful, and of such a good substance that the flowers retain their beauty for a long time. Price, $50 \mathrm{c}$ per dozen; $\$ 3$ per 100 .

\section{New Rose, MRS. ROBERT GARRETT.}

A magnificent new Rose originated by John Cook. The size is enormous; indeed, the flowers are larger than any Tea Rose we have ever seen, while the form, both in bud and full blown flower, is most artistic and beautiful. The buds are unusually long and pointed; the open flowers full and double. The color is a pleasing soft, pink, a little deeper than Daybreak Carnation, totally distinct and unlike anything jet seen in Roses. It is a strong, vigorous grower, producing its flowers on long, stiff stems. We regard this as one of the great new Roses, which will attain instant popularity as soon as its merits become known. Price, $75 \mathrm{c}$ per dozen; \$5 per 100.

\section{... THE BURBANK ROSE..}

A perfectly hardy, free flowering, ever-blooming Rose, raised by Mr. Luther Burbank, known the world over as the "Wizard of Horticulture." The only Rose which he was willing should bear his name. The Burbank is without exception the freest-flowering Rose in cultivation. The flowers are double, of fine form, nearly three inches across. The color is a deep rose-pink, shading to beautiful soft rose the center. The petals are well incurved so that the center is hidden. In September and October the outer petals change to a deep, rich carmine. The whole flower is most pleasing in its rich, graceful beauty and is delightfully fragrant. Price, 50c per dozen; $\$ 3$ per 100 .

\section{New Scarlet Rose, CLIMBING W00TON.}

This elegant new Climbing Hybrid Tea Rose is one which promises to be a prime favorite wherever introduced. Everything good that can be said of the grand Rose, Souvenir de Wooton, can be said of this Rose, and more too. The flowers are large and of a beautiful velvety-red color, and the perfume is elegant. Whether open, half open or in bud, the flowers are of fine shape. The flowers are borne at the terminus of long shoots, which render them especially good for cutting, much better, in fact, than the flowers of its parent, Souvenir de Wooton. There is always a demand for a good, hardy Climbing Tea, inasmuch as there are exceedingly few to be had. This Rose we believe to possess a rert considerable degree of hardiness, and should, with protection, stand the Winter almost anywhere. We consider this one of the best new Roses introducod for years, and as it can be planted out of doors or in, doing equally well in either place, there is no question bu that it will soon become immensely popular. Order a good plant now, so as to have the first one in your neighborhood. Price. 50 c per dozen; $\$ 3$ per 100. 


\section{DUTCHESOS REBRABANT}

A bright China Rose, with coppery. yellow center,ends of petals suffused with carmine. A charming, beauti-
ful combination of coloring, as each color blends nicely with the other. This variety ranks with the best, and is a Rose of decided merit. Free bloomer, and in size and length of buds equal to the best Teas. Price, 50 c perdozen; $\$ 3$ per 100 .

NEW TEQ ROSE, FRANGISKA PRIES.

One of the most robust growing varieties among the Teas, not climbing, but making long and sturdy shoots. Flowers medium sized; color cream white, shaded with am. ber; exceedingly free blooming. Price. 6c each: $50 c$ per dozen; \$4 per 100 .

\section{New Tea Rose,}

MADAME PHILUON GOCHET.

A very thrifty, strong-growing Tea Rose, producing cup-shaped flowers in the greatest profusion. Color rose, shaded with salmon, and suffused with a lighter shade. Price $21 / 2$-inch pots, $6 c$ each; 50 c per dozen; $\$ 4$ per 100 .
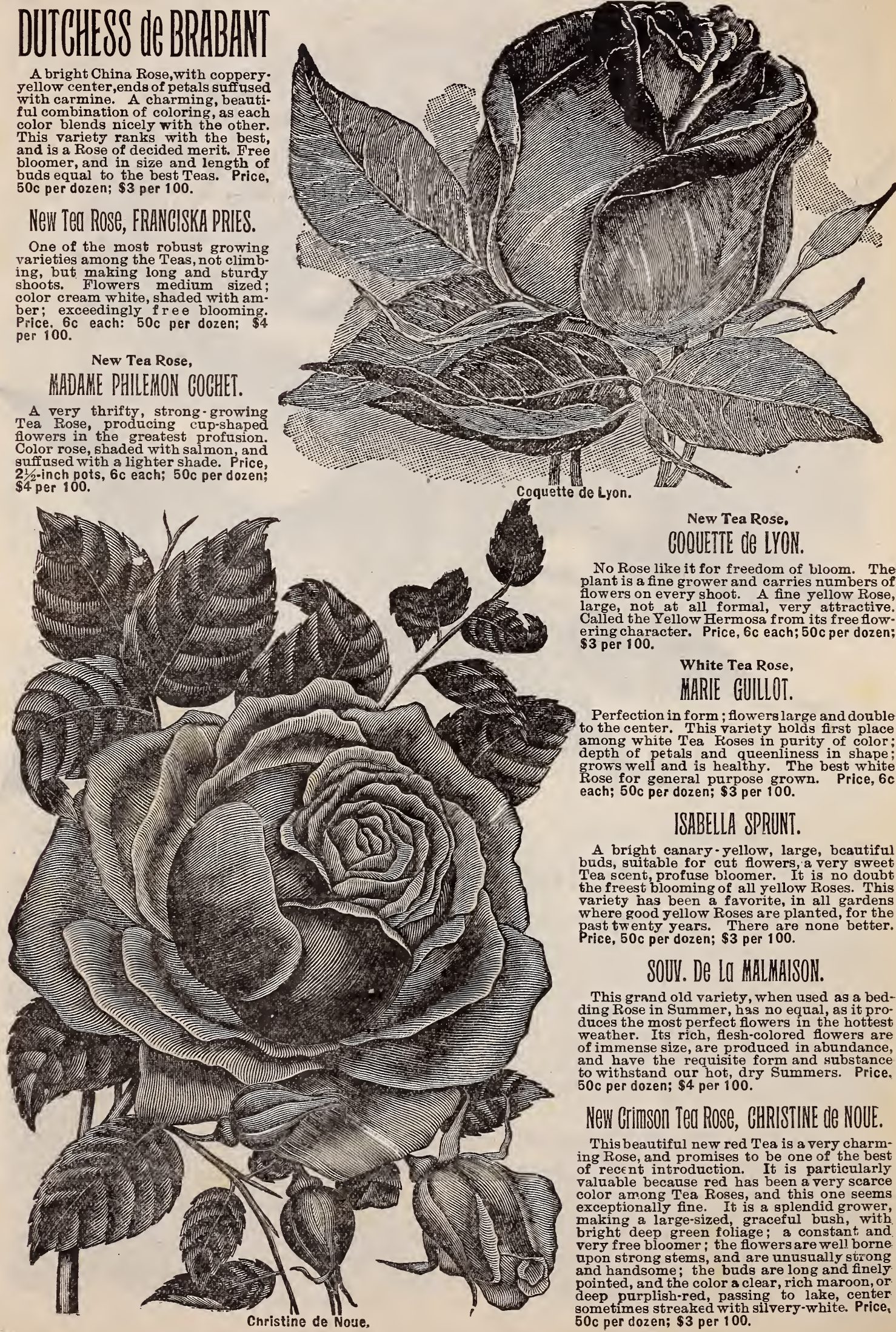

New Tea Rose, GOOILTTE de IVON.

No Rose like it for freedom of bloom. The plant is a fine grower and carries numbers of flowers on every shoot. A fine yellow Rose, large, not at all formal, very attractive. Called the Yellow Hermosa from its free flow. ering character. Price, 6c each; 50c per dozen; $\$ 3$ per 100 .

White Tea Rose,

MARIE GULLOT.

Perfection in form; flowers large and double to the center. This variety holds first place among white Tea Koses in purity of color: depth of petals and queenliness in shape ; grows well and is healthy. The best white each; 50c per dozen; $\$ 3$ per 100.

\section{ISABELLLA SPRIUNT.}

A bright canary-yellow, large, bcautiful buds, suitable for cut flowers, a very sweet Tea scent, profuse bloomer. It is no doubt the freest blooming of all yellow Roses. This variety has been a favorite, in all gardens where good yellow Roses are planted, for the past twenty years. There are

SOUV. DE LO MALMAISON.

This grand old variety, when used as a bedding Rose in Summer, has no equal, as it produces the most perfect flowers in the hottest weather. Its rich, flesh-colored flowers are of immense size, are produced in abundance, and have the requisite form and substance to withstand our hot, dry Summers. Price. 50 c per dozen; $\$ 4$ per 100 .

New Crimson Ten ROSE, CHRISTINE de NOUE.

This beautiful new red Tea is a very charming Rose, and promises to be one of the best of recent introduction. It is particularly valuable incuse red has been color among Tea Roses, and this one seems exceptionally fine. It is a splendid grower, making a large-sized, graceful bush, with bright deep green foliage; a constant and very free bloomer; the flowers are well borne upon strong stems, and are unusually strong and handsome; the buds are long and finely. pointed, and the color a clear, rich maroon, or pointed, and the color a clear, rich maroon, or sometimes streaked with silvery-white. Price, 


\section{Ever Blooming Roses.}

\section{Purchasers' Selection..}

Price, 5 Cents Each, 50 Cents per Dozen; $\$ 3$ per Hundred.

Not less than three of a kind in dozen lots, and not less than fire of a kind in hundred lots.

\section{Strictly Our Selection...}

Five of a Kind, if Desired, $\$ 2.50$ per 100 .

We also give the purchaser the privilege of mentioning the kinds he does not want.

NOTICE $=$ Parties Desiring to Purchase Large Quantities of Roses We will be Pleased to Price their List and Answer All Correspondence Promptly. ering.

ANDRE SWARTZ-A new, distinct and beautiful dark crimson velvet.

ALINE SISLEY-Beautiful shade of violet-red, fine, large pointed buds.

BON SILENE-Deep rose color, sometimes bright, rosycrimson, occasionally pale light rose.

CRIMSON BEDDER - Medium size, rich, dark, velvet. crimson.

CHARLES ROVOLI-A lovely shade of carmine.

DUTCHESS DE BRABANT-A soft, rosy-flesh, changing to deep rose.

GENERAL DE TARTAS-A brilliant carmine, deeply shaded with violet. An extra large Rose.

ISABELLA SPRUNT-This Rose is a bright canary-yellow, large and beautiful buds.

JAMES SPRUNT-Deep velvety-crimson, very double.

LUCULLUS-A fine, dark crimson. It is very double and a constant bloomer. A good Rose.

LA PRINCESS VERA-The color of this variety is a creamy rose, veined with lilac; large and full.
LA PACTOLE-A pale, sulphur-Jellow; large and full.

LA SYLPHIDE-A blush color, with a fawn center; large and double.

LOUISA DE LA RIVE-Color a soft rose blush, delicately shaded with salmon and fawn. A good Rose.

MARIE LAMBERT-(Thite Hermosa.) The flowers are medium size; color pure white. This rose will become more popular because of its blooming qualities.

MADAME BRAVY-Rich, creamy-white, with blush center; perfect form.

MADAME LOMBARD - Beautiful shade of rosy bronze, changing to salmon.

MADAME CAROLINE CUSTER - Beautiful orange relloxr, clear and distinct; fine.

PRINCESS SAGAN-Bright scarlet crimson; the flowers are medium size, semi-double and fragrant.

SOLFATERRE - Sulphur-yellow; large, double full and fragrant. A strong grower.

SOUVENIR D'UN AMIE - Fine, delicate rose, shaded with salmon.

SOUVENIR DE DAVID-Rich crimson, double, good bloomer.

WHITE DAILY-Pure white, fine bloomer; pretty bud.

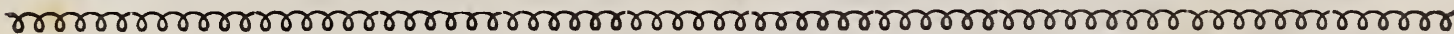

POLYANTHA

\section{ROSES \\ $\$ 3.00$ Per Hundred.}

MIGNONETTE-A lovely Fairy Rose ; full, regular flowers, perfectly double and delicately perfumed. Its color is a clear, delicate rose, with a frequent and peculiar intermingling of white.

PARQUERETTE-Flowers pure white, about one inch in diameter, flowering in clusters of from five to fifty blooms. Very full, prettily formed, resembling blossoms of the double white Primrose in profusion of bloom.

ETOILE D'OR-The flowers are medium size, very fragrant, full round form, perfectly double and borne in large clusters; color pale chrome-yellow, with rich citron-red center.

\section{HARDY CLIMBING PRAIRIE ROSES.}

Price, 5o Cents Per Dozen; $\$ 3.00$ Per Hundred.

EALTIMORE BELLE-Pale blush, variegated carmine, rose and white; very double. Flowers in beautiful clusters.

PRAIRIE QUEEN-The flowers are very large and of peculiar globular forms. Bright rosy-red, changing to.lighter as the flower opens. Of very strong, rapid growth.

MRS. GUNNEL-Soft, rosy-blush, becoming almost white; large clusters; full and double

PRIDE OF WASHINGTON - Brilliant amaranth, shaded rose center: large cluster, rery double.

TENNESSEE BELLE - Flowers bright, beautiful pink. Is more slender and graceful in growth than any of the other varieties.

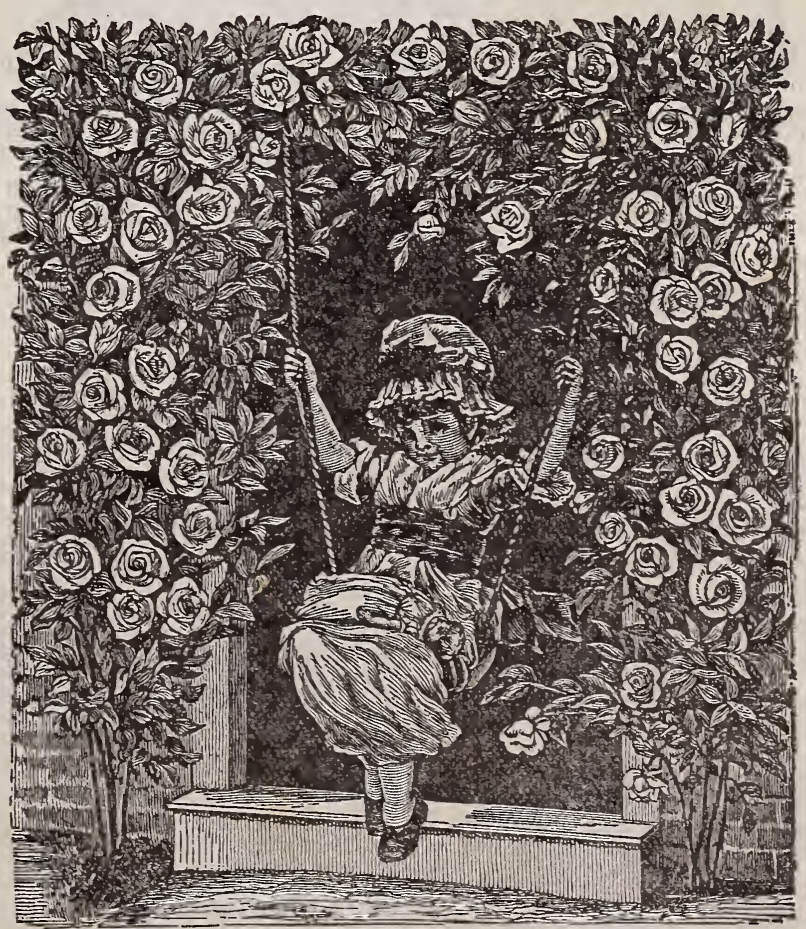




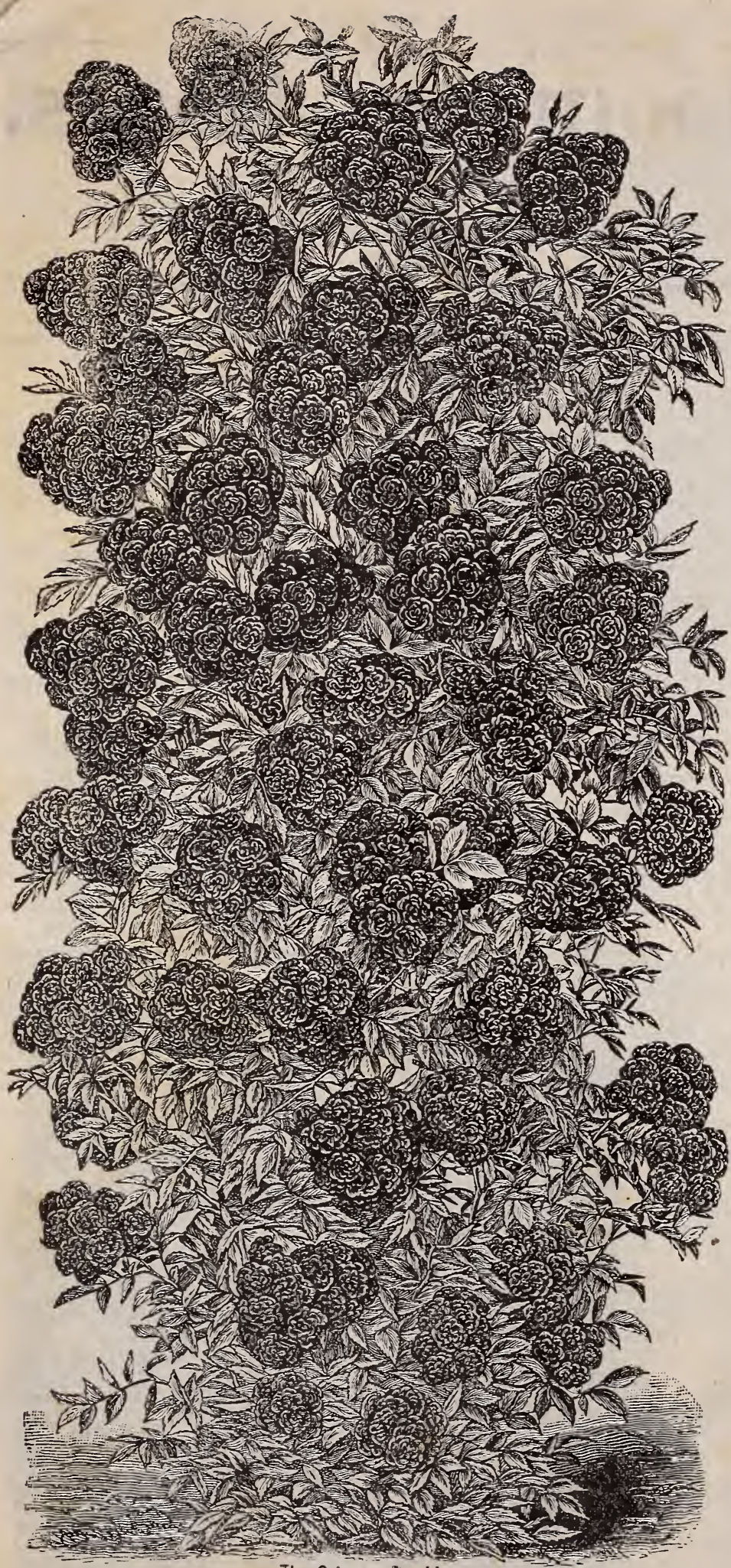

The Famous New Hardy Climbing Rose,

Crimson

\section{Rambler}

The plant is of a very vigorous growth, making shoots from eight to ten feet during the season, rendering it a charming pillar Rose. It is also magnificent in bush form, and for covering buildings, trellises, etc., it cannot be excelled. Ono of the striking characteristics of this Rose is its remarkable color, which is of the brightest crimson, which remains undimimed in the end, showing none of the objectionable purplish tint so common in crimson Roses. The flowers are produced in great pyramidal panicles, or trusses, each carrying from thirty to forty blooms, the individual flowers measuring about one to one and a half inches in diameter, and remaining perfect on the plant for upwards of two weeks with their freshness of color unimpaired. The foliage is a bright green and glossy, and contrasts finely with the bright crimson of the flowers. It is said to be exceedingly hardy, having successfully withstood the situations of two very severe winters in England. It is hardy in every latitude yet tried as far north as the lakes. As a decorative pot plant it can. not be excelled. Price, 50c per dozen; $\$ 3$ per hundred; \$25 per thousand; 4-inch pots, fine, $\$ 8.00$ per hundred.

\section{The Yellow Rambler (Aglaia)}

The advent of the Yellow Rambler marks a very important epoch in the Rose world. It was originated by the prominent Rose grower, Mr. Peter Lambart, Jears and first offered it to the public yly this last season. Its production is a great triumph in the art of hybridizing. The Yellow Rambler has been found to successfully withstand, without protection, a continued temperature of from zero to two degrees below. The flowers are borne in immense clusters, after the same manner as the Crimson Rambler, often as many as one hundred and fifty blossoms in a bunch, and the trusses have the same handsome pyramidal shape as the Crimson Rambler. The color is a decided yellow. Many Roses which are described as yellow have really only a creamy tinge, but the Yellow Rambler is very sweet-scented; habit of growth is very vigorous, well-established plants often making shoots from eight to ten feet in height in a single season. The plants do not bloom at quite so early an age as the Crimson Rambler, but as soon as well established they more than imake up for this by the magnificence of the flowers they produce. Price, $50 \mathrm{c}$ per dozen; $\$ 3$ per hundred; \$25 per thousand.

$$
\curvearrowright \prec
$$

The Fine New Climber,

\section{Climbing White Pet}

CThe Best of the White Climbers.

This is an unusually vigorous grower and a wonderfully profuse bloomer. It is remarkable for the rapidity of its growth and freedmo of bloom. The flowers are very double and full, of medium size, pure, snowy white and borne in large clusters, continuously throughout the whole season. Price, $50 \mathrm{c}$ per dozen: $\$ 3$ per hundred; $\$ 25$ per thousand; 4 -inch pots, fine. $\$ 8.00$ per hundred.

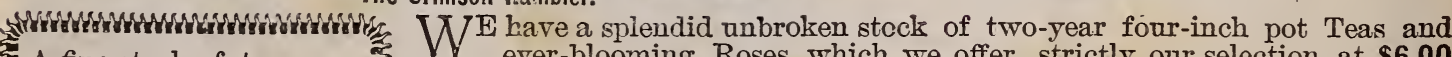
A fine stock of two-year four-inch Pot Roses. : : $\begin{aligned} & \text { per hundred. Hybrid perpetual } \\ & \text { selection, } \$ 8.00 \text { pes hundred. }\end{aligned}$
}

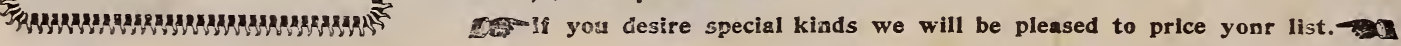

